May 2000

IMF Staff Country Report No. 00/68

\title{
Georgia: Recent Economic Developments and Selected Issues
}

This Recent Economic Developments and Selected Issues report on Georgia was prepared by a staff team of the International Monetary Fund as background documentation for the periodic consultation with this member country. As such, the views expressed in this document are those of the staff team and do not necessarily reflect the views of the Government of Georgia or the Executive Board of the IMF.

Copies of this report are available to the public from

International Monetary Fund - Publication Services

70019 th Street, N.W. • Washington, D.C. 20431

Telephone: (202) 623-7430 - Telefax: (202) 623-7201

Telex (RCA): $248331 \mathrm{IMF}$ UR

E-mail: publications@imf.org

Internet: http://www,imf.org

Price: $\$ 15.00$ a copy

\section{International Monetary Fund Washington, D.C.}





\section{INTERNATIONAL MONETARY FUND}

\section{GEORGIA}

\section{Recent Economic Developments and Selected Issues}

Prepared by Emmanuel van der Mensbrugghe, George Tsibouris, Sheila Bassett, Christopher Lane, Yuri Sobolev, Julien Hartley (all EU2), Krishna Srinivasan (PDR), Steven Barnett, and Thomas Baunsgaard (both FAD)

Approved by the European II Department

April 6, 2000

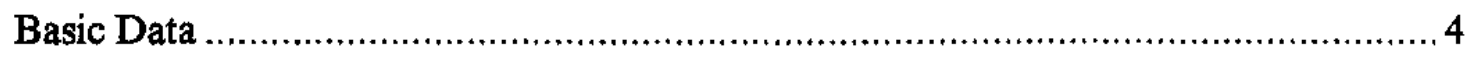

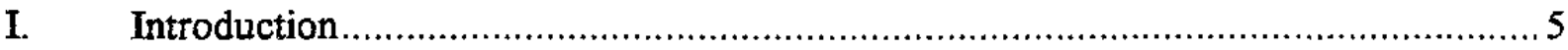

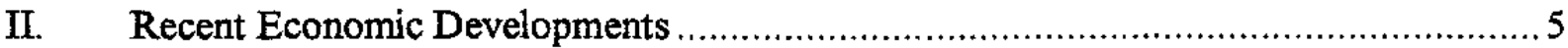

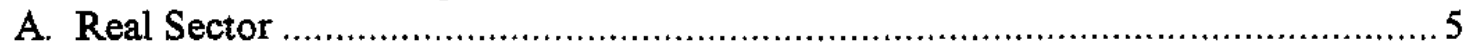

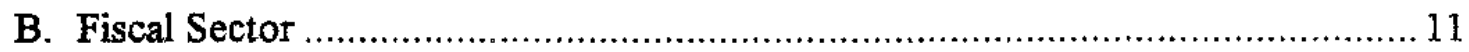

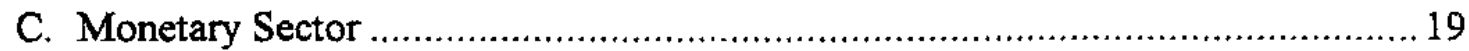

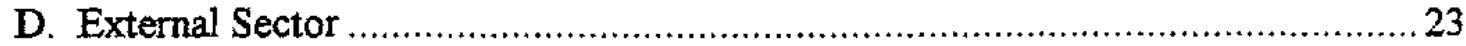

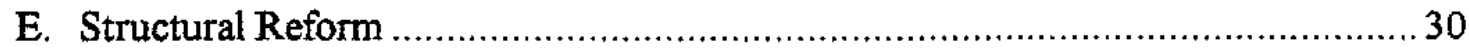

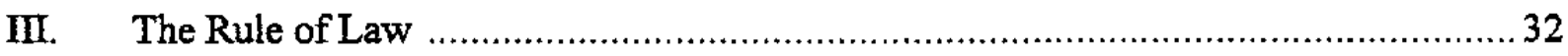

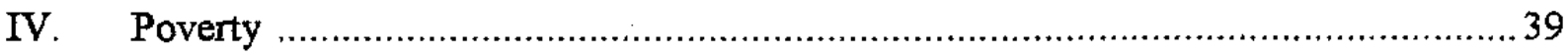

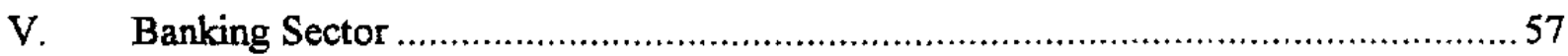

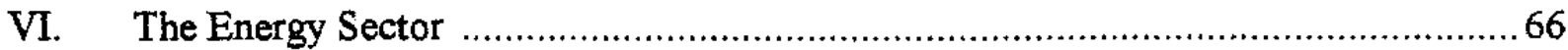

VII. Exchange, Trade and Payments Systems ………................................................ 71

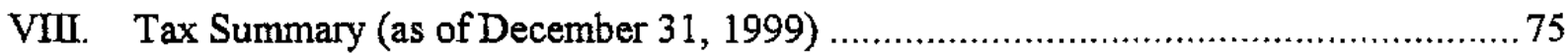

Annex

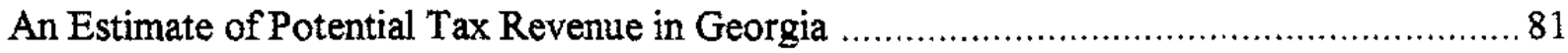




\section{Text Boxes}

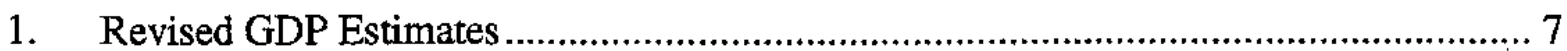

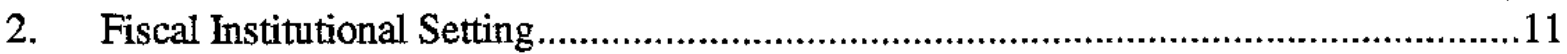

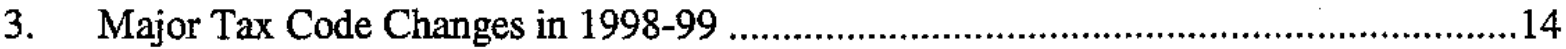

4. Legislative Steps Toward a Market Economy..............................................................35

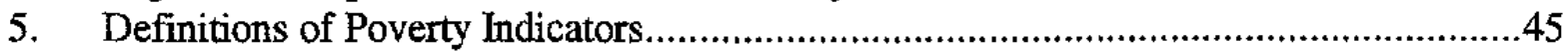

Text Tables

1. Poverty Indicators at Different Poverty Lines, 1998-99 .........................................42

2. Average Monthly Cash Income and Expenditure per Equivalent Adult in 1998-99 ......46

3. Public Expenditure on Health and Education in 1996-99 ............................................55

4. Developments in the Commercial Banking System, 1995-99 ...................................58

5. Composition of Bank Loans by Economic Activity, 1996-99 ......................................60

6. Prudential Indicators of Commercial Banks, 1995-99 .................................................64

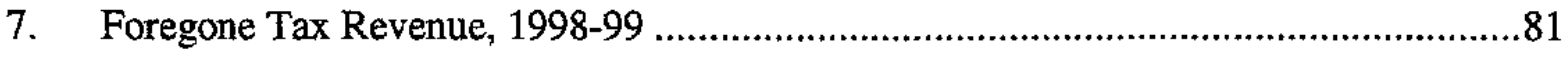

Statistical Appendix Tables

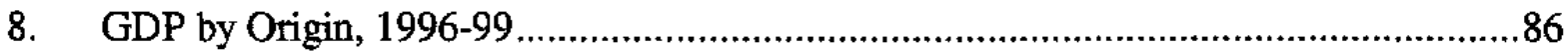

9. Production of Selected Industrial Commodities, 1995-98 ........................................8

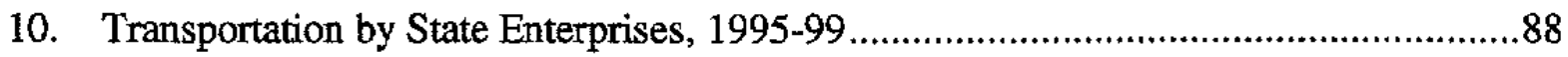

11. Population and Employment, 1995-98 …............................................................89

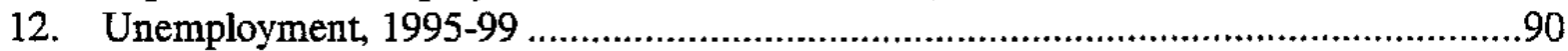

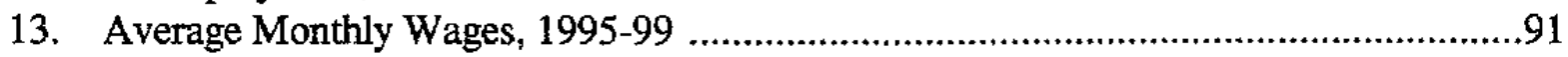

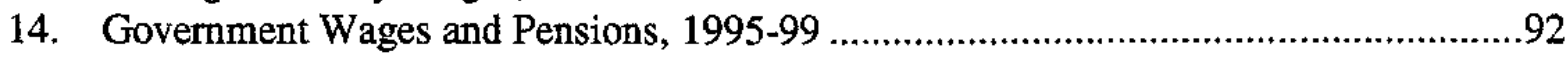

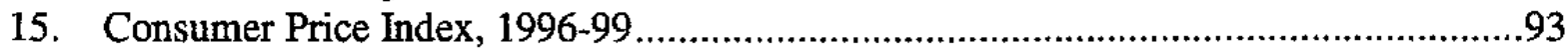

16. Summary of General Government Operations, 1995-99 _.........................................94

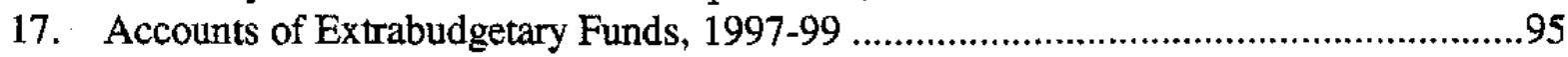

18. Marginal Rates of the Personal Income Tax, 1994-99 ...............................................96

19. Statutory Revenue Sharing Arrangements, 1998-99 …...............................................97

20. Number of Registered and Active Taxpayers, 1996-99 ..............................................98

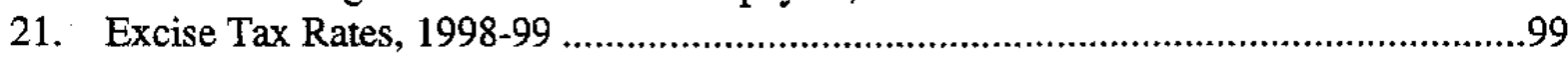

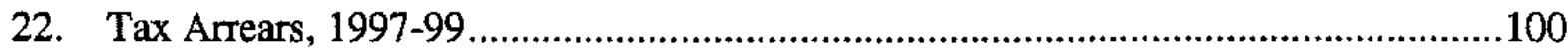

23. Public Expenditure in Education and Health, 1997-99 ..........................................101

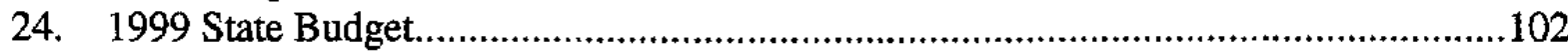

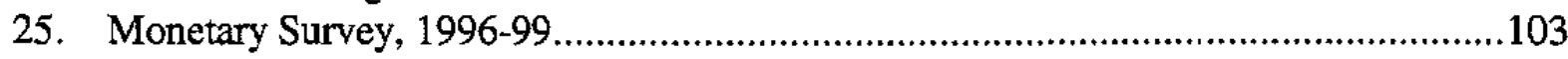

26. Accounts of the National Bank of Georgia, 1996-99 ...............................................104

27. Summary Accounts of Commerical Banks, 1996-99 ................................................105

28. Structure of Commercial Bank Deposits, 1996-99 ................................................106

29. Currency Composition of Commerical Bank Credit, 1996-99 ..................................107

30. Regulatory Framework for Commercial Banks .....................................................108

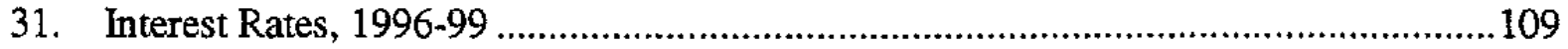

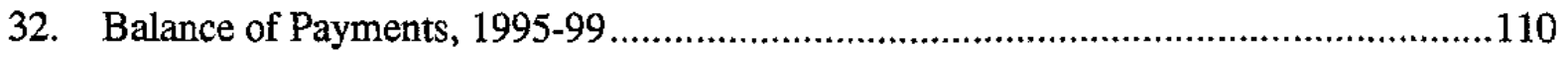


33. Geographic Distribution of Trade, by Country, 1998-99 .......................................111

34. Composition of Major Exports, 1995-98 ……..................................................112

35. Composition of Major Imports, 1995-98 .................................................................113

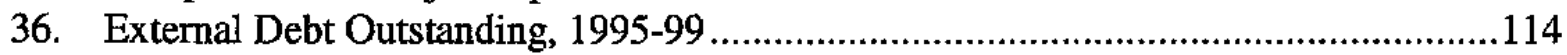

37. External Debt Service Obligations, 1995-99 …….................................................115

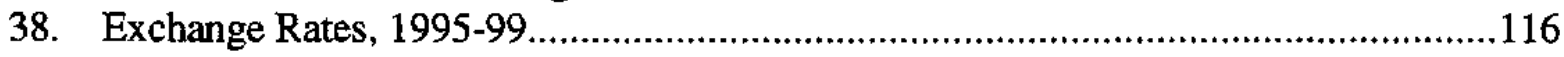

Figures

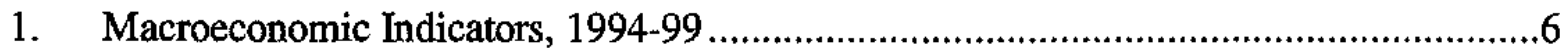

2. Real Monthly Wages for the Whole Economy, 1995-99 ........................................10

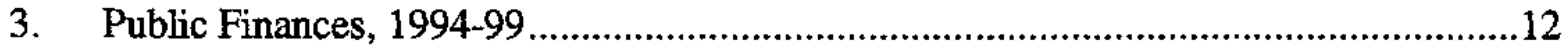

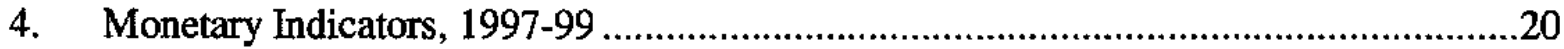

5. Foreign Exchange Market and International Reserves, 1997-99 ................................27

6. Nominal Bilateral and Real Effective Exchange Rates, 1995-99 ….............................29

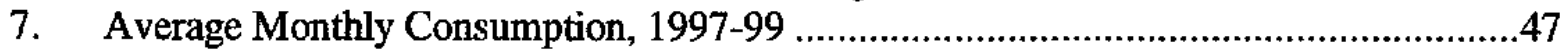

8. Assessment of Economic Conditions by Households in Tbilisi, 1997-98 ....................49

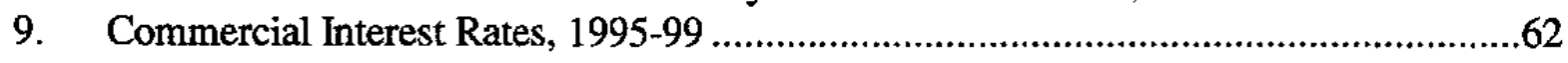


I. Social and Demographic Indicators
Area
Population density (1996)
Population (estimated 1997)
77.8 per sq. $\mathrm{km}$
Of which: percent urban
5.4 million
59.3 percent
Rate of population growth (1997)
0.13 percent
Life expectancy at birth (1997)
72.5 years
Infant mortality rate (per 1,000 tive births--1997)
17.3
Hospital beds (per 1,000 people- -1996)
4.8
GDP per capita, 1999
In lari
1,036
In U.S. dollars
512.7

\begin{tabular}{lllllll}
\hline & 1995 & 1996 & 1997 & 1998 & 1998 & Estimates \\
\hline
\end{tabular}

II. Economic Indicators

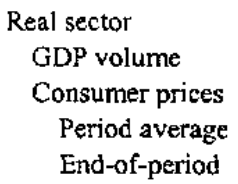

Money and credit //

Net domestic assets of the NBG

Credit to the rest of the economy $2 /$

Broad money

Including foreign currency deposits

Excluding foreign currency deposits

External Sector Exports (goods)

Imports (goods)

Trade balance

Current account (excluding transfers)

Official reserves, end-of-period

(in millions of U.S. dollars)

(in months of imports)

Memorandum items:

GDP, current prices (in millions of lari)

Exchange rate, lari/U.S. dollar

Period average

End-of-period

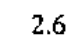

162.7

57.4

10.6

7.7

18.7

$-8.1$

$-7.0$

156.5

40.0

135.2

319.7

362.6

$-700.1$

$-337.4$

$-404.8$

156.7

2.7

2,432

1.29

1.23
(Annual percent change)

$\begin{array}{rrrr}10.5 & 10.8 & 2.9 & 3.0 \\ 39.4 & 7.1 & 3.6 & 19.1 \\ 13.7 & 7.3 & 10.6 & 10.9 \\ & & & \end{array}$

$\begin{array}{llll}14.1 & 14.8 & 16.4 & 15.6 \\ 12.2 & 14.5 & 15.4 & 14.7 \\ 21.5 & 21.8 & 22.9 & 22.3 \\ -7.4 & -7.0 & -6.5 & -6.7 \\ -7.2 & -6.3 & -5.1 & -4.9\end{array}$

(Percent change, end-of-period)

$\begin{array}{rrrr}158.5 & 53.2 & 54.7 & 15.0 \\ -14.0 & 34.9 & 37.7 & 37.4 \\ 41.9 & 45.5 & -1.2 & 20.6 \\ 38.1 & 35.4 & -11.5 & 9.6\end{array}$

(In millions of U.S. dollars)

$\begin{array}{rrrr}417.0 & 493.5 & 478.3 & 484.8 \\ -767.9 & -1052.4 & -1163.7 & -1013.0 \\ -350.9 & -558.9 & -685.4 & -528.2 \\ -415.4 & -571.3 & -599.3 & -395.0 \\ & & & \\ 158.0 & 173.3 & 118.4 & 128.5 \\ 2.5 & 2.0 & 1.2 & 1.5\end{array}$

Sources: Georgian authorities, World Bank, World Development Indicators, 1999; and Fund staff estimates.

1/ Valued at end-of-period actual exchange rates.

2/ The sharp fall in 1996, reflects the provision made for non-performing loans from commercial banks portfolio in the context of the bank restructuring program. Inclusive of this adjustment, credit to enterprises and households would have grown by about 30 percent in nominal terms during 1996. 


\section{INTRODUCTION}

1. This paper provides an overview of recent economic developments and selected issues, accompanied by a statistical appendix as background to the staff report on the 1999 Article IV consultation with Georgia. The selected issues included in the paper cover a number of important issues challenging Georgia: the rule of law, poverty, the development and regulation of banking sector, energy sector reform, and foregone tax revenue.

2. The paper is organized as follows. After providing an overview of recent developments in Section II, the report focuses on the rule of law in Georgia in Section III. Section IV examines the issue of poverty in Georgia, drawing on a poverty assessment prepared by the World Bank. Section V provides an overview of developments in the banking sector. Section VI examines the energy sector, with particular emphasis on efforts to reform the sector. Section VII provides a description of the exchange, trade and payments systems, and Section VIII presents a tax summary as of December 31,1999. A quantitative assessment of the issue of foregone tax revenue is provided in the attached Annex.

\section{RECENT ECONOMIC DEVELOPMENTS}

\section{A. Real Sector ${ }^{1}$}

\section{Output}

3. After several years of double digit growth, real GDP growth slowed to an annual rate of about 3 percent in 1998-99, following the onset of the Russia crisis combined with a severe drought in the agricultural sector (Figure 1 and Appendix I, Table 8). The lack of resilience of GDP growth to these external shocks reflected underlying structural fragilities, particularly in the fiscal and governance areas. In the second half of 1998, agricultural output fell sharply following the advent of the Russia crisis; this was exacerbated by the drought. Incipient industrial output growth came to a halt and trade activities were disrupted. Moderate GDP growth continued into 1999 with signs of a modest pick-up in the third quarter of the year, mainly on account of expansion of the service sector and moderate gains in agriculture. Meanwhile, industry showed some recovery in 1999 and construction declined substantially

\footnotetext{
${ }^{1}$ The data reflect the revised nominal GDP estimates prepared by the authorities (see Box 1).
} 
Figure 1. Georgia: Macroeconomic Indicators, 1994-99
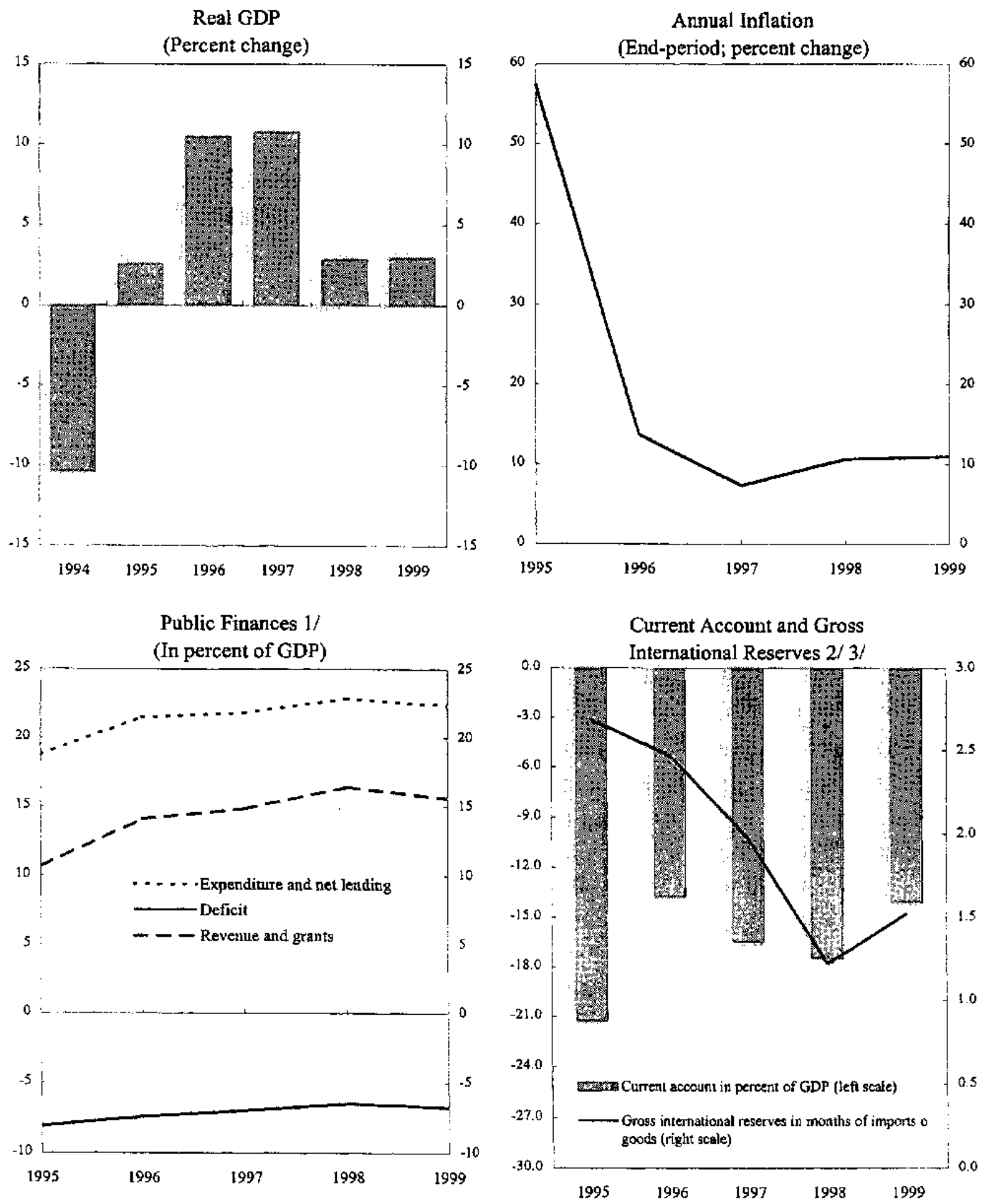

Sources: Georgian authorities; and Fund staff estimates.

1/ Commitment basis.

2/ Excluding official transfers.

3/ 1999 figures are preliminary. 
relative to the previous year, following the completion of the Baku-Supsa pipeline and Supsa terminal. The weak fiscal position also played a role in restraining growth, as the government was unable to pay private contractors as well as wages in state-owned construction companies.

\section{Box 1. Revised GDP Estimates}

Revised GDP estimates were published by the authorities in January 2000 for the period 1996-1999. These data reflect considerable work on the part of the State Department of Statistics in Georgia to address weaknesses in the compilation of national accounts statistics. A mission by the MMF's Statistics Department in December 1999 found the data to be basically sound, although a number of further refinements were recommended. The new estimates of nominal GDP are about 34 percent below the previously published data. The biggest change made to the figures was the revision to the estimates for the informal economy. In the past, informal activities were estimated at more than 40 percent of total GDP. Following the revision, these activities now account for about 25 percent, which is more consistent with those in other transition countries.

4. After a period of steady growth agricultural output, which accounts for about one-third of GDP, declined sharply in 1998 but appeared to recover somewhat in 1999. Developments in the sector during 1998, reflected inter alia the impact of extremely unfavorable weather conditions, in particular a severe drought; as well as hail and mudslides, which hit several grain-producing regions just before the harvest season. Some recovery in agriculture was registered in 1999, with a moderate output gain of about 5 percent, reflecting successful grain, tea and early potato harvests. However, the lack of a well developed land market and limited access to credit continue to constrain growth in the sector (see Section II.E).

5. Industrial output continued to decline as share of GDP in the two-year period, 1998-1999 relative to 1997, reflecting in part inadequate restructuring in a number of industries and a shortage of long-term credit. ${ }^{2}$ These developments were further aggravated by the Russia crisis in the second half of 1998. After expanding by 5 percent in 1997, industrial output fell by some 6 percent in 1998 mainly due to a sharp decline in the fourth quarter. In 1999, output recovered relative to 1998 , increasing by about $71 / 2$ percent. However, the performance among industries was uneven. Across industries, food processing companies made substantial gains in recent years, in particular in terms of fruit juice, soft drinks, beer and dairy products (Appendix I, Table 9). These products appear to have a comparative advantage over imported goods on the local market owing to lower transportation costs and cheap locallyproduced agricultural inputs. Meanwhile, although registering some gains in 1997, heavy industry suffered among the largest setbacks in 1998 relative to other industries, particularly in steel, ferrous metal and machine tools, reflecting in part inadequate restructuring.

\footnotetext{
${ }^{2}$ The dynamism of small-scale enterprises is not necessarily captured in the official statistics, as many of these firms still operate in the informal economy. The official statistics attempt to make an adjustment for informal activity.
} 
6. As in previous years, a major obstacle for private business development in Georgia was the poor state of the energy sector, mainly electricity (see Chapter VI). Despite the privatization of Telasi power company at the end of 1998, power cuts remained frequent in 1999 and the added cost of generating their own electricity (through the use of power generators) remained a major burden to enterprises. After increasing somewhat at the beginning of 1998, production and total supply of electricity declined in the fourth quarter of 1998 and in the first quarter of 1999 relative to a year ago. Output at the hydro power plants was adversely affected over this period on account of the scarcity of water following the severe drought in 1998.

\section{Labor Market Developments}

7. The labor market in Georgia is relatively free and open. Under the presidential decree of June 4,1999, the monthly minimum wage was to be binding for both private and public sector employees. ${ }^{3}$ Wage negotiations take place between employees and employers. At present, trade unions are not politically powerful. Some local and small scale strikes have taken place recently among teachers, pensioners, and workers in the energy and transport sectors due to lack of payment of wages. The major reason for the lack of powerful unions, most of which are organized under the Georgia Trade Union Amalgamation which represents $1 / 2$ million workers across 32 sectors, is that they represent workers in the formal economy, and hence exclude the sizeable number of workers in the informal economy (estimated at 750,000 as of end-1997).

8. After several years of increases, total employment in Georgia fell between end-1997 and end-1998 (Appendix I, Tabie 11). ${ }^{4}$ The decline was mainly due to a reduction in selfemployed persons, which accounted for 69 percent of total formal employment at end-1998. About 87 percent of self-employed workers are in agriculture. The large share of selfemployed workers in agriculture is explained in part by the Law on Employment, under which all people and their families with access to agricultural land (1 hectare or more) are considered to be self-employed.

\footnotetext{
${ }^{3}$ Previously, the minimum wage only pertained to employees in organizations funded under the state budget.

${ }^{4}$ These official estimates need to be treated with caution due to the inadequate coverage of informal activities, the risk of double counting as a consequence of the frequency of multiple employment, and various methodological problems with the official data.
} 
9. The unemployment rate, which was about $121 / 2$ percent at the end of 1998 , stood at 13 percent in 1999 based on the ILO standard definition (Appendix I, Table 12). ${ }^{56}$ In addition, it is likely that under-employment and hidden employment remain widespread. Many employees in the public sector are paid only token salaries on an irregular basis. In addition, a large number of laid-off workers find both primary and secondary jobs in the informal economy.

10. After registering substantial gains in 1997 and 1998, real wages in the formal sector contracted, reflecting the impact of higher inflation at the end of 1998 . Over the first half of 1999, average real wages for the total economy declined by about 6 percent, (Figure 2; Appendix I, Tables 13 and 14). Despite the gains made in earlier years, monthly wages remain very low at about US $\$ 30$ as of June 1999. Across economic sectors, the largest increase in wages was recorded in public education, where nominal wages had been unduly depressed, while wages in construction and the transport sector were among the highest in the economy. The monthly minimum wage was raised in June 1999 from lari 19 to lari 20 . Monthly minimum pensions were increased to lari 14 in November 1998. No reliable information is available about wages in the informal economy.

\section{Prices}

11. The trend decline in inflation which started in 1995 continued into 1998, with the average annual inflation rate reaching a low of 3.3 percent in November 1998 (Appendix I, Table 15). ${ }^{7}$ However, this trend was reversed after a sharp increase in inflation at end-December 1998 following the authorities' decision to stop intervening in the exchange rate market and the subsequent depreciation of the exchange rate. By April, it appeared that most of the pass-through of the exchange rate depreciation had taken place and during the summer months, seasonal factors as well as the appreciation of the lari contributed to deflation, so that the 8-month inflation through August 1999 was about 51/2 percent.

\footnotetext{
${ }^{5}$ The registered unemployment rate in 1998 was 4.2 percent, however, the unemployment figure is likely to be an understatement because many people do not find it worthwhile to register as unemployed, since the benefit is low and registration does not help in finding a job (see Chapter IV on Poverty). In addition, rural unemployment is likely to be significantly understated as it is virtually ruled out by the Law on Employment (see above) and "selfemployed" farmers account for over half of the labor force.

${ }^{6}$ The quality of information on the labor market has improved, assisted by the national Labor Force Survey, begun by the State Department of Statistics (with help from LO and UNDP) in 1998. Data from earlier periods is not fully compatible, so it is not possible to compare over time.

${ }^{7}$ Part of this was due to the abundance of cheap Russian imports on the consumer market.
} 
$-10-$

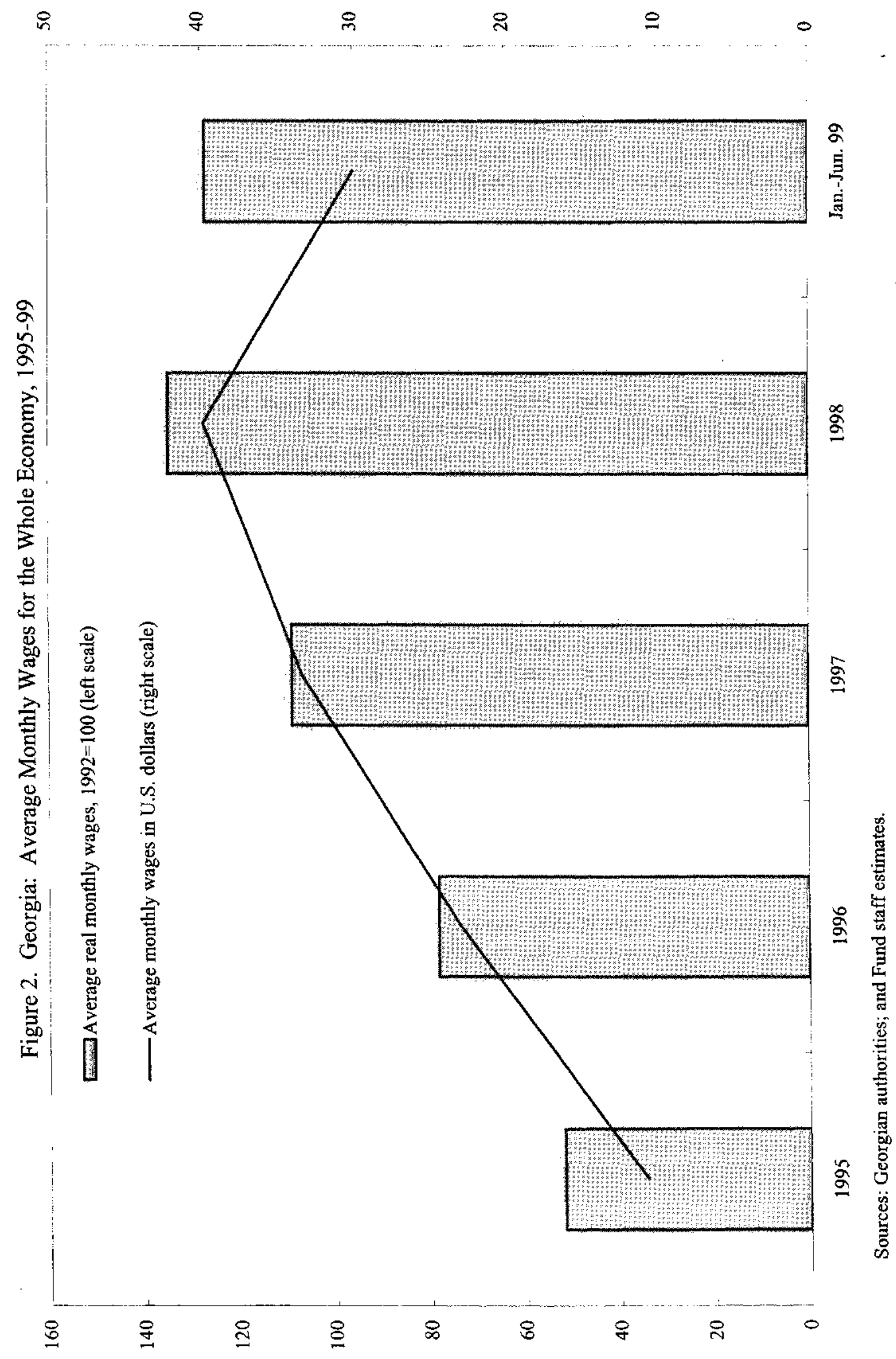


Subsequently, monthly inflation picked up as monetary policy become more accommodating. As a result, end-year inflation in 1999 was 11 percent, somewhat higher than the $10 \mathrm{l} / 2$ percent recorded in 1998.

\section{B. Fiscal Sector}

\section{Overview}

12. After several years characterized by robust improvements, fiscal performance leveledoff in 1998-99 and fell considerably short of budgetary expectations (Appendix I, Table 16 and Figure 3). While there was a reduction in the overall deficit of the general government in 1998 relative to 1997, there was also a significant shortfall in tax revenue, a large accumulation of expenditure arrears, and a decline in the ratio of tax revenue to current expenditure. Several factors contributed to these results, including the lack of a firm implementation of the fiscal measures introduced in May/June and November 1998, and the onset of the Russia crisis in mid-August which adversely affected overall economic performance. Diminishing marginal returns to improvements in tax administration and tax reforms (reflecting the fact that prior reforms had captured many of the easier gains) may also have played a role in the weakening of the overall fiscal performance in 1998. Moreover, attempts to reform the revenue collection agencies were often met with resistance by insiders who benefited from widespread corrupt practices, thus undermining revenue collections (Box 2).

\section{Box 2. Fiscal Institutional Setting}

During 1998, there were no major changes in the institutional structure of the general government, which comprises central and local governments and the extrabudgetary funds. In December 1999, a new revenue ministry was created, to which the State Tax Department (STD) and the State Customs Department (SCD) henceforth will be responsible to. The Iocal governments include two autonomous republics (Abkhasia and Adjara), 10 administrative regions, and 53 administrative districts. There are three extrabudgetary funds, the Social Security Fund (SSF), the Road Fund, and the Employment Fund, which in conjunction with the central government are referred to as the state government.

Local govemment budgets, unlike the state budget, are not subject to parliamentary approval, but are nonetheless largely influenced by the state government. For example, local governments have no legal authority to levy their own taxes, but rather are allocated a portion of revenue from the various state taxes, with the shares varying according to both the region and type of tax. In 1999, the local authorities' revenue share amounted to 30.4 percent of general government revenue. There are, however, also a group of what are essentially local taxes for which local governments receive 100 percent of the revenue, including property taxes. On the financing side, approval by the President (following advice by the Minister of Finance) is required by any jurisdiction that intends to borrow money both domestically and abroad.

13. Numerous fiscal measures were introduced by the government in May/June 1998 and again in November 1998 to redress the underlying fiscal weaknesses. The May/June measures aimed at increasing tax revenue and reducing expenditure commitments through sequestration to correct slippages in fiscal performance, especially regarding tax collections, clearance of domestic expenditure arrears, and reduction of tax arrears. The November fiscal package 
Figure 3. Georgia: Public Finances, 1995-99
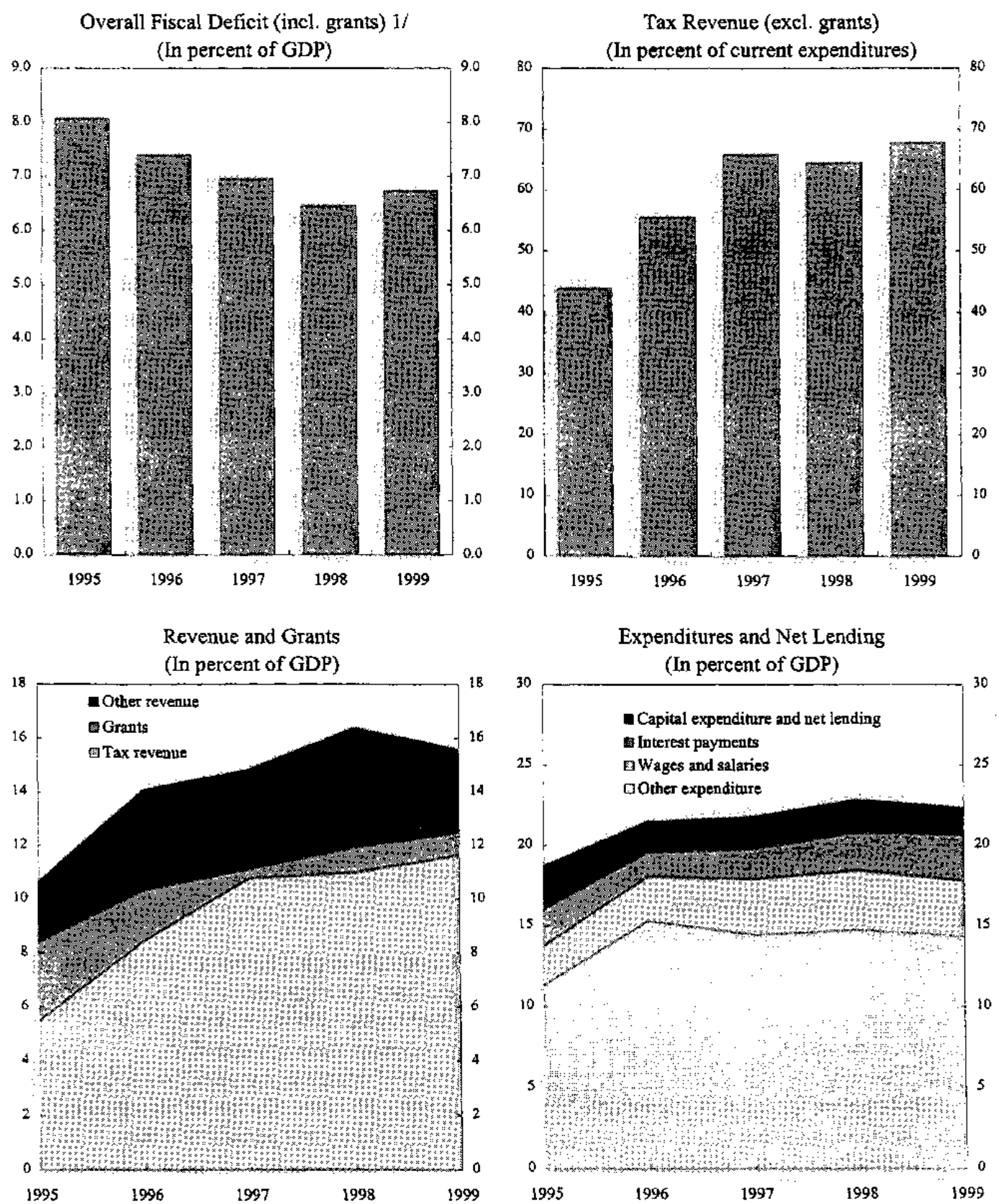

Sources: Georgian authorities; and Fund staff estimates.

1/ Commitment basis. 
reflected the authorities' renewed policy response to increasing tax revenue shortfalls experienced during the third and fourth quarters of 1998. The package included numerous measures that broadened the tax base by eliminating certain exemptions and preferential rates (Box 3). In addition, the parliament approved further expenditure cuts with respect to the 1998 budget amounting to lari 53 million (1 percent of GDP); for the most part, the cuts had already been executed de facto by the Ministry of Finance. ${ }^{8}$ Though these cuts in expenditure were insufficient to make up for the underperformance of revenues.

14. The fiscal difficulties continued through 1999. While there was progress in some areas, such as the elimination of tax offsets and the implementation of excise stamps on cigarette and alcohol, the problems of revenue shortfalls, expenditure arrears, and unrealistic budgets continued. In April 1999, excise stamps on cigarettes were introduced, and the expansion of the Large Taxpayer Inspectorate (LTD) was accelerated during the first half of the year. With effect from July 1999, the policy of granting tax offsets was abolished by decree. However, an expenditure control framework recommended by a technical assistance mission from the IMF was not implemented as expected during the year. As a consequence of this, as well as the unrealistic budget, expenditure was sequestered, but the sequestration proved insufficient to curtail spending for the remainder of the year. A revised budget for the year was therefore introduced in December 1999, partly in order to normalize, ex-post, actual expenditures that had not been approved in the original budget for the year.

\section{Fiscal deficit and Financing}

15. The fiscal stance strengthened somewhat in 1998, only to be followed by a weaker fiscal effort in 1999, reflecting the underlying weakness in revenue performance. On a commitment basis, the overall deficit of the general government declined from 7.0 percent of GDP in 1997 to 6.5 percent in 1998. On a cash basis, the decline in the overall fiscal deficit was even more pronounced (from 6.3 percent of GDP in 1997 to 5.1 percent in 1998), but this was the result of a substantial accumulation of domestic expenditure arrears, which increased to lari 140 million by end-1998 ( 2.9 percent of GDP). The primary deficit (on a commitment basis) also declined, from 5.1 percent of GDP in 1997 to 4.1 percent in 1998.

\footnotetext{
${ }^{8}$ Unlike the expenditure cuts of November 1998, the sequestration of expenditure commitments in May/June 1998 did not require parliamentary approval as the magnitude of these cuts was within the limits permitted under the budget law.
} 


\section{Box 3. Major Tax Code Changes in 1998-99}

The following amendments to the tax code were passed in November 1998 as part of the effort to boost fiscal revenue:

- Elimination of VAT exemption for movies, sporting events, and tourism;

- Elimination of VAT exemption for supply and import of wheat;

- Elimination of VAT exemption for supply and/or import of mazout, natural gas, and electricity (effective January 1, 1999);

- Elimination of VAT exemption for agriculture (effective January 1, 1999);

- Change in domestic tobacco products excises from an ad-vaiorem to a specific tax; rates per pack were set at 0.15 lari for high quality (classes I and II) and 0.05 lari for low quality. Excises taxes were also introduced on cigars ( 0.15 lari per cigar) and other tobacco products (20 lari per kilogram);

- Introduction of excise on all petroleum products (except mazout) at the rate of 60 percent; increased to 80 percent in June 2000.

- Introduction of mandatory excise stamps on all domestic and imported alcohol and tobacco products (effective April 1999);

- Increase in environmental tax on petroleum products;

- Introduction of environmental tax for the import and domestic use of plastic bottles;

- Increase in customs duty from 5 to 12 percent on mazout and wheat.

The following were other important changes following from either amendments or the expiration of transitional provisions (some of which were revenue reducing):

January 1998

- Special treatment for imports and exports to CIS countries expired.

May 1998 amendments

- Increase in VAT threshold for agricultural producers to annual turnover of lari 20,000 (lari 3,000 is standard); subsequently increased to lari 35,000 in July 1999.

- Extension of agricultural VAT exemption to April 1, 1999.

- Broadening of VAT exemptions to include tourism services, supply of wheat (would apply even after agricultural exemption expired), works of fiction, and import of natural gas, mazout, and electricity;

- Change of excises on domestic alcohol from ad-valorem to specific;

- Increases in agricultural land tax rates, most by about 30 percent;

- Reduction in the share of revenue that STD and SCD could keep (an incentive for collection) for underfulfilment of plan and increase for fulfillment of plan;

- Reduction in the VAT rate on supply and processing of bread and pasta, and wheat processing to 7 percent.

June 1998 amendment

Reduction in presumptive income tax rates for most categories, many by as much as 50 percent.

1999 amendments

- In January, the special tax treatment of imported alcohol expired and imported alcohol became subject to same VAT and excise taxation as domestic alcohol;

- In July, a reclassification of cigarette brands was introduced to reflect the filtered/unfiltered distinction, so as to facilitate WTO accession, following the earlier introduction of excise stamps in April.

- The VAT on vehicles was increased to the standard rate of 20 percent from 5 percent;

- In July, a pre-shipment inspection firm was hired to strengthen customs collections, though actual inspections did not begin until September.

16. The financing of the 1998 overall fiscal deficit (on a cash basis) relied increasingly on privatization resources, whereas domestic and external financing declined somewhat. Privatization receipts increased to 1.5 percent of GDP, compared with 0.6 percent of GDP in 1997, mainly as a result of the privatization of Telasi at end-1998. Domestic financing 
(mainly NBG credit to the central government) continued to be the largest source of deficit financing but, at 2.0 percent of GDP in 1998, it was around one and a half percentage points of GDP lower than in 1997. Net external financing also declined in 1998, from 2.2 percent of GDP in 1997 to 1.6 percent of GDP in 1998, largely reflecting increased amortization payments and the settlement of some of the stock of principal payment arrears.

17. In 1999, the fiscal stance did not improve. The overall deficit is estimated at around 6.7 percent of GDP, a deterioration of 0.2 percent of GDP relative to the 1998 outturn. Excluding grants, the overall deficit (on a commitment basis) increased by 0.2 percent of GDP to reach 7.6 percent of GDP in 1999. Because of the accumulation of expenditure arrears, the cash deficit amounted to 4.9 percent of GDP and was financed primarily with domestic credit, which totaled 2.2 percent of GDP. Domestic financing, which was almost exclusively from the National Bank of Georgia (NBG), also included a lari 70 million NBG recapitalization bond. Net external financing totaled around 1.2 percent of GDP, with disbursements, exclusively from the World Bank, roughly divided with one-third as untied (SAC and ESAC) and twothirds as project support and on-lending credit. External principal arrears to Turkmenistan were also incurred in the amount of US\$53.9 million (see Section II.D). Finally, owing to delays in large-scale privatization at 0.9 percent of GDP, this source of financing fell short of budget expectations. The primary deficit (on a commitment basis) was reduced slightly to 3.9 percent of GDP in 1999.

\section{Total revenue and grants}

18. Revenue collections improved in 1998, although the growth was slower than in previous years (Appendix I, Tables 17-22). However, collection efforts seem to have stagnated in 1999 and the growth in tax revenues, in real terms, slowed down. ${ }^{9}$ Total revenue and grants increased from 14.8 percent of GDP in 1997 to 16.4 percent in 1998 . The increase in total revenue and grants represented a continuation of the steady growth observed during the last couple of years. While in prior years the revenue gains were heavily concentrated in improvements in tax collections; in 1999, both tax and nontax revenue increased by only around half a percentage point of GDP with the remainder of the increase explained by an increase in grants of 0.7 percentage point of GDP.

19. After several years of rapid growth, overall tax revenue (including extrabudgetary funds) effectively leveled at 13.4 percent of GDP in 1998 (compared with 13.0 percent in 1997). ${ }^{10}$ The weak tax revenue growth occurred despite the numerous policy measures passed by the parliament in May and December 1998. The stock of tax arrears tripled in 1998 to reach

\footnotetext{
${ }^{9}$ It is estimated that Georgia collects only about half of potential revenue from the existing tax system (Annex I).

${ }^{10}$ The 1998 increase in tax revenue compares unfavorably with increases equivalent to 2.1 percent and 3.9 percentage points of GDP in 1997 and 1996, respectively.
} 
lari 309.6 million (6.5 percent of GDP), and an increasing portion of revenues were being collected in the form of tax offsets (Appendix Table 22). ${ }^{11}$ Tax offsets provided opportunities for corruption and incentives for taxpayers to accrue tax arrears, including as a means for clearing budgetary arrears owed to them by the government.

20. Other factors explaining the disappointing tax revenue performance in 1998 were slippages with the implementation of planned fiscal administration measures. For example, there was a delay in the introduction of excise stamps on cigarettes from October 1, 1998 to April 1, 1999, and a failure to expand the Large Taxpayer Inspectorate (LT) to include taxpayers accounting for 50 percent of tax revenue by end-October 1998 , as targeted by the government. ${ }^{12}$ Also, there were important changes in leadership and organizational structure that both symbolized and contributed to the difficulties in tax administration. In November 1998, a new Minister of Finance was appointed and in the second half of the year there were several changes in leadership at the State Tax Department (STD) and the State Customs Department (SCD). In the last quarter of 1998, there were also important organizational changes, including the removal of the STD and SCD from the control of the MOF and the transfer of payroll tax collection from the SSF to the STD.

21. Despite revenue raising measures adopted during the previous years, tax collections in 1999 continued to fall short of budget expectations. For the year as a whole, tax revenue was around 14 percent of GDP, only slightly higher than in 1998. Despite the significant depreciation of the lari, ensuing inflation, and numerous revenue raising measures, tax revenue during 1999 was only 21 percent greater in nominal terms than during the equivalent period in 1998. The performance of the customs department was particularly disappointing, with customs duty collections actually about 50 percent less in nominal terms than during 1998 and VAT collections on imports only 4 percent greater. Collection of cigarette taxes performed relatively well up until mid-year, with cigarette tax revenue accounting for 10 percent of total tax revenue and totaling 6.5 times greater than in the first half of 1998 . However, in the latter half of the year, collections fell, with cigarette tax revenue dropping to 6 percent of total revenue, partly as a consequence of widespread advance payments for excise stamps in previous months.

${ }^{11}$ Tax offsets of the state government totaled lari 104.4 million and accounted for 16 percent of total general government tax revenue in 1998. Central government offsets totaled lari 82.6 million, of which the STD accounted for 65 percent and the SCD for the remaining 35 percent. In addition, the Social Security Fund also had tax offsets totaling lari 17.5 million and the Road Fund had offsets totaling lari 4.4 million. Data on local government tax offsets are not available. The size of individual offset transactions ranged from lari 10 thousand to lari 2 million and utility companies were some of the more frequent users (the treasury maintains information on each offset transaction).

${ }^{12}$ For 1998 as a whole, the LTI collected around 32 percent of tax revenue collected by the STD (excluding SSF revenue). 
22. There was some limited progress in 1999 on the fiscal structural front. Excise stamps on cigarettes were introduced in April and contributed to the initial increase in cigarette tax revenue noted above. Excise stamps on alcohol and wine also were introduced. The practice of tax offsets was eliminated in mid-July, which while being a welcome measure could have been a contributing factor to the poor revenue performance in August and September. The VAT on automobiles was increased from 5 percent to the standard rate of 20 percent, effective July. Some administrative measures were also introduced in the summer with the intention to improve customs department revenue performance, including the hiring of a pre-shipment inspection firm and measures aimed at improving collection of petroleum product taxes.

23. Preshipment inspections actually began only in September, though, and their effectiveness appears to have been marred by problems of cooperation with customs and other departments, as well as insufficient coverage of imports that are officially subject to inspection. Likewise, uninspected imports are coming into the country through Adjara and South Ossetia, where the requirement for preshipment inspection is not being enforced. While the LTI has continued to expand its coverage of taxpayers, and toward the end of the year reached the targeted 50 percent of tax revenue, questions have been raised regarding the methods used by the LTI to select large taxpayers. More particularly, there seems to be a very large turnover of taxpayers, and many of them do not appear to qualify as large taxpayers in terms of their turnover and taxable income. This would raise suspicions that the revenue targets in the LTI are being met partly by shifting taxpayers into the fold with little regard as to whether they are actually large taxpayers or not. ${ }^{13}$

\section{Expenditure and net lending ${ }^{14}$}

24. A history of unrealistic budgets, as exemplified by the disappointing revenue collections, combined with weak expenditure controls resulted in a large-scale accumulation of expenditure arrears during 1998-99 with widespread negative social implications. During 1998 , efforts were made by the government to reduce expenditure commitments in both May/June and December. Despite these cuts, total expenditure and net lending (commitments basis) increased to 22.9 percent of GDP in 1998, 1.2 percentage points higher than in 1997 . These increases were across the board and reflected current, capital and net lending operations outlays.

\footnotetext{
${ }^{13}$ For 1999 as a whole, the LTI collected 46.5 percent at all STD revenues (excluding extra budgetary funds).

${ }^{14}$ An assessment of developments in expenditure continues to be complicated by data shortcomings that suggest movements in the composition and even level of expenditure should be interpreted with some caution. Chief among these shortcomings are problems in identifying the magnitude and composition of expenditure arrears as well as inconsistencies and errors in reported expenditure data. Overall, it should be noted that there have been important improvements in the operations of the Treasury.
} 
25. Current expenditure rose to 20.8 percent of GDP in 1998 , or 1 percentage point increase relative to 1997 . This reflected mainly an increase in interest payments and local government (non-wage) expenditures which more than compensated for a sharp reduction in spending on goods and services, which declined by 1.9 percentage points of GDP relative to 1997. Movements in other components of current spending were less marked. Wages and salaries, social allowances, and pensions were each increased by 10 percent in the latter half of 1998, with the increases in wages effected in September and pensions and social allowances in November. Current spending of the extrabudgetary funds was also higher than in 1997 (by 0.7 percentage points), reflecting higher road fund revenue (thus spending) and the increase in pensions.

26. Domestically financed capital expenditure and net lending GDP shares declined relative to 1997 , own-financed spending in these areas actually decreased. Capital expenditures, including counterpart financing, declined by 0.2 percentage points of GDP relative to 1997 , largely reflecting the expenditure cuts enacted to minimize the impact of the revenue shortfall. Furthermore, own-financed capital expenditure declined by 0.5 percentage points of GDP. Though starting from a low base, net lending increased slightly by 0.3 percentage points of GDP relative to 1997 , all financed by donors.

27. As a result of poor revenue performance and weak expenditure management, expenditure arrears rose sharply in 1998. By end-1998, the stock of domestic expenditure arrears was estimated to be around lari 140 million or 2.9 percent of GDP, having increased by 1.3 percent of GDP during the year. Wage arrears stood at around lari 40 million, split about equally between the state and local governments; this represented about 3 months' worth of wages and salaries. Pension arrears of the SSF and the state government (which pays pensions of certain law enforcement and military bodies) totaled around lari 45 million, also equivalent to approximately 3 months' worth of pensions.

28. Difficulties in parliament and uncertainties related to the path of the lari delayed the passage of the 1999 budget until March 1999 (Appendix I, Table 24). Despite its late passage, revenue shortfalls and overestimation of the central government's share of collected taxes led to a significant increase in expenditure arrears and a budget sequestration in July. The sequestration, however, was less than lari 20 million and proved to be insufficient in light of the ongoing revenue shortfalls. Subsequently, the budget for 1999 was amended by parliament in December, partly to justify ex post actual expenditure that had not been appropriated in the original budget.

29. Total expenditure and net lending in 1999 , at 22.3 percent of GDP, was slightly down from 1998, whereas current expenditure remained at 20.6 percent of GDP. However, due to higher interest payments (an increase of 0.4 percentage point of GDP relative to 1998), an increase in transfers and subsidies (of 0.3 percentage point of GDP), and an increase in local government nonwage expenditure (of 0.6 percentage point of GDP), spending on central government goods and services was compressed (a reduction of 0.8 percentage point of GDP), as was extrabudgetary expenditure (a reduction of 0.6 percentage point of GDP). Capital expenditure amounted to 0.9 percent of GDP, almost all of which was donor-financed. Arrears 
on core expenditure items increased by lari 101 million during 1999 and the stock of arrears at year-end now stands at 4.3 percent of GDP. Expenditure arrears have been incurred predominantly on wages and salaries, pensions, and social allowances, affecting the most vulnerable segments of society. Moreover, the extent of expenditure arrears is likely to be understated as the current methodology captures only a subset of arrears on core expenditure items.

30. On the structural front, progress has continued to be made in implementing the treasury system. The coverage of the treasury has been extended (including to lower levels of government and the major extrabudgetary funds), and while not all treasury accounts have yet been consolidated into a single account, progress has been made in this direction. Independent treasury accounts remain for the Ministry of Defense, Ministry of the Interior, and Ministry of State Security. Attempts are also underway to improve cash management, fiscal reporting, and control of expenditure commitments. However, while the Ministry of Finance in November issued a decree to implement the revised expenditure control and prioritization framework, this was not put in place until February 2000. Some improvements have been made to the budget preparation process; however, there is still substantial pressure on the Ministry of Finance to present budgets based on overambitious revenue targets.

\section{Monetary Sector}

\section{Overview}

31. Georgia's monetary developments were characterized by strong growth in monetary aggregates, against a background of declining inflation and exchange rate stability from 1997 through mid-August 1998. However, the situation deteriorated in the final months of 1998 (Figure 4 and Appendix I, Tables 25-31). In particular, the Russia crisis as well as widespread publicity over budgetary problems triggered a sharp decline in lari money demand, which lead to excess demand pressures in the foreign exchange market. The NBG intervened heavily in the foreign exchange market to defend the lari/dollar exchange rate, while at the same time tightening the stance of monetary policy. However, these measures were insufficient to eliminate pressures on the lari. In the event, the NBG stopped intervening in the foreign exchange market on December 7,1998, allowing the lari to float freely since then.

32. Monetary policy continued to be relatively tight in the first half of 1999, in support of the floating rate. However, by September 1999 the deteriorating budgetary situation and the run up to the elections in October placed pressure on monetary policy and there was a substantial increase in government credit, contributing to an increase in reserve money.

33. While the banking system appeared to weather the challenge posed by the effects of the Russia crisis, dollarization increased and the nascent treasury bill market was curtailed. 
Figure 4. Georgia: Monetary Indicators, 1997-99

\section{Broad Money}
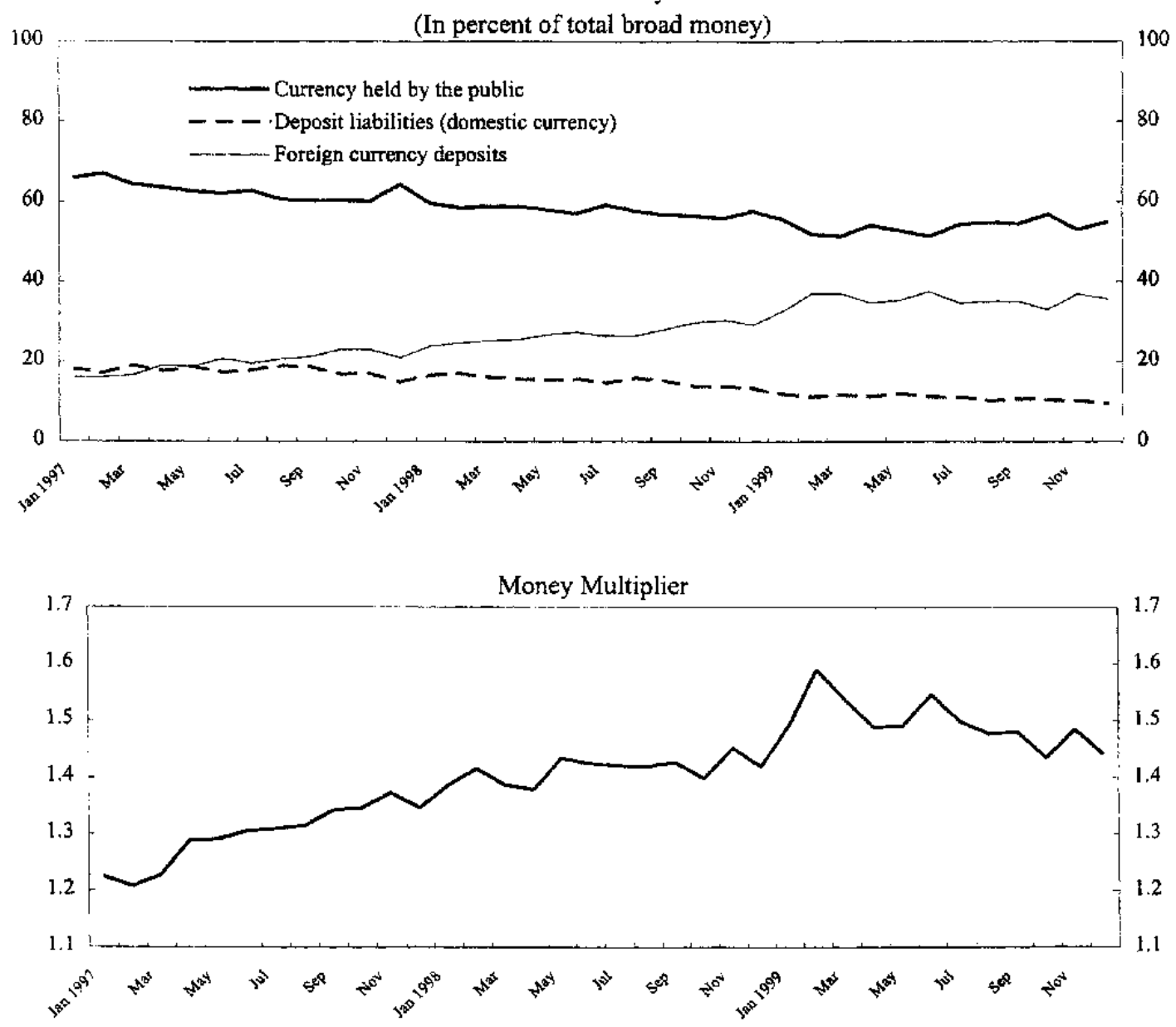

NBG Net Sales at the Interbank Credit Auctions

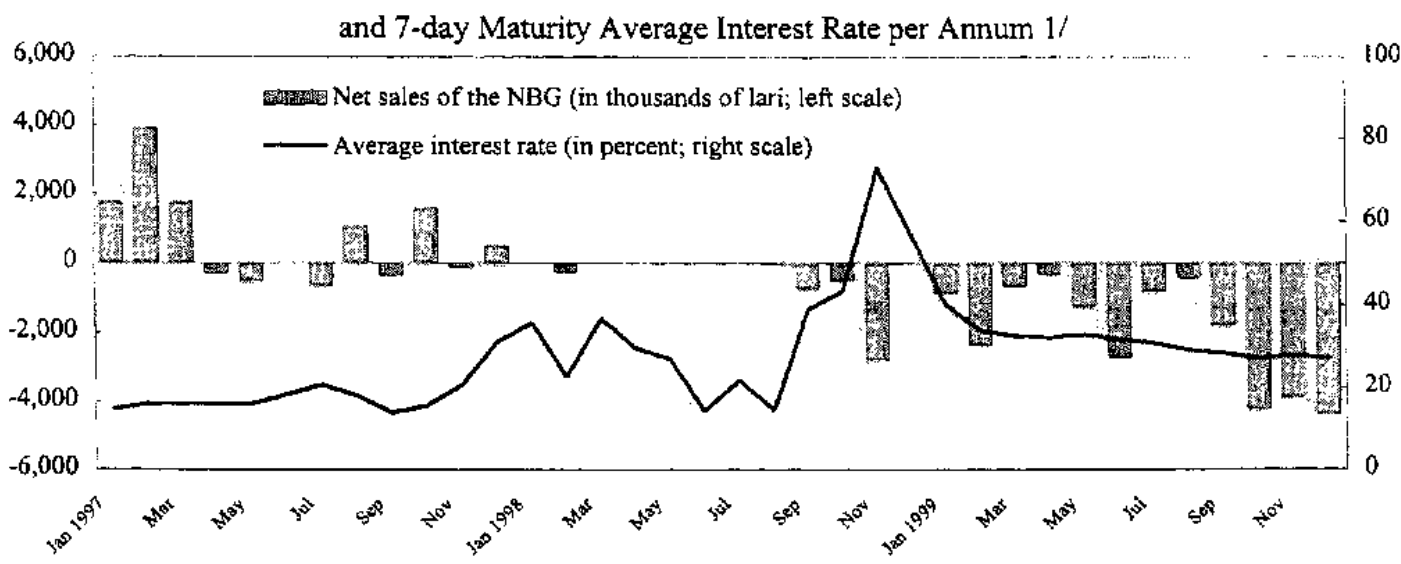

Source: National Bank of Georgia.

1/ Difference between amount sold and amount purchased. 
Moreover, the lack of a treasury bill market caused a major setback to the development of indirect monetary instruments. ${ }^{15}$

\section{Money demand, exchange rate, and interest rate developments}

34. Monetary developments, which had been characterized by financial deepening and exchange rate stability in 1997 through mid-1998, were adversely affected by the Russia crisis and the fragile fiscal position. During the first eight months of 1998, the trend increase in financial intermediation continued and the lari/dollar exchange rate remained relatively stable. At the same time, the demand for money as measured by broad money started to pick up and the exchange rate remained relatively stable, oscillating between 1.3-1.35 lari/US $\${ }^{16}$ Interest rates and treasury bills yields, which had increased sharply by end of 1997, started to decline in early 1998 and returned to levels comparable to those prevailing during most of 1997 by mid-June 1998.

35. The Russia crisis combined with the weak public finance situation during the year had an adverse effect on the financial sector, precipitating a number of important changes in market sentiment. In particular, there was a sharp decline in money demand, as well as a significant increase in dollarization of the Georgian economy and the demise of the treasury bill market, reflecting the authorities' unwillingness to let the treasury bills yield rise (to reflect increased risk) and rollover the maturing treasury bills (see Chapter V). ${ }^{17}$ Broad money (including foreign exchange deposits) fell by 25 percent between end-August and endNovember, reflecting a decline in both currency in circulation (28 percent) and commercial banks' deposit liabilities ( 21 percent).

36. In response to the external shock posed by the Russia crisis, the NBG tightened monetary policy in September 1998 and intervened heavily in the foreign exchange market. In September 1998, the NGB increased banks' reserve requirements from 12 to 16 percent,

${ }^{15}$ See Chapter $\mathrm{V}$ for a discussion of the banking sector.

${ }^{16}$ Early in 1998, the NBG had to intervene heavily in the foreign exchange market in the aftermath of a sharp expansion of central bank credit to the government in December 1997. Excess demand pressures in the foreign exchange market subsided gradually thereafter with net NBG sales of foreign exchange declining to negligible levels by June and July.

${ }^{17}$ The decline in currency in circulation reflected the increased preference for dollar assets of households and enterprises, following weakened confidence in the level of the exchange rate and expectations for a significant depreciation of the rate in the aftermath of the Russian crisis. The decline in commercial banks' deposits on the other hand, which mostly affected a limited number of mid-sized banks, was connected to cash-flow problems encountered by Georgian exporters to Russia. The dollarization of commercial banks' deposit liabilities reached nearly 70 percent as of end-1998, compared to 58 percent at end-1997 and 63 percent at end-June 1998. 
purchased credit in the interbank credit auction, and suspended the automatic intramonth financing of the budget. However, the combination of heavy intervention and a tighter monetary policy was only temporarily successful in curbing somewhat the excess demand for foreign exchange. From mid-August 1998 to December 7, there was a loss of US\$65 million in gross reserves, which drained international reserves to a low of US\$64 million (equivalent to 3 weeks of imports). The NBG stopped intervening on December 7, 1998, and allowed the lari to freely float thereafter. The nominal exchange rate vis-à-vis the U.S. dollar depreciated by about 20 percent immediately after the NBG stopped intervening (to 2.1 lari/US\$ on December 7 from 1.73 lari/US\$ the previous day).

37. Monetary policy remained tight in the first eight months of 1999 . Net credit to the government by the NBG was limited to lari 30 million (about 10 percent of reserve money) in the first 8 months of 1999, which was offset by an increase in central bank profits. As a result, the growth of monetary aggregates came entirely through expansion of net foreign assets. In 1999, the exchange rate largely fluctuated within a range of 1.9-2.2 lari/US\$ (see Section II.D). However, mounting pressures from a weakening budgetary position contributed to a sharp increase in credit to the government in the last four months of 1999, which placed pressure on the exchange rate and contributed to higher inflation in the latter part of the year. Net credit to the government by the NBG increased by lari 88 million from end-August to end-December 1999 and net foreign assets declined by lari 72 million over the same period. ${ }^{18}$

38. Remonetization began in 1999. Deposits in the banking system increased, the money multiplier rose from 1.42 in December 1998 to 1.44 as of December 1999 , and velocity fell by about 5 percent during the same period.

39. After declining in 1997 and the first part of 1998 , interest rates increased sharply in the latter half of 1998, following the deterioration in financial conditions in late August/early September (Appendix I, Table 31). The interest rate for 7-day and 30-day maturity loans in the interbank credit auction increased to 48 percent and 42 percent, respectively, in September compared to 24 percent and 26 percent, respectively, in June 1998. At the same time, no interbank credit was auctioned after November 24, as banks refused to part with liquidity in view of the uncertainty surrounding the level of the exchange rate.

40. Since the beginning of 1999 , interest rates moderated as financial conditions eased. In the second half of January 1999, the interbank credit auction resumed (once the exchange rate had stabilized) and money market interest rates dropped to around 30-35 percent. Since then, there has been a moderate decline in nominal rates to just below 30 percent as of December 1999.

${ }^{18}$ The change in net foreign assets is based on constant exchange rates and hence does not reflect valuation changes. 


\section{External Sector ${ }^{19}$}

41. Following an increase in 1997, the current account deficit (excluding transfers) widened further in 1998, from 16.5 percent of GDP in 1997 to 17.5 percent (Appendix I, Table 32). While the data on trade flows are subject to a wide margin of error, they do suggest that the impact of the Russian crisis in the last quarter of 1998 contributed to a significant slowdown of exports, as well as to a rapid growth in merchandise imports in response to the real depreciation of the Russian ruble in the last few months of 1998. In 1999, the current account deficit (excluding transfers) is estimated to have improved to about 14.1 percent of GDP.

42. According to staff estimates, merchandise exports in 1998 declined in nominal US\$ terms by 3 percent compared with the strong growth recorded over the previous two years (Appendix I, Tables 32). ${ }^{20}$ Exports showed steady improvement through the first three quarters of 1998 over the similar period in 1997 , growing by about 11 percent in nominal terms, but then fell sharply in the fourth quarter by almost 40 percent on an annual basis. Much of the decline was due to the impact of the Russian crisis in 1998; Russia was the single largest market for Georgian exports accounting for almost 29 percent of the total in 1998.

43. Total merchandise imports grew by 11 percent in 1998 compared to 37 percent in 1997 (Appendix I, Table 32). As in 1997, much of the growth in imports was driven by imports associated with the construction and refurbishment of the "early oil" pipeline connecting Azerbaijan to the Black Sea. Official imports from Russia grew sharply in the second half of 1998, in particular following the sharp devaluation of the Russian ruble in the fourth quarter of 1998. For the year as a whole, imports from Russia increased by 67 percent in nominal terms compared to 1997.

44. Staff estimates for 1999 indicate a modest pick-up in export growth and a sharp decline in imports. In line with the real depreciation of the lari from the fourth quarter of 1998 through the first quarter of 1999 , exports have increased. In particular, exports to Turkey, Germany and Italy gained momentum, while the declining trend in the share of Russia in total exports continued. The decline in import growth can, in part, be explained by the completion of the oil pipeline project.

45. According to the official trade data for 1998, Russia remained Georgia's largest trading partner, accounting for 29 percent of its export market, and 15 percent of its total

${ }^{19}$ The balance of payments data in Georgia are extremely weak. There have been numerous revisions over the past year. Preliminary data is available for 1998 and 1999, but is likely to be revised again.

${ }^{20}$ The IMF's Direction of Trade Statistics (DOT), however, indicate that exports grew in value by about 40 percent in 1998 , while preliminary official data indicate a decline of about 20 percent. Such large discrepancies are reflective of the inadequate quality of BOP statistics. 
imports. Following Russia were Turkey (11 percent of exports, 11 percent of imports) and Azerbaijan (10 percent of exports and 8 percent imports). ${ }^{21}$ In 1999 , Russia's share of Georgian exports declined to 19 percent, while the share of Turkey (16 percent), Germany (10.3 percent) increased significantly. Russia's share in Georgian imports increased further to 19 percent in 1999. The share of imports of the United States, Turkey, and France also increased.

46. The service account continued to improve, registering a surplus of US\$86 million in 1998 , compared to a deficit of US\$12 million in 1997. Much of this improvement was due to the strong growth in credit for business and personal travel and, in particular, in the compensation of short-term Georgian workers living abroad. ${ }^{22}$ Inflows from short-term workers' compensation were estimated to be around US\$186 million in 1998 compared to US\$181 million in 1997. Despite the fallout from the Russia crisis, inflows of short-term workers' compensation remained strong throughout 1998, and actually grew during the last quarter of the year. While most short-term workers are employed in the Baltics, Russia, and other former Soviet Union countries (BRO), some of them are also located in Australia, Germany, Greece, Turkey, and the United States and their incomes were likely not affected significantly by the Russian crisis. ${ }^{23}$ Income from business and personal travel also recorded a net increase, largely due to the increased number of foreigners visiting Georgia for tourism and business-related reasons. The improvements in the credit side of the service account are estimated to have continued in 1999.

47. On the debit side of the service account, interest payments on external debt in 1998 amounted to US\$42 million of which US\$32 million was for Georgia's quarterly payment to the special account of the Netherlands Bank for interest on rescheduled debt. The remaining US $\$ 10$ million represented interest payments to multilaterals and for new bilateral lending. Georgia remained current on all interest obligations falling due in 1999. Interest payments in 1999 amounted to US\$50 million, of which US\$32 million was interest due to bilateral creditors on rescheduled debt.

48. Transfers (including private transfers) totaled US $\$ 211$ million in 1998, up from US\$196 million in 1997. Official transfers, of which the EU, the Netherlands, and the United

\footnotetext{
${ }^{21}$ Data from the IMF's Direction of Trade Statistics, however, indicate that Turkey, and not Russia, is Georgia's largest trading partner.

${ }^{22}$ In the balance of payments, these workers are classified as residents since they reside abroad for less than one year.

${ }^{23}$ Household surveys conducted by the State Department of Statistics indicate that one in every four families in Georgia have at least one member who is employed abroad on a short-term basis. Many of these short-term workers are reportedly engaged in construction and manufacturing.
} 
States are the largest contributors, fell in 1998. By contrast, private transfers, made up of remittances from long-term Georgians working abroad, grew from US\$103 million in 1997 to US\$137 million in 1998. As with the compensation to short-term workers, the inflow of workers' remittances remained steady during 1998, despite the impact of the Russian crisis. In 1999 , transfers are estimated to be about US $\$ 175$ million, of which official transfers amount to about US\$68 million.

49. The capital account remained almost unchanged compared to 1997, largely on account of a small decline in foreign direct investment and the drawdown of foreign exchange reserves of the commercial banks. Total disbursements of medium and long-term loans grew by 5 percent to US\$112 million. The World Bank remained one of Georgia's largest creditors with total lending of around US\$74 million in 1998. The World Bank approved several IDA projects in 1998 including those for Enterprise Development, Cultural Heritage, and Coastal Integration. In addition, the World Bank disbursed the second tranche under its SAC II program of US\$20 million in December 1998. The EBRD approved two projects in 1998-the Enguri Hydropower Plant and the Trans Caucasian Rail Link, and disbursed US\$9 million under existing projects in the areas of banking, manufacturing, and power rehabilitation. The remaining disbursements were made up of new bilateral lending from Germany and the U.S. which amounted to around US\$30 million. Disbursements of medium- and long-term loans in 1999 amounted to about US\$145 million. Disbursements from the World Bank in 1999 totaled US\$74 million. In addition to disbursements of US\$20 million from SAC III and US\$12.5 million from the ESAC, disbursements in support of projects in the areas of education, water facilities, enterprise development, judicial reform, and coastal integration account for the rest. Disbursements from the EBRD in 1999 amount to US\$33 million. These were directed at ongoing projects in power rehabilitation and the Trans Caucasian Rail link. The remaining disbursements were make up of new bilateral lending from Germany, Japan, and commercial loans.

50. Amortization payments falling due in 1998 totaled US\$79 million, all of which were due to Turkmenistan. In December 1998, Georgia made a payment of US\$22 million to Turkmenistan, of which US\$19.8 million equaled one quarterly amortization payment on debt obligations, while US $\$ 2.2$ million was payment toward extinguishing arrears on payments for gas imports in 1995. Georgia's external arrears to Turkmenistan amounted to US\$59 million in 1998. With Georgia making a payment of US\$25 million to Turkmenistan in December 1999 as partial payment toward principal obligations of US\$79 million falling due in 1999 , arrears to Turkmenistan increased to USS\$113 million at end-1999.

51. Other capital, which includes foreign direct investment (FDI) and foreign exchange deposits in commercial banks increased to US\$218 million in 1998. FDI fell slightly from US\$236 million in 1997 to US\$221 million in 1998-as a share of GDP, from 4.5 percent to 4.2 percent. Much of the FDI was due to the work of the "early oil" pipeline linking Sanachal in Azerbaijan and Supsa in Georgia which was completed in early 1999. Investment in the oil pipeline was estimated to be around US\$174 million in 1998. Other major areas for FDI include energy and light industry (e.g., food, glass, and pharmaceuticals). The largest source of 
FDI flows was the U.S., followed by the U.K., Azerbaijan, and Russia. FDI in 1999 is estimated to have declined sharply, reflecting the completion of the oil-pipeline project.

52. Exceptional financing in 1998, which included macroeconomic support from the EU, other exceptional assistance, and external arrears financing, amounted to US\$36 million in 1998. In July 1998, Georgia cleared its outstanding arrears with the EU, totaling around Euro 131 million (US\$144 million), as part of an exceptional financial assistance package agreed in December 1997. In return, the EU disbursed a new loan of Euro 110 million (US\$123 million), and has also agreed as part of its exceptional assistance package, to provide up to Euro 55 million (US\$65 million) in grant assistance to be disbursed in successive annual tranches for helping meet Georgia's future obligations to the EU. The first grant tranche of Euro 10 million was received in August 1998, while a second tranche for Euro 9 million was received in September 1999. In July 1998, Georgia received the first disbursement of US $\$ 37$ million under the third-year ESAF arrangement. Exceptional financing in 1999 included external arrears financing of US\$54 million (Turkmenistan) and Fund financing. In July 1999, the Executive Board completed a review of Georgia's ESAF arrangement and, as a result, Georgia made the final purchase under the ESAF-supported program of US\$46 million in August.

53. Gross international reserves fell by some US\$55 million, from US\$173 million at end-1997 to US\$118 million at end-1998 (Figure 5). ${ }^{24}$ In terms of import coverage, gross reserves fell from 2 months in 1997 to 1.2 months in 1998. For the year, foreign exchange inflows to the NBG amounted to US\$116 million, of which about half (US\$57 million) represented disbursements from the IMF and the World Bank. Foreign exchange outflows for 1998 totaled US\$171 million, of which US\$42 million was for official debt-service payments. The gross international reserves position remained almost flat as of end-1999 relative to end1998. Reserves at end-1999 were US $\$ 128.5$ million, providing a cover of about 1.5 months of imports of goods and services. Foreign inflows totaled US\$105 million, of which disbursements from the World Bank and the Fund accounted for about US\$80 million. Grants from the EU for debt operation account for about US\$9 million. Outflows totaled US\$99 million, most of which represented debt servicing.

54. At the end of 1999 , Georgia's total stock of external debt stood at US\$1,754 million, of which nearly all is public or publicly-guaranteed debt (Appendix I, Table 36). ${ }^{25}$ External debt rose from 44 percent of GDP in 1997 to 63 percent in 1999. Multilateral creditors, including the IMF, made up around 52 percent of the entire stock, while bilateral debt made up

\footnotetext{
${ }^{24}$ Of the total US $\$ 118$ million in gross reserves, all but US $\$ 1.5$ million were as freely usable reserves.

${ }^{25}$ A full accounting of debts contracted or guaranteed by the government in the energy sector has not yet been completed (see Chapter VD).
} 
Figure 5. Georgia: Foreign Exchange Market and International Reserves, 1997-99
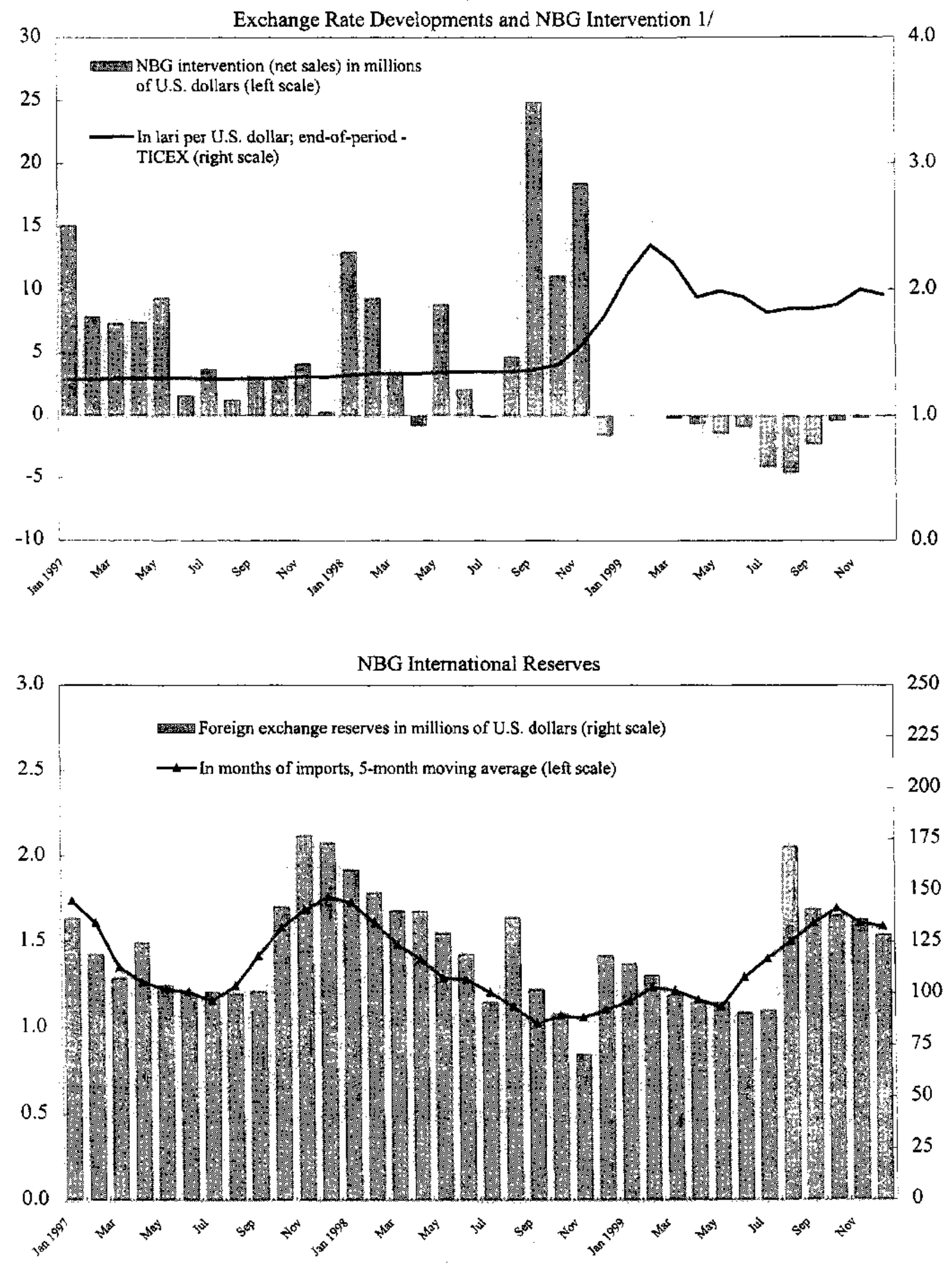

Source: National Bank of Georgia.

1/ No interventions occurred in January nor February 1999. 
the rest. Of the total stock of bilateral debt, Turkmenistan is the largest creditor ( 20 percent of the total stock of external debt), followed by Russia ( 10 percent) and Austria ( 6 percent).

55. Actual debt-service payments in 1998 amounted to US\$89 million, of which US\$22 million was for principal repayment. Georgia continued making quarterly interest payments of US\$8 million into a special account at the Netherlands Bank on its rescheduled stock of bilateral debt while it remained current on all other interest payments. Total debt service due as a share of exports of goods and non-factor services increased from 6 percent in 1997 to 17 percent in 1998. In February 1998, Turkey agreed to reschedule its stock of debt valued at US\$54 million with an interest rate of 4 percent, 7 years grace from end-1994, and 16 years maturity. As a result of the agreement with Turkey, Georgia has now concluded a round of debt rescheduling with all its bilateral creditors. Debt-service payments in 1999 amounted to US\$77 million, of which US\$25 million was partial payment toward obligations falling due to Turkmenistan. Georgia continued to remain current on all interest payments.

56. The nominal exchange rate against the U.S. dollar depreciated sharply in 1998 by 27 percent, following a 3 percent decline in 1997. Much of the decline took place in the last three months of the year (Appendix I, Table 38). The end-of-period lari/US\$ exchange rate declined from 1.304 in end-1997 to 1.790 at end-1998. At end-March 1999, the exchange rate has depreciated even further to 2.215 . Since then, however, it has appreciated and remained stable at about 2 lari/US\$.

57. Largely as a result of its continued low inflation relative to its partner countries, the real effective exchange rate for Georgia is estimated to have declined in 1998 by about 8 percent. End-of-period inflation in Georgia was estimated to be 11 percent in 1998 , compared to 29 percent in its partner countries. In 1998, in real terms, the Georgian lari depreciated against the Turkish lira by 25 percent, the U.S. dollar by 19 percent, the Azeri manat by 17 percent, and the Armenian dram by 14 percent (Figure 6). However, against the Russian rouble, the lari appreciated in real terms by 49 percent in 1998 . After a real depreciation between November 1998 through the first quarter of 1999 ( 9 percent), there has been a gradual appreciation of the lari through September (18 percent). This trend in the real effective rate is discernible across the currencies of all major trading partners.

\section{Trade policy}

58. Georgia's trade regime is considered to be one of the most liberal and open trade systems among the BRO countries. Georgia maintains a two-tier tariff regime (5 and 12 percent); the import-weighted average tariff rate is estimated to be 3.9 percent. ${ }^{26}$ Effective July 1,1998 , the export ban on scrap metal was abolished and replaced with a specific custom duty, and the license fee on the exports of logs was eliminated. In 1999, the export tax on

${ }^{26}$ Official estimates. 
Figure 6. Georgia: Bilateral and Real Effective Exchange Rates, 1995-99 1/ $(1995=100)$

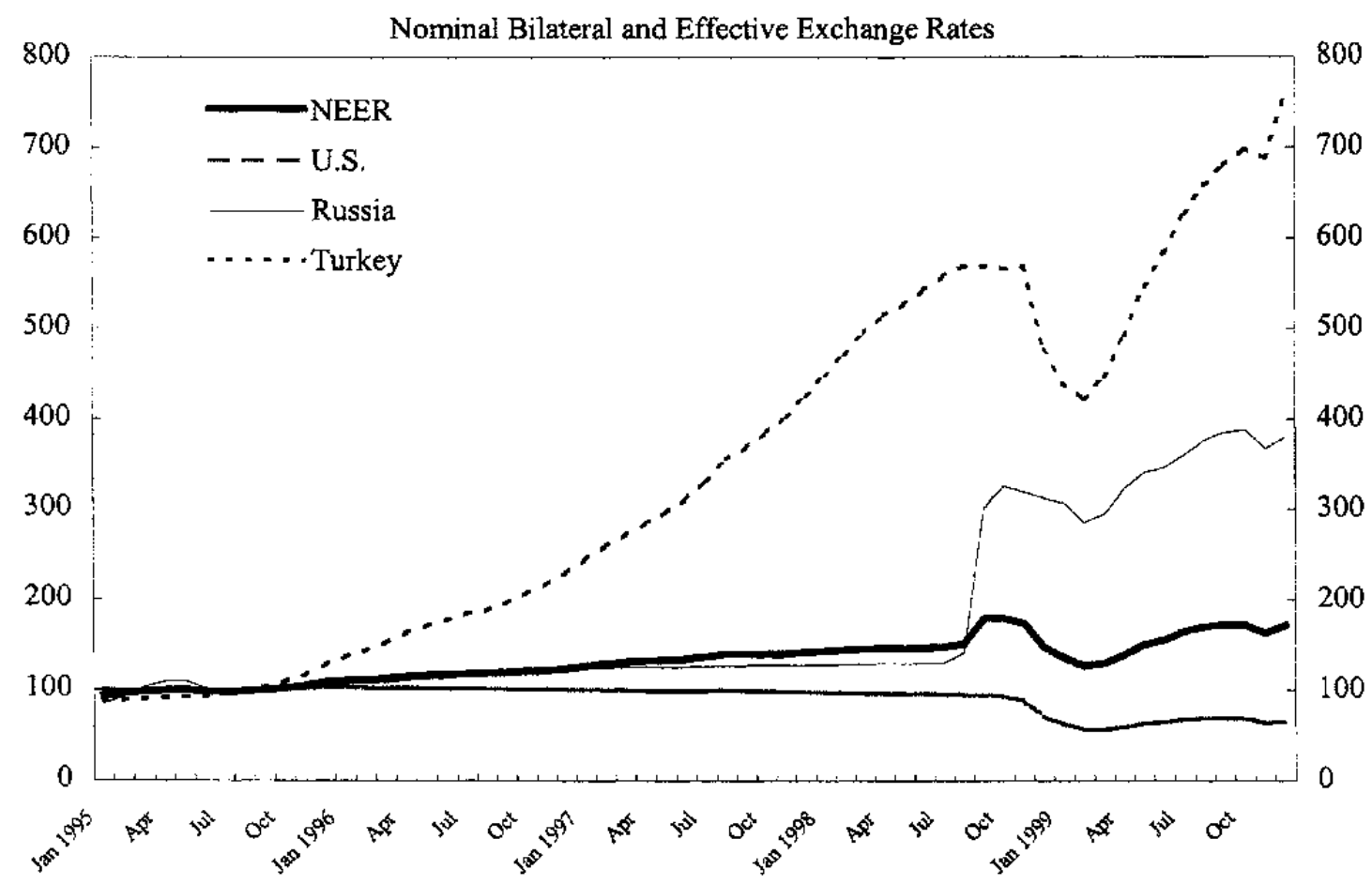

Real Bilateral and Effective Exchange Rates

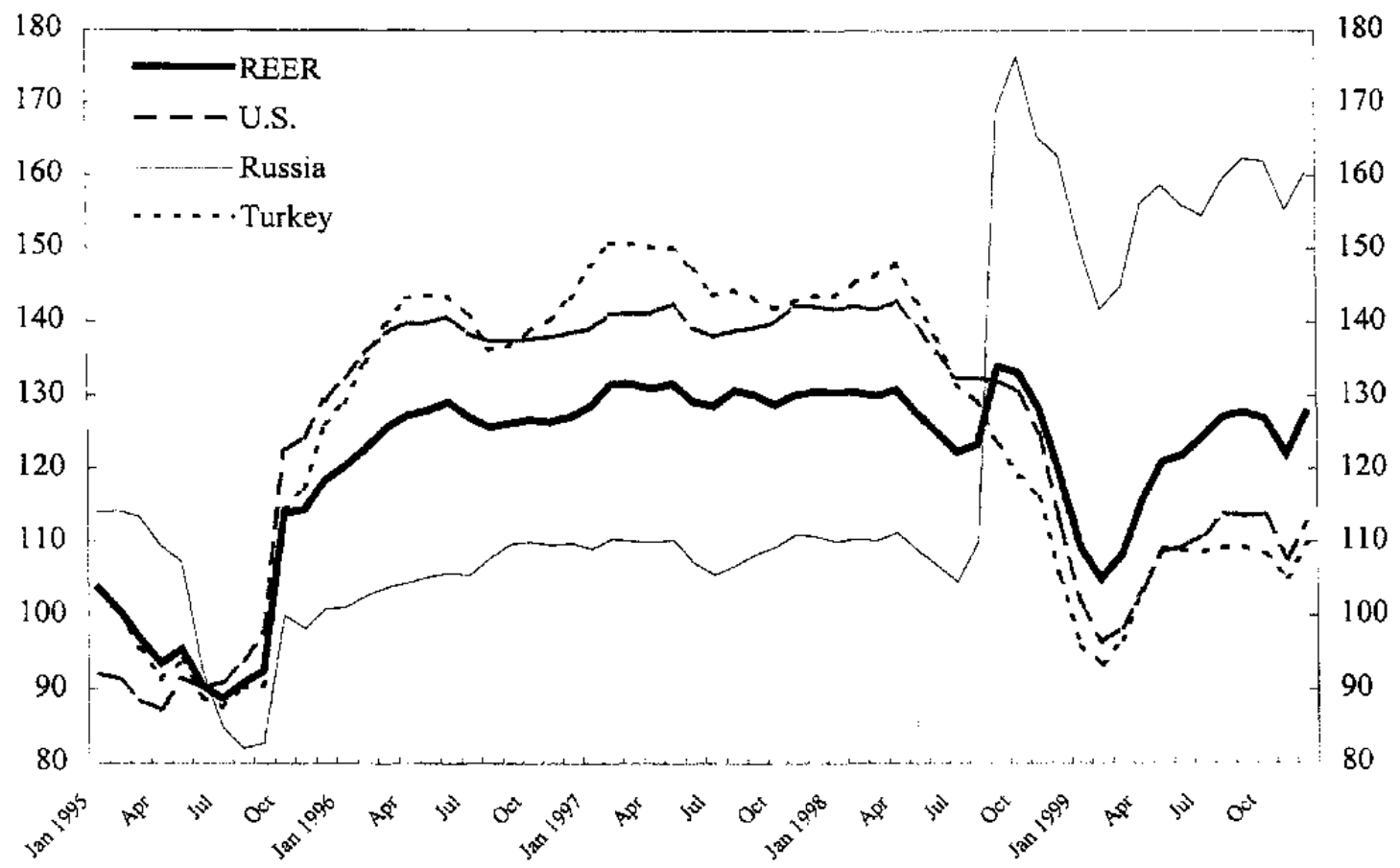

Source: IMF, Information Notice System; and Fund staff estimates.

$1 /$ Increase indicates appreciation. 
scrap metal was eliminated. A new customs law, developed in cooperation with the World Bank, became effective in late March $1998 .^{27}$

59. The World Trade Organization (WTO) General Council ratified the Final Working Party document for Georgia on October 6, 1999, thus clearing the way for Georgia's accession to the WTO. Georgia's parliament now needs to ratify the WTO Protocol of Accession.

\section{E. Structural Reform ${ }^{28}$}

60. While there has been significant progress in small scale privatization, the government's program for medium- and large-scale privatization has only just started to be implemented. ${ }^{29}$ Some 12,860 small scale enterprises were privatized between 1993-98 and about 80 percent were in the trade and services sector. While 900 of the 1,250 medium and large-scale enterprises had been privatized by end-1998, the majority of enterprise equity remained in government hands (estimated at over 75 percent of the original state-owned portion), as most of the enterprises sold were small, with relatively low asset values.

61. To accelerate the privatization of medium-and large-scale enterprises, a new law, which allowed for auctions without floor prices, was introduced in May 1999. A new privatization strategy, which will gradually include nearly all infrastructure (e.g., telecommunications, postal services, railways, ports), was adopted in 1998; this was supported by a Presidential decree abolishing a previous regulation suspending the privatization of "strategic" enterprises. The highlight of the reform program was the privatization of the Telasi power company in December 1998, with 75 percent of the shares sold to a U.S. investor (AES) via international tender (See Chapter VI). Receipts from the sale of Telasi (approximately US\$25 million) represented an important source of foreign financing for the central and local governments. ${ }^{30}$

${ }^{27}$ See Box 3 in SM/98/142.

${ }^{28}$ Eka Vashakmadze, an economist in the Resident Representative Office, contributed to this section.

${ }^{29}$ The definition of small-scale versus medium-large scale enterprises is based on several factors: number of employees, book value, and the importance of the enterprise in the particular economic sector and in the overall economy. According to the book value definition, small-scale enterprises have a book value less than US $\$ 44,000$ and large-scale enterprises have a book value of more than US\$500,000. However, due to other factors noted previously, the classification may deviate from the book value definition.

${ }^{30}$ Budgetary receipts from Telasi, which accounted for more than 60 percent of all privatization proceeds, totaled about US\$23 million, with 75 percent accruing to the central budget, 23 percent to the Tbilisi government, and 2 percent paid as a brokerage commission to the investment bank. 
62. During 1999, about 50 medium- and large-scale enterprises were privatized through tender, public auction, direct sale or liquidation. These privatized enterprises included major producers in cement, tobacco, textiles, construction and mining. However, total receipts amounted to only lari 52 million, reflecting enterprise indebtedness, the poor state of the capital stock, and social obligations. In 1998-99, the government entered into four-year management contracts with four companies-Rustavi metallurgical plant, Madneuli cooper/gold mine, Phero (non-ferrous metallurgical) plant, and Borjomi bottled mineral water plant-which are scheduled to run until 2002-3. The government is committed to the full privatization of these enterprises once the management contracts expire.

63. Agricultural land privatization, which began in 1992, continued in 1996-97 through land leasing programs and then accelerated in 1999 through the survey and registration of agricultural land. ${ }^{31}$ The government's reform program envisages the creation of a land registration system, which would be the basis for the development of a land market (e.g., bank collateral, mortgage of land). In 1999, with assistance from the World Bank and USAID, the government was able to start the registration of agricultural land parcels that had been surveyed. As of December 1999, approximately 330,000 plots had been titled.

64. Privatization of urban and industrial land started in 1998. By end-1999, over 3,200 private enterprises had registered their land holdings with the regional and municipal registrars of the State Department of Land Management. The law allows the sale of land to privatized enterprises, private legal persons, and private citizens based on existing documentation without additional surveying. ${ }^{32}$ The registration of the privatized land is also envisaged.

65. A second law created the framework for the privatization and lease of state-owned nonagricultural land. ${ }^{33}$ The shortcomings in the initial version of the law, e.g., leasing in favor of privatization, and broad discretionary powers for the government agencies in charge of the land's disposal were eliminated. However, the regulations for full enforcement of the law are not yet worked out.

66. Another important step toward structural reform was the government's initiatives in the area of judicial reform. Judges were required to pass an examination in order to retain their seats. In May 1999, 150 new judges were sworn in following four examinations; these examinations were judged to have been fair by international observers (see Chapter III).

${ }^{31}$ Around 50 percent of the agricultural land has been privatized and farmers have already received preliminary ownership rights to the land. The nonprivatized agricultural land is mainly plots with minimum potential for agricultural production and/or plots designated for scientific research.

${ }^{32}$ Law on the "Declaration of Private Ownership on Nonagricultural Land in Use of Physical and Legal Private Persons."

${ }^{33}$ Law on the "Administration and Disposition of State-owned Nonagricultural Land." 


\section{THE RULE OF LAW}

67. Georgia has made significant, but incomplete, progress toward establishing the rule of law, that is, the application of the due process of law, without regards to the circumstances or individuals involved. Since 1995, Georgia has made progress in creating political stability and establishing the legal and regulatory framework for a market economy. Nonetheless, informal networks persist (regional, personal and clan based) which may lead to the flexible interpretation of commitments-whether embodied in laws, contracts, or other commitments. The absence of a well established rule of law poses a constraint on financial stabilization and the development of a formal market economy. Until the rule of law is more firmly established robust formal sector growth will likely remain elusive and tax collections at an extremely low level relative to the size of the economy.

\section{Establishing the Rule of Law}

68. The principal concept in the rule of law is the supremacy of the legislative framework over other considerations-in other words a law-based state as specified in Article 1 of the Constitution of Georgia. In principle, state power is to be exercised and based upon legal principles as specified in Article 54 of the Constitution of Georgia and state officials and their agents act in accordance with the law. Moreover, the law is meant to be accessible to all individuals and legal claims are to be recognized and enforced. Where disputes arise, they are meant to be resolved through impartial adjudication through the appropriate legal body. Correspondingly, this implies that the judiciary is in principle broadly independent of the executive.

69. An important part of Georgia's legacy from the Soviet period has been an inheritance of strong informal networks defined by regional, personal or clan loyalties. These informal networks thrived in the command economy environment as a means of allocating resources outside of the externally determined economic plan. As a result, a culture which accepted rulebreaking arose in conjunction with a subtle system of persuading outsiders that the plan or other rules were being followed faithfully. Civil unrest in the early 1990's combined with a reduction of the effectiveness of state bodies further reinforced informal networks and the shadow economy. Nonetheless, in the transition from a planned economy to a market economy, the legacy of informal networks has been increasingly challenged by the emerging rule of law which allocates resources and resolves disputes according to clearly specified legislative norms.

\section{Preconditions for Rule of Law}

70. Georgia successfully established a constitutional parliamentary democracy, after a period of civil war and economic instability that ensued after regaining independence. In August 1995, a new constitution of Georgia was enacted which set the basic framework of a law-based state. Shortly thereafter, national elections in accordance with the constitution put in place the head of state and parliament against a background of increasing political stability. Local elections in November 1998 passed control of city councils in six major cities to the 
opposition. National parliamentary elections in October 1999 also confirmed the continuity of a democratically elected legislature.

71. The democratic process has withstood several potential threats, including two assassination attempts against President Shevardnadze (September 1995 and January 1998). Political stability has also been achieved in the face of significant internal and regional territorial tensions. The Abkhazia region-and to a lesser extent the region of South Ossetia-continues to contest Georgian sovereignty while the autonomous region of Ajara periodically challenges central authority. Moreover, the regional situation remains tense with Russian military activity in both Chechnya and Dagestan regions of the Russian Federation in 1999.

\section{Development of the Legislative Framework}

72. Georgia has continued to develop the legal framework for a market economy. Since 1995, laws enacted by parliament have increasingly displaced Presidential decrees as the main vehicle for decision making (see below) ${ }^{34}$ In 1997 , legislative codes were approved for the tax system, customs system, and a civil code; although these have been periodically amended. During 1998-99, the parliament passed the criminal code, criminal procedure code and the administrative code.

\begin{tabular}{|cccccccccc|}
\hline \multicolumn{10}{|c|}{ Georgia: Number of New Laws and Codes Approved by Parliament } \\
\hline 1990 & 1991 & 1992 & 1993 & 1994 & 1995 & 1996 & 1997 1/ & 1998 2/ & $19993 /$ \\
\hline 4 & 2 & 0 & 7 & 7 & 12 & 57 & 61 & 58 & 51 \\
\hline
\end{tabular}

1/ Includes five codes: Naval, Tax, Civil, Customs and Civil Procedural.

$2 /$ Includes Administrative Code and Criminal Procedure Code.

3/ January-September. Includes Forest Code and Criminal Code.

73. Significant progress has been made in adopting legislation that regulates a market economy. As discussed in Box 4, legislation has been enacted for the operation of the land market and securities market, for adopting international accounting standards, and reforming the judicial system.

\footnotetext{
${ }^{34}$ The number of Presidential decrees issued from 1996 to 1999 were 747, 720, 696, and 800, respectively. While the decrees remain numerous, they are mainly used to instruct the executive to take specified administrative actions rather than legislative actions.
} 


\section{Enforcement of Legislation}

74. The judiciary does not yet enjoy the broad support of the population in impartially applying the legislative base, according to consumer surveys, although the authorities have prioritized improvement of the judicial system to address these concerns.

75. As discussed in Box 4, parliament passed the Law on Common Courts, which requires judges to pass an examination in order to retain their seats. The Constitutional Court suspended part of this law in 1998, relating to the appointment of judges, on the grounds that it provided insufficient basis to remove judges before their term was complete. However, an amendment to the Law on Common Courts addressed the legal basis of this ruling, and newly accredited judges began to take their seats in mid-1999, following four examinations judged to be fair by international observers. The law also provides for increased salaries for judges. While the new judges are being selected in a transparent manner, they will remain a focus of financial and political pressure. An additional unresolved issue is whether "lay judges" selected through a political process will continue to adjudicate in serious criminal cases.

76. Further reforms to the legal process are in progress. During 1999, public notaries have begun an accreditation process. In 2001, an accreditation procedure for officials in the procuracy is envisaged.

77. Enforcement of legislation is also hampered by ambiguity in many of the legal texts. In part, this reflects outdated legislation still in effect, the rapid pace of the legislative drafting process and lack of familiarity with new laws. Legal problems take a number of forms including: imprecise definition of terms in laws; imprecise drafting of laws which makes two or more interpretations possible; contradictory drafting in different laws; technical errors, e.g., in cross-referencing other articles; and subsidiary implementing regulations not consistent with governing law.

78. Government officials also have a reputation for dishonesty in the eyes of the public, businessmen, and other government officials, as established by a World Bank sponsored survey in 1998. Officials are not seen as objective enforcers of regulations. On the contrary, it is not unusual for government officials and departments to operate businesses, some in areas which they regulate. 


\section{Box 4. Legislative Steps Toward a Market Economy}

This box summarizes key recent legislative initiatives which have contributed to building the foundations of a market economy in Georgia:

- The "Law on General Courts", adopted in June 1997, provided a basis for a comprehensive judicial reform of the court system. The law has undergone a number of amendments. The law affirmed the independence of judges and the judiciary from the executive and legislative branches of government. The law required a reexamination of all judges, undertaken during 1999 with international invigilators, and increased the salaries of judges. The law gave the President of Georgia broad powers over the judiciary, especially in the area of appointments.

- Two laws were enacted in October 1998 which govern the transfer of ownership rights on nonagricultural land from the public to private sector. The "Law on declaration of private ownership of nonagricultural land in use of physical and private legal persons" permits sales of privately owned land. The "Law on administration and disposition of state-owned nonagricultural land" regulates the procedure of privatization and leasing of state land.

- The "Law on Securities Market," adopted in December 1998, created a legal basis for a securities market in Georgia. According to the law, a Securities Commission, established in 1999, regulates the market as an independent judicial body. The head of the commission is appointed by the President of Georgia. No transactions have been rejected so far in the securities market.

- The "Law on Accounting and Reporting," adopted in February 1999, determined new accounting standards consistent with internationally established principles and creates an Accounting Standards Commission in the parliament. Under the law, responsibilities for accounting services in the public and private sectors are separated. The law recognizes the Georgian Federation of Professional Accountants and Auditors as a selfregulating professional organization, responsible for development of private sector accounting and reporting based on International Accounting Standards (IAS). Adoption and implementation of IAS is to be overseen by the Accounting Standards Commission, with representatives from the Ministry of Finance, Securities Commission, business sector, academics, etc. The conversion of enterprises to IAS is envisaged to begin January 2000 , although some companies already prepare IAS consistent accounts.

79. Georgia possesses a free press, which can reinforce the role of the justice system in enforcing the rule of law. It is not unusual for the press to report on accusations of corruption and violations of law, even at a high level. Nevertheless, accusations often appear to reflect the agenda of media backers, undermining their credibility. In addition, prosecutions of judges and government officials are extremely rare, even in well-known cases of corruption; in most instances, the penalty is a loss of position or reassignment.

80. The loose interpretation of contracts-particularly the lack of enforcement of hard budget constraints and respect for property rights-has undermined Georgia's financial stabilization and impeded the emergence of a formal market economy. Although Georgia has established political stability and an extensive new legal framework, strict enforcement remains elusive. The following section discusses the difficulties faced in budget implementation, where public sector commitments are not fulfilled on a timely basis. This in 
turn sends a signal to the private sector that non-payment and non-fulfillment of contracts is an inevitable facet of economic life.

\section{The Soft Budget Constraint}

81. Georgia has a history of unfulfilled budgets. During the last three financial years, unpaid domestic budgetary obligations-largely in respect of wages, pensions and social benefits-have cumulated to an estimated level (at end-December 1999) of lari 240 million (just over 4 percent of GDP).

82. The obstacles to budget fulfillment arise on both the revenue and expenditure sides. Weak tax compliance is closely linked to corruption and tax evasion, as well as the extensive shadow economy. Roughly half of the tax revenue that could be raised at existing tax rates is foregone (see Annex I). Effective tax rates on many excisable goods are very low by international standards, in part resulting from political influence and patronage, which at times have been translated into de jure exemptions incorporated in the Tax Code and customs tariff. These sectors include cigarettes, alcohol, fuel products and automobiles. In addition, the limited authority of the central government in some regions facilitates smuggling and hampers the transfer of revenue to the central budget. Likewise, transit across Georgia into neighboring countries, especially of petroleum products, cigarettes and ethyl spirits, is open to potential abuse.

83. Tax arrears are widespread, for example tax officials indicate that only 20 percent of the 600 largest taxpayers pay taxes due in full and on time. However, court cases are rarely successful in recovering unpaid taxes. An official assessment of the ten largest delinquent taxpayers in mid-1999 showed that in four cases enforcement actions envisaged in the tax code had not been taken, in three cases court proceedings had been inactive since 1997 and in one case, a court rejected the request for bankruptcy proceedings. A major factor in the persistent high level of tax arrears (and accrued fines and penalties) is the unwillingness of the authorities to pursue arrears of state enterprises (although, many are not profitable), which is equivalent to issuing a tax preference. ${ }^{35}$

84. Profits from state-owned assets are another source of foregone revenue. In general, state-owned enterprises do not submit dividends or profits to the budget, with the exception of the NBG. Although many state-owned enterprises are not profitable, enterprises which could submit dividends to the budget include the ports, railways, airport, local and international telecommunications, natural gas transit and distribution, oil extraction, and privately managed state-owned hotels. A better managed electricity generation and distribution system could also contribute to the budget rather than being a drain on it. The revenue from state forest is not transferred to the budget, but to enterprises which maintain the forests. The budget did not

\footnotetext{
${ }^{35}$ In some cases, state enterprise arrears result from quasi-fiscal operations such as the provision of free or discounted electricity to a significant proportion of the population.
} 
receive significant license revenue from the issuance of three cellular telecommunications licenses, worth tens of millions of U.S. dollars.

85. Budget constraints also do not operate effectively for many large state-owned enterprises. They have significant accumulated arrears on tax payments, wages and supplier contracts. As described in Chapter VI, the lack of financial discipline is particularly acute in the energy sector where sizeable off-balance sheet liabilities have been accumulated.

86. The difficulties in executing the budget extend beyond shortfalls in revenue. Monthly cash limits for expenditures have not fully reflected revenue shortfalls, with the result that the limits are not fulfilled. In addition, the increase in expenditure arrears cannot be explained by shortfalls of revenue alone. The other explanatory factors include unrealistic monthly cash limits, the offsetting of tax arrears against expenditure arrears, unbudgeted spending and reallocation of funds by spending units. Budget sequestration during 1997-1999 failed to control expenditure sufficiently to avoid the accumulation of expenditure arrears. The Ministry of Finance's monitoring of expenditures is partial, focussing on obligations to spending units, rather than the obligations of the government as a whole to the non-government sector. The problem of expenditure arrears has led to other problems, as unpaid suppliers of the government withhold tax payments, seek offsets that distort the allocation of expenditure, or accumulate arrears to other parts of the economy. Thus, financial difficulties of the government have set the pattern for the economy as a whole.

\section{Legal System Enforcement in Other Sectors}

\section{Enterprise restructuring}

87. The weak court system is an obstacle to enterprise restructuring. The non-enforcement of bankruptcy laws prevents nonviable enterprises from being closed, and prevents resources from being freed for more productive uses. In addition, enterprises with potentially viable components have found that selling part of their assets does not provide them with working capital, as the proceeds are claimed by the tax authorities.

\section{Foreign investment}

88. A weak rule of law is an important obstacle to new foreign investment in Georgia and a nuisance for existing investors. Investors often discover debts not known at the time of due diligence. These may be legitimate debts, or may be partly or completely spurious. Courts are often of little assistance in resolving problems resulting from newly discovered debts.

89. In several cases, court decisions have led to changes of control of enterprises. A court decision reversed the privatization to foreign investors of Chateau Zegaani Winery, which produced export quality wines. The investors have been unable to reverse the decision or obtain compensation. A court decision reinstated the privatization of the Borjomi mineral water factory, Georgia's largest exporter, to its workers. The workers have retained the company which held the management contract and, thus, the interests of foreign investors could be respected. The impact of ongoing judicial reforms (noted above) on private investors 
is not yet markedly positive. While a foreign investor in the telecommunication sector obtained court rulings which effectively transferred a controlling stake of equity from a local partner as compensation for unpaid liabilities, other investors have faced continued interference by the judiciary in areas usually regarded as a commercial prerogative, e.g. orders to reinstate workers fired for corrupt practices.

\section{Land market}

90. One key aspect of the rule of law is a credible register of land property rights, and rapid resolution of property disputes through the courts. Georgia enacted the laws required for agricultural land privatization in 1996 and for urban and industrial land privatization in 1998. Although titles have been issued to land owners able to pay for them, a strong land market began only in 1999, largely due to the lack of an effective land registration system. Another difficulty is that Georgia's courts are flooded with property disputes which are not resolved expeditiously.

\section{Commercial banking}

91. Banking supervision is an area where the application of the rule of law has made much progress. Supervision regulations are clearly specified. However, some significant concerns remain. A local court has undermined the supervisory authority of the NBG by repeatedly suspending the NBG's order to increase the minimum capital requirements of banks. Eventually, however, the NBG's authority to determine the minimum capital requirement-granted under banking sector legislation-was affirmed by the courts in mid1999. Also, a court battle over the ownership of the premises of a bank which had its license withdrawn delayed the liquidation of the bank for a year, preventing depositors from being compensated. The ownership issue has been clarified and the building has been sold. The amount due will be paid in several tranches.

92. The experience of banks with the collection of collateral is mixed. Banks report some success in repossessing apartments and houses through moral suasion. However, of 72 mortgage repossessions examined by a foreign expert, none were procedurally correct. In no case was an asset sold at open tender, as per regulations. 


\section{POVERTY}

\section{Poverty and Income Distribution Profile as of end-1997 ${ }^{36}$}

93. In Soviet times, poverty was not widespread in Georgia. The main reasons were Georgia's relative economic prosperity (supported' in part by favorable terms of trade vis-à-vis other Soviet republics) and the fact that the Soviet system ascribed great ideological importance to the elimination or absence of poverty and thus supported a generous system of social transfers. However, the collapse of the Soviet Union and the breakdown of monetary and trade relations among Baltic countries, Russia, and other countries of the former Soviet Union (BRO), together with an increase in energy prices, took a heavy toll on the Georgian economy. In addition, hyperinflation in 1993-94, together with civil war in Abkhazia and forced migration out of conflict zones, led to a substantial impoverishment of the Georgian population.

94. During 1996-97, the restoration of macroeconomic stability and civil order led to a resumption of economic growth and some marginal reduction of poverty rates (compared to 1994). This occurred mainly in the urban areas, although regional differences in poverty rates and high vulnerability to poverty persisted.

95. Poverty rates (i.e., the percentage of the population below the poverty line) in urban areas declined during 1996-1997, reflecting a recovery in transportation and trade and services sectors in the metropolitan centers. Rates in rural areas remained largely unchanged in 1996/97 with respect to $1992 / 94$, mainly due to the low levels of labor productivity in agriculture. ${ }^{37}$ This said, however, urban poverty remained deeper and more severe than in the countryside. In particular, in 1997, the poverty gap (i.e., the gap between the consumption of the average poor and the poverty line) and squared poverty gap index (measuring the degree of inequality among the poor) in urban areas were 40 and 60 percent, respectively, higher than those in rural areas. The incidence of poverty in rural areas was lower than in urban centers

${ }^{36}$ For 1997 , this analysis draws on the poverty assessment report prepared by the World Bank (Georgia: Poverty and Income Distribution, Report No. 19348-GE) and on household surveys conducted by the State Department of Statistics of Georgia (SDS). The figures reported in this section refer to end-1997 and are based on a poverty line of lari 52 used by the World Bank (see Box 5 for definitions). In the next section, developments over 1998-99 are discussed based on more up-to-date surveys by the SDS.

${ }^{37}$ Between 1990 and 1997, employment in the agricultural sector almost doubled, whereas agricultural output declined by 30 percent relative to its pre-reform level. The agriculture sector was a major employment source for surplus labor shed by industrial enterprises. Productivity in agriculture has remained low because of a lack of fuel, machinery, and capital investment for infrastructure development. Also, severely deteriorated infrastructure and difficult terrain have contributed to a physical isolation of agricultural producers. 
because the rural population had access to land and therefore could achieve higher in-kind consumption. $^{38}$

96. There are wide differences in poverty rates and poverty gaps among the regions, with poverty rates in the richest regions (Samegrelo/Poti, Adjara/Batumi) being half of those in the poorest ones (Imereti, Guria). Differences in poverty rates reflect mainly the regions' initial conditions and hence their differing opportunities for economic growth. In particular, regions with high poverty rates are those areas which were predominantly heavy-industry centers during Soviet times (and which became inactive with the breakup of the Soviet Union) and whose populations have lacked gainful employment opportunities and/or access to land for agricultural self-employment. By contrast, regions with low poverty rates are diversified agricultural and agro-industrial centers, as well as trading centers such as the ports of Batumi and Poti. Geographical differences also play a role. Imereti, with the highest poverty rate, has the highest proportion of the population living in remote, high-altitude areas. Because of lack of road and infrastructure maintenance, many of those areas in the mountainous regions are isolated (i.e., cut off from the market) during winter months.

97. As of end-1997, some 11.1 percent of the total Georgian population were poor, that is, about 600,000 people had a consumption level which was less than the World Bank poverty line. ${ }^{39}$ Of this total, some 120,000 (equivalent to 20 percent of the poor) were chronic poor whereas 80 percent of the poor were transfer poor-that is, they remained poor for only part of the year. ${ }^{40}$ The fact that the average household in Georgia faces a high risk of falling into some form of poverty during the year suggests that average household consumption is highly volatile and therefore the vulnerability to poverty is high. The volatility of consumption is caused by three main factors: (i) the informalization of the economy and hence a lack of stable employment and income; (ii) the seasonality of in-kind consumption, which ranges from about 13 percent of total consumption in the first quarter of the year (winter period) to about 23 percent in the third quarter; and (iii) the limited ability of households to smooth their consumption due to the limitations of the formal and informal safety net schemes (see below).

98. The majority of the chronic poor (73 percent) are concentrated in urban areas with the Imereti region (formerly a heavy industry center) claiming the lion's share of the chronic poor (48 percent) followed by Tbilisi ( 21 percent). This reflects inter alia a high concentration in

\footnotetext{
${ }^{38}$ However, the high proportion of in-kind consumption in total consumption of rural households results in a high sensitivity of rural poverty to the agricultural cycle and weather conditions.

${ }^{39}$ The rate of poverty based on the official (SDS) poverty line of lari 104 was 45 percent in the same period (see also Box 5).

${ }^{40}$ Households go in and out of poverty when their consumption falls below or rises above the poverty line.
} 
urban areas of individuals-such as single pensioners, the disabled, single mothers, and those with serious medial conditions-who are less able to make use of informal coping mechanisms.

99. The Gini coefficient based on monetary incomes was estimated for end-1997 at 0.52. ${ }^{41}$ However, the consumption-based Gini coefficient-which is a more accurate measure of inequality in Georgia given the high level of unreported income and in-kind consumption-was 0.36 in the last quarter of 1997 . The distribution of consumption in Georgia was thus slightly more equal than in Latin America, but less equal than in most central European transition or BRO countries.

\section{Recent Developments}

100. The improvement of poverty indicators observed in 1996-97 was reversed in 1998-99. During 1998-1999, the poverty indicators based on the official (SDS) poverty line worsened (Table 1). The country's average poverty rate (measured against the SDS subsistence minimum basket) increased from 43 percent in Q4 1997 to 58.5 in Q2 1999. Also, the economy's poverty gap (depth) and the squared poverty gap (severity of poverty) increased by 19.2 and 5.9 percentage points, respectively. Moreover, poverty rates in urban center appear to have increased faster than those in the rural areas during 1998 and into the first half of 1999 , probably as a result of the direct and indirect effects of a rapid accumulation on government wage, pension, and social transfers arrears (see below).

101. While poverty indicators based on the World Bank's poverty line (see Box 5) are not available for $1998,{ }^{42}$ one can still conclude that poverty in Georgia increased during 1998 and first half of 1999 , irrespectively of the benchmark used to assess poverty. ${ }^{43}$ In particular, all official poverty indicators (i.e., the economy's average poverty rate and the average depth and severity of poverty) increased during the year. Based on these data, one could argue that many of those who were clustered between the SDS and the World Bank poverty lines at the end of

\footnotetext{
${ }^{41}$ For comparison, the Gini coefficient for per capita income in Brazil, which has a very unequal income distribution, was 0.61 in 1995 . (A value of 1.00 means absolute inequality).

42 The World Bank study provides data only through December 1997.

${ }^{43}$ In the economic analysis, the staff of the SDS has used three basic benchmarks for assessing poverty: (i) a subsistence minimum level of expenditure; (ii) a benchmark equivalent to 40 percent of the median consumption of the population; and (iii) a benchmark equivalent to 60 percent of the median consumption of the population (see Box 5 and Table 1). For Q4 1997, the SDS poverty line drawn at 40 percent of median consumption (lari 40) was comparable to the extreme poverty line or survival basket (about lari 40) used in the World Bank study. The Bank's extreme poverty line was lari 12 less than the Bank's subsistence minimum in Q4 1997.
} 


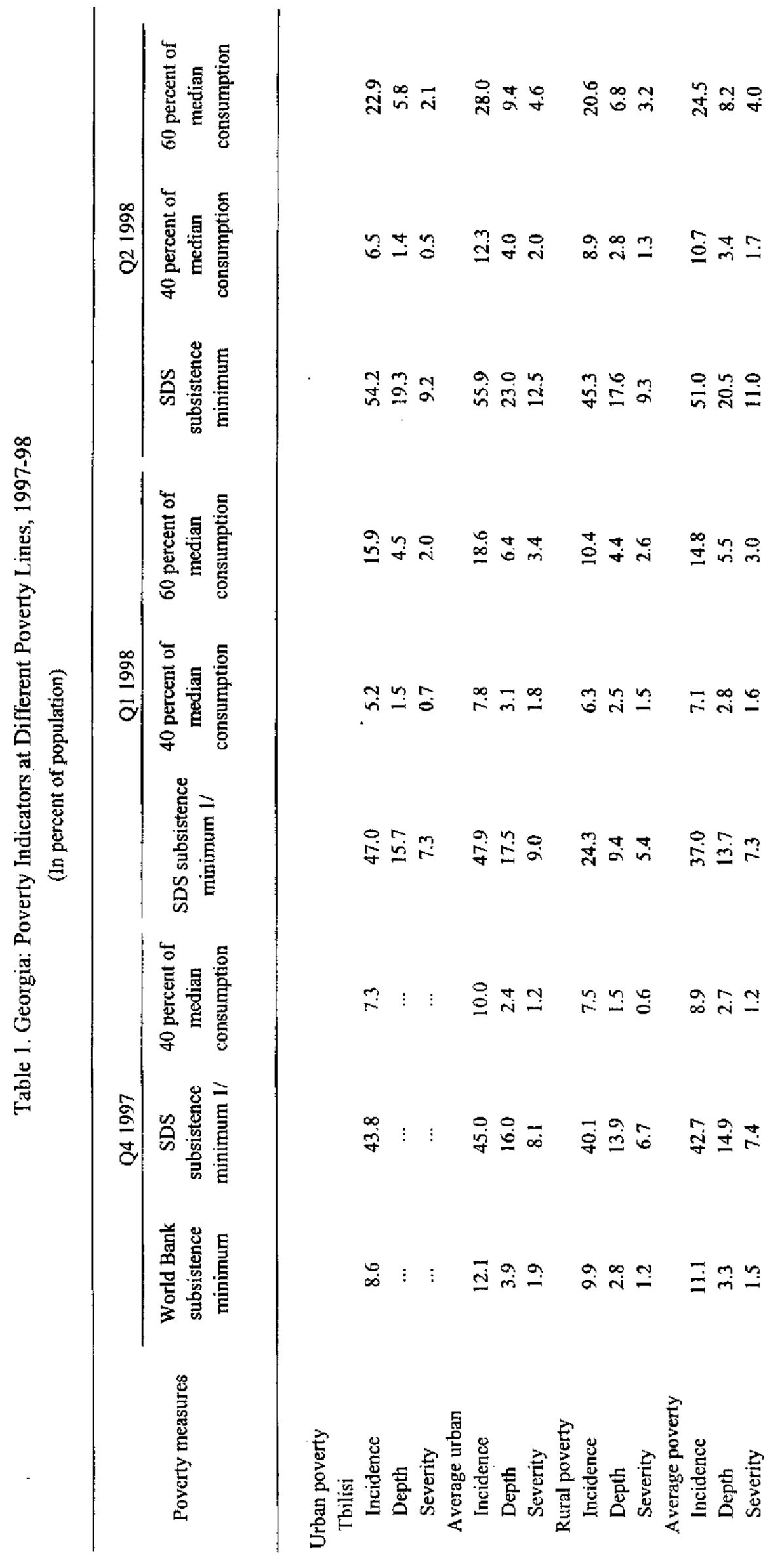


$-43-$

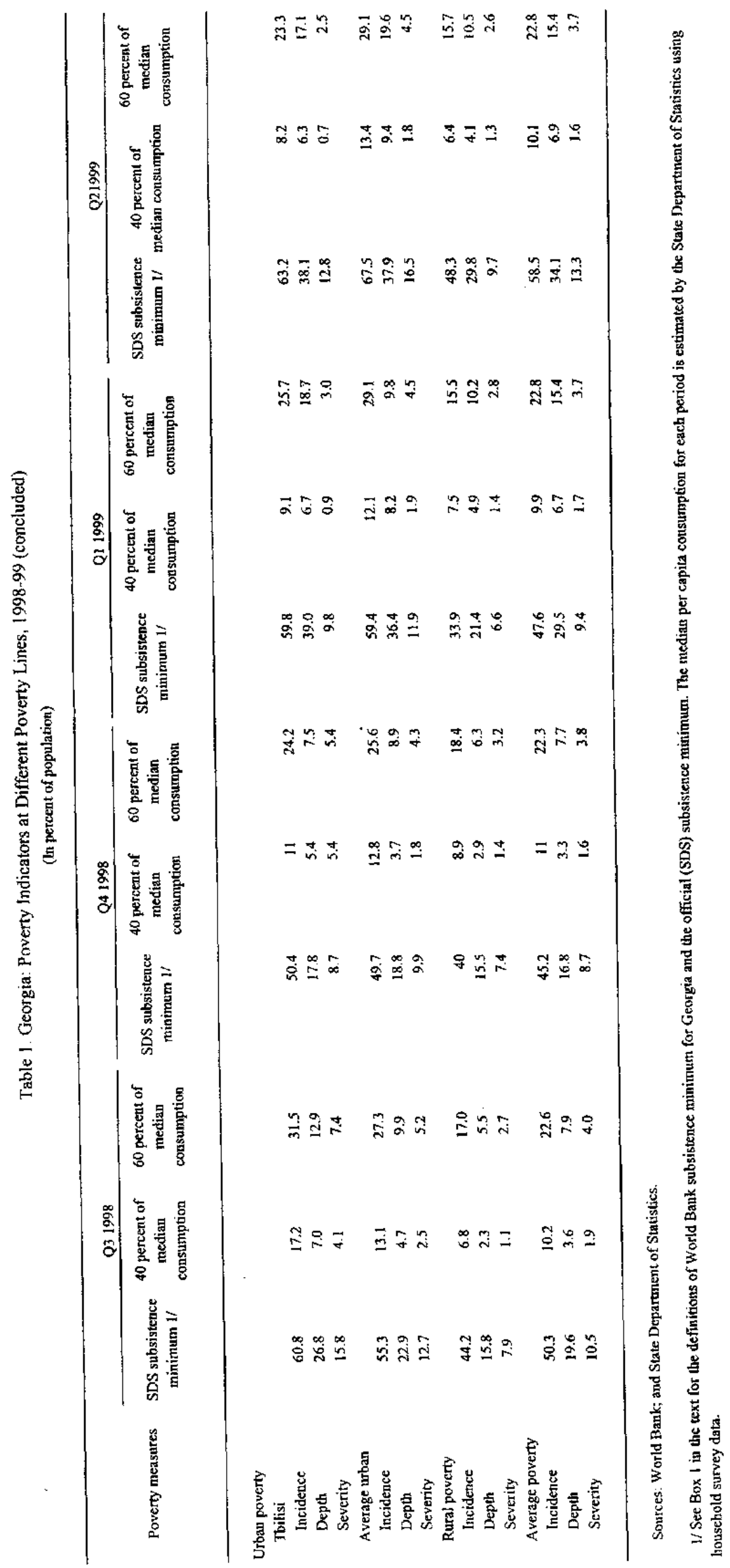


1997-almost a third of the population-must have fallen below the new poverty line between 1998 and mid-1999. Thus, during 1998 and into early 1999, the number of poor unambiguously increased, and the poor became poorer. Three factors help explain the observed worsening of the poverty indicators over this period: (i) the rapid accumulation of wage and social transfers arrears; (ii) a decline in private incomes, possibly caused by a contraction in agriculture and onset of the Russia crisis in late $1998{ }^{44}$ and (iii) a worsening of the income distribution.

102. The level of consumption of low-level budgetary sector employees and povertyvulnerable segments of the population was adversely affected by a rapid accumulation of government expenditure arrears on protected items during 1998-99. In particular, arrears on pension and family allowances increased by lari 36 and 10 million, respectively; wage arrears of local budgets alone increased by lari 16 million in $1998 .^{45}$ As of end-1998, the outstanding stock of arrears on protected items (such as wages, pensions, unemployment and family benefits) stood at lari 140 million and then increased further to an estimated lari 240 million at end-1999. Because of high concentration of budgetary sector employees, pensioners, and the unemployed, the urban areas were the most affected by the nonpayment of wages and benefits. The failure of the State to honor its liabilities resulted in an increased recourse by households to sale of assets and accumulation of debt as a source of cash income (Table 2): the share of consumption expenditure financed by selling assets and borrowing increased from 5 and 9 percent for urban and rural households, respectively, in the first quarter of 1998 to 8 and 13 percent in the second quarter of 1999.

\footnotetext{
44 This is not necessarily a major factor but certainly worsened the situation, as the official poverty indicators were all rising through the third quarter of 1998 relative to end-1997.

${ }^{45}$ Of this amount, lari 9.4 million were new wage arrears to teachers. Given the number of teachers in 1998 (approximately 137,000) and the average teacher salary (lari 45 a month), this implies that on average the actual salary paid to teachers in 1998 was at most lari 39 a month, which was just below the cost of the survival basket (lari 40 ).
} 


\section{Box 5: Definitions of Poverty Indicators}

The poverty line is defined as the minimum subsistence level of consumption. The official subsistence level is based on a food basket of 2,500 calories for a working adult and excludes access to health care or education. The cost of the basket is determined by the SDS based on pre-1992 consumption norms, and varies subject to seasonal and secular trends in the price of the basket components (see chart below). The average value of the official subsistence minimum during 1997-98 was lari 105 (about US $\$ 78$ at the average exchange rate for the period). The World Bank uses a different poverty line based on a food basket of 2,300 calories and the actual consumption patterns of the population. In accordance with international practices, the World Bank's poverty line includes expenditure on health and education based on the actual spending by low income groups. For 1997, the Bank's poverty line was set at lari $52(\$ 40)$. Food expenditure accounts for 70 percent of the Bank's subsistence minimum.

The poor are defined as those individuals who live in households with total average consumption per member of the household below the poverty line. In Georgia, measures of poverty based on monetary income would be misleading due to a large discrepancy between reported incomes and actual consumption. The observed discrepancy (estimated at about 40 percent on average) reflects a high degree of informalization of the economy and persistent under reporting of monetary incomes rather than a drawdown of accumulated cash boldings by households.

The poverty rate (or headcount index) is defined as the percentage of the population below the poverty line.

The depth of poverty (or the poverty gap index) measures how far below the poverty line the consunption of the poor falls.

The severity of poverty (or the squared poverty gap index) measures the degree of inequality among the poor.

The chronic poor are those individuals who stay poor throughout the year. By implication, the chronic poor are individuals who do not benefit from economic growth.

103. Official data indicate that both cash expenditure on consumption and in-kind consumption were lower in 1998 than in 1997 . (Figure 7). These trends contrast with an upward trend for average reported income registered for most of 1998 (although income fell in the final quarter of 1998). A possible explanation of these differences could be that, while total household income declined, the gap between reported and actual (reported plus unreported) income narrowed during most of $1998 .{ }^{46}$ The decline in in-kind consumption has been sharper in rural areas which traditionally rely more on self-sufficient farming. Adverse weather conditions resulted in a 10 percent decline in agricultural output in 1998. Agriculture accounts for about 50 percent of total employment in Georgia. In early 1999, expenditure on

${ }^{46}$ The gap between cash expenditure and reported cash income declined from 41 and 29 percent of reported cash income in the first quarter of 1998 for urban and rural households, respectively, to 26 and 3 percent in the third quarter of the year. Although the gap widened again following the advent of the Russian crisis. Reportedly, the authorities' main motivation for increasing the minimum wage is to reduce scope for under reporting money incomes in the formal sector of the economy. 


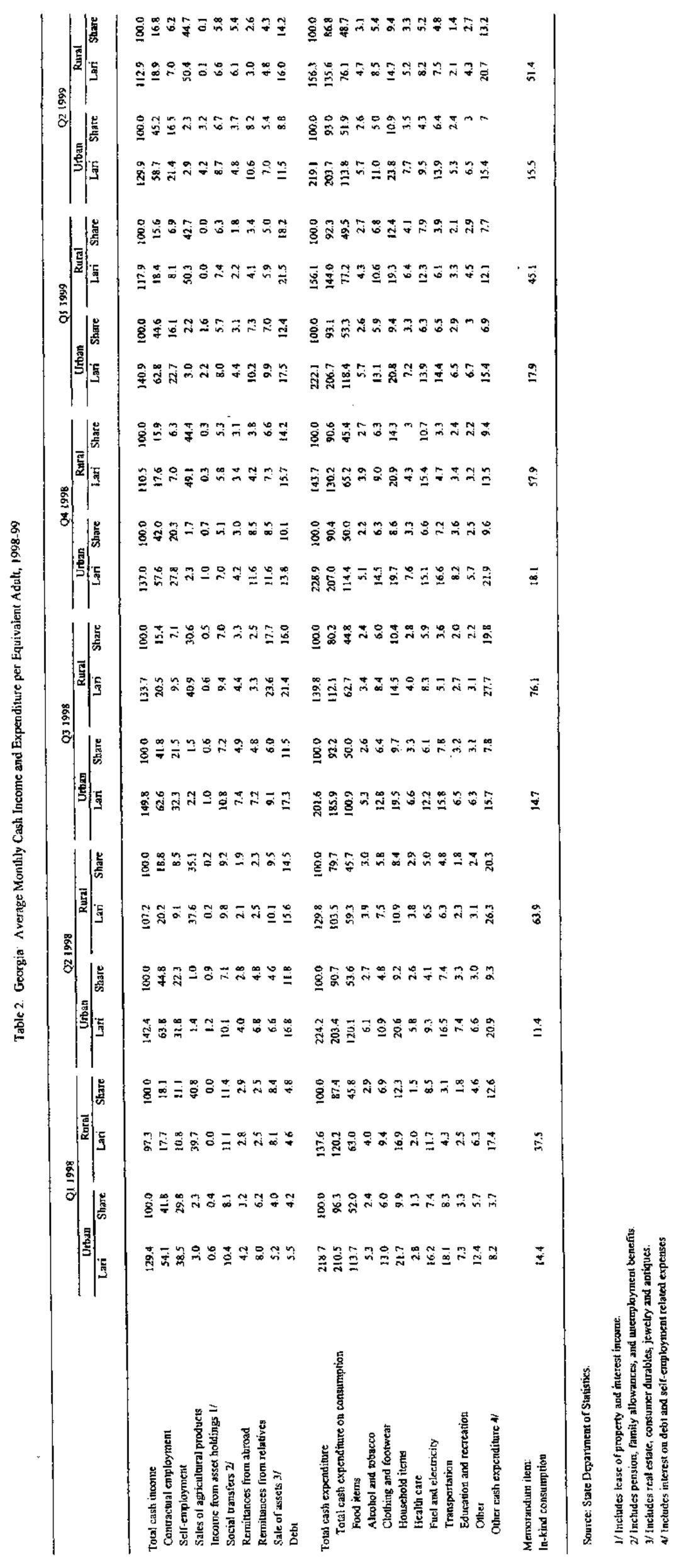


Figure 7. Georgia: Average Monthly Consumption, 1997-99

(In lari)

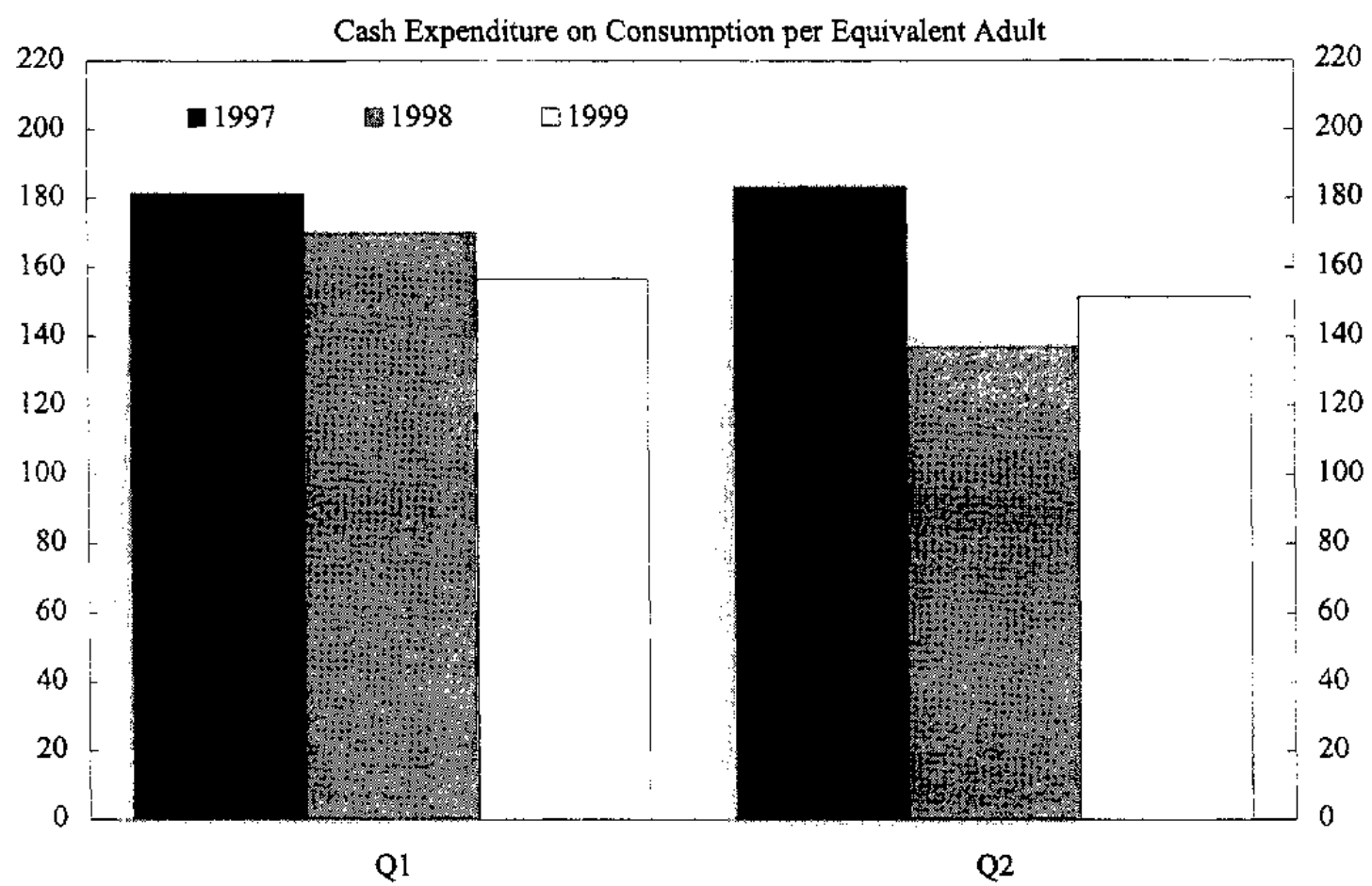

In-kind Consumption

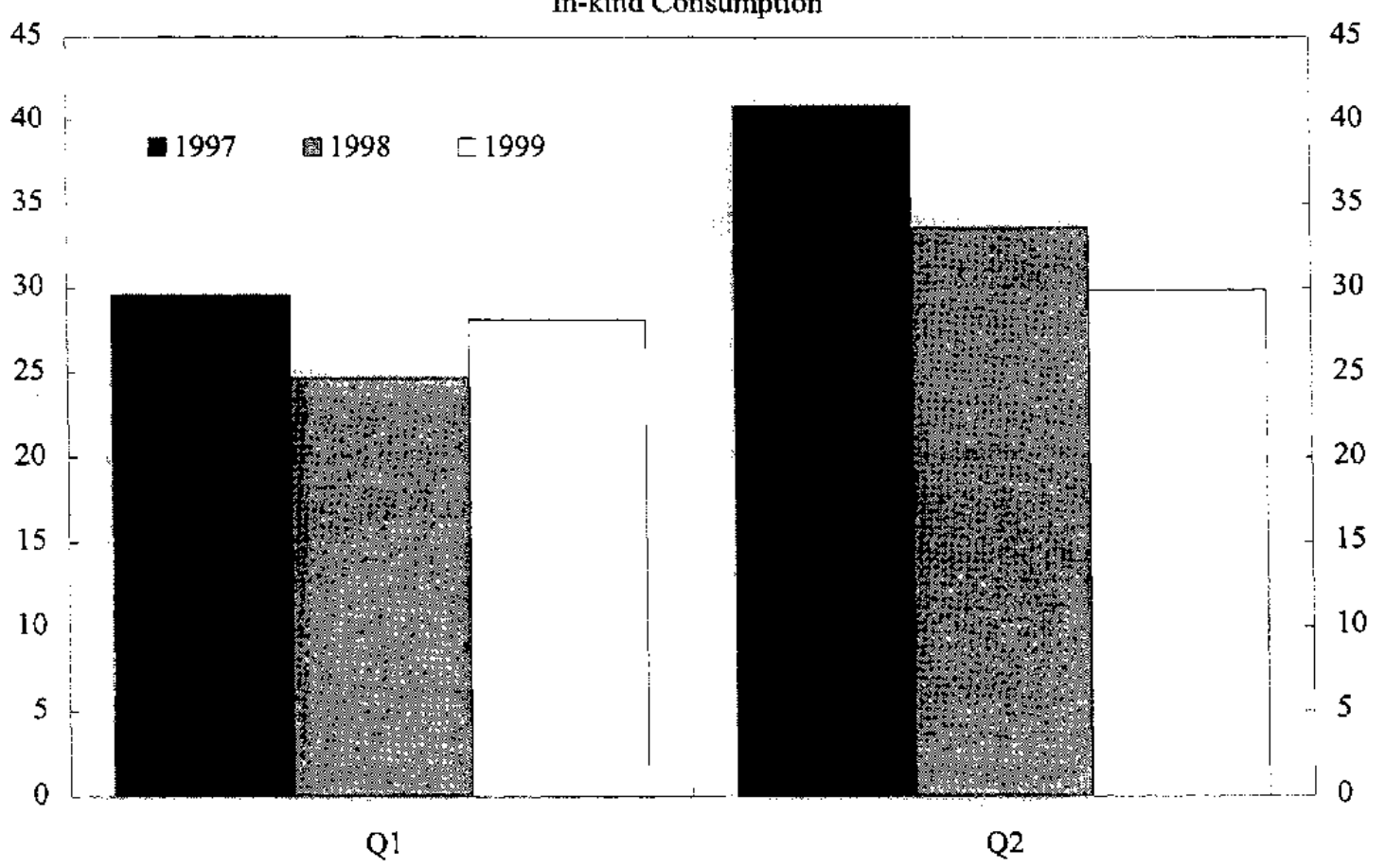

Source: Conjuncture Research Center; and Fund staff estimates. 
consumption in rural areas increased relative to 1998, partly due to some recovery in the agricultural sector.

104. During 1998, there was a marked increase in inequality of income distribution. Official data indicate that the share of the top decile in the total income of the population increased from 34 to 41 percent between the first and third quarters of 1998, whereas the share of all the other deciles declined. The income-based Gini coefficient increased from 0.48 in the first quarter of the year to 0.54 in the third quarter.

105. Taken together, the decline in total consumption relative to 1997 and the deterioration of income distribution imply that the total income of the population most likely declined in 1998 and early 1999 and the richest 10 percent of the population got a bigger share of it. This conclusion is corroborated by the results of a survey of households in Tbilisi conducted in December 1998 by The Conjuncture Research Center. During the survey, households were asked to assess changes in their economic conditions that occurred in 1998, as well as their expectations for 1999. Almost 70 percent of surveyed households believed their economic situation worsened in 1998 , and about 40 percent of the households expected their economic situation to worsen in 1999 . Only 11 percent of households believed that their economic condition improved in 1998 (Figure 8).

\section{Formal and Informal Social Safety Nets}

106. The collapse of the Soviet Union, together with the hyperinflation period of 1993-94, virtually destroyed the system of social benefits provided in Georgia during Soviet times. Since 1995, however, the government has been trying to restore social benefits for the population to meaningful levels. In particular, the pension system, the system of unemployment benefits and family allowances, together with a program aimed at protecting internally displaced persons (i.e., refugees from the civil war) and other transfers to individuals have been put in place in recent years to protect the poor. These formal mechanisms of social protection add to a system of informal coping mechanisms which have emerged to supplement the government programs. The government's ability to finance a formal social safety net has been limited however by a tight fiscal resource constraint in recent years. This, in turn, has resulted in a situation wherein social benefits ${ }^{47}$ (on a commitment basis) have tripled in real terms over the past three years, but still remain approximately 70 percent below the cost of the official survival basket. ${ }^{48}$ Paid cash benefits are even lower because of the low tax revenue collections and poor budgetary execution caused by a widespread tax evasion and inefficiencies of public administration.

${ }^{47}$ Includes family allowances, pensions, and unemployment benefits.

48 The World Bank estimates the cost of the survival basket (or extreme poverty line) at lari 40 per month per equivalent adult. (This amount represents approximately 40 percent of median consumption). 


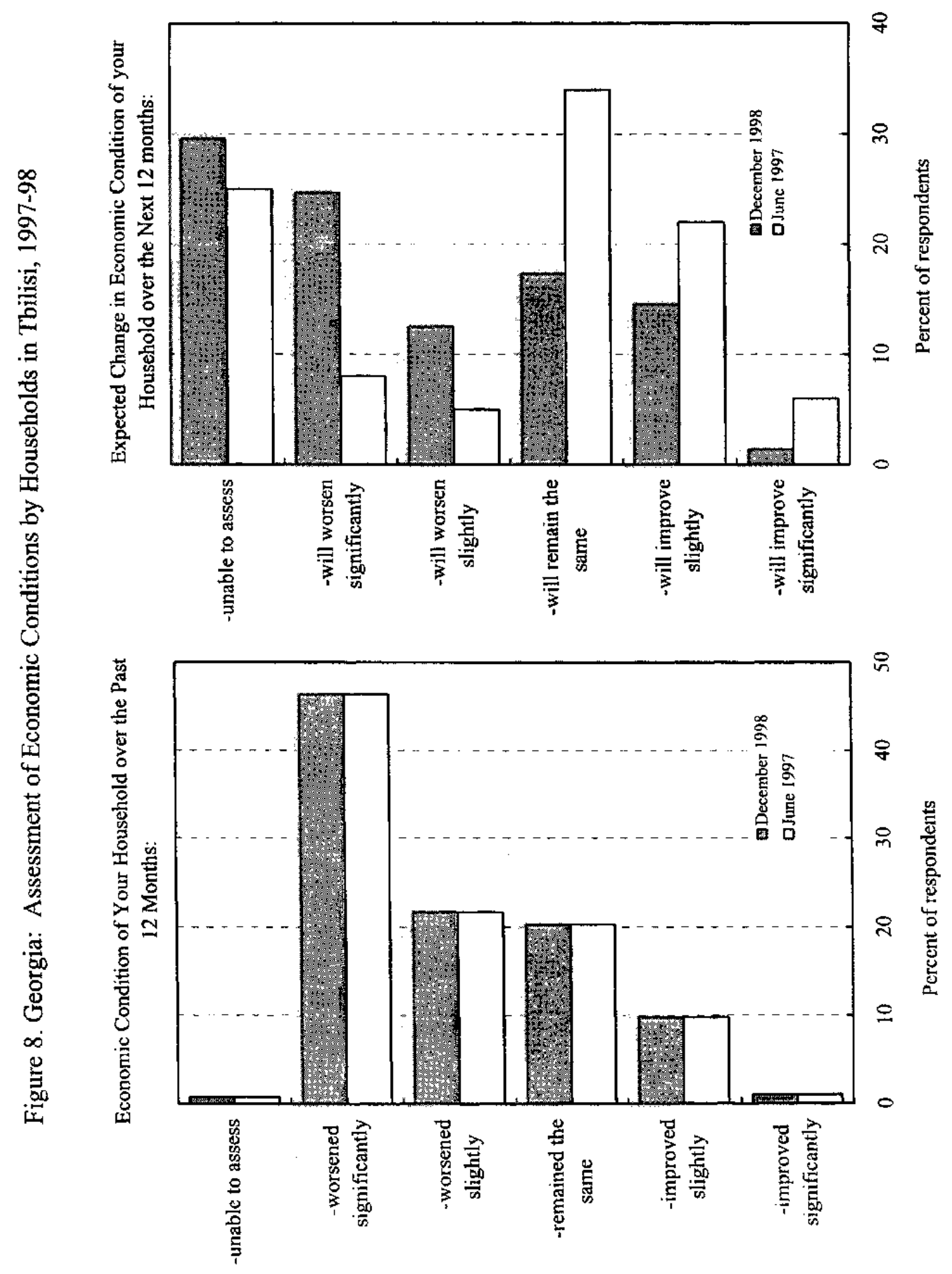




\section{Formal Social Safety Net}

107. Despite significant reforms which limited pension entitlements during 1995-98 (increased retirement age, introduction of a flat pension and elimination of early retirement provisions), the pension fund remains in an extremely difficult financial position and is unable to fully finance a basic pension of US\$7 per month. The pay-as-you-go pension system is financed through a 27 percent payroll tax and a 1 percent employee contribution levied on wages and salaries. This source of revenue, however, covers only about 60 percent of the Pension Fund outlays. ${ }^{49}$ The rest is, in principle, covered by transfers from the central government, although in practice these transfers have generally not been made on time, resulting in an accumulation of pension arrears. ${ }^{50}$ As of end-1998, there were 890,000 registered pensioners, of which 220,000 resided in Tbilisi. ${ }^{51}$ The basic pension benefit received by 817,000 pensioners was lari 14 per month (compared with an official subsistence consumption basket of lari 104). ${ }^{52}$ WWII veterans receive a monthly pension of lari 40 . Disabled pensioners (about 30,0000 ) receive a monthly pension of lari 45 . The responsibility for collecting pension contributions was transferred from the Pension Fund (otherwise known as United Social Security Fund) to the State Tax Inspectorate in October 1998 in an attempt to streamline the tax collection process. Early retirement was eliminated in April 1998. These administrative changes, however, were not sufficient to avert a decline in Pension Fund revenues related to the nonpayment of wages in the budgetary sector and an overall tax revenue decline in the second half of 1998. All pensions are delivered to the recipients by the postal service, with postmen hand-delivering cash to the pensioners.

108. The pension system suffers from a high number of "ghost" recipients and diversion of pension funds at the local level. The latest registration of pensioners revealed 37,743 deceased pensioners "receiving" their pensions. The high cost of funerals forces many people to bury

\footnotetext{
${ }^{49}$ Tax compliance is very low among the self-employed, which accounted for approximately 60 percent of total employment as of end-1998, and especially among those who are occupied in agriculture or engaged in informal economy.

${ }^{50}$ The stock of pension arrears as of end-1997 was lari 9 million. By end-1998, lari 36 million of new arrears ( 2.5 months worth of pensions) were accumulated. Pension arrears are more prevalent in rural and depressed regions which are net recipients of funds from the Pension Fund. Tbilisi, Poti, and the administrative district of Kazbegi are the main net contributors to the Pension Fund. In 1998, Tbilisi accounted for 57 percent of total pension contributions. For the vast majority of net recipients, transfers from the center amounted to 5 to 16 times (in Mestia district) the amount collected on site.

${ }^{51}$ In February 1996, the retirement age was raised from 60 to 65 years for men and from 55 to 60 years for women.

52 A flat pension was introduced in 1995.
} 
their relatives without registering or declaring their death. Postal workers responsible for the delivery of pensions have a clear incentive to retain the pensions of those deceased but not reported. Furthermore, according to the Ministry of Social Security, Labor, and Employment, postal offices oftentimes delay the delivery of pensions for several weeks in order to engage in commercial activities with the recipients' money. ${ }^{53}$ During 1996-97, the average delay was 6 weeks. Reportedly, the misuse of pension funds and delays in delivery escalated in the second half of 1998 when those responsible for delivery reportedly engaged in foreign exchange market speculation.

109. Unemployment benefits are paid for up to 12 months at the rate of lari 13 (less than US\$7) a month. Payments are financed out of the Employment Fund which collects a 1 percent payroll tax contribution. In 1998, the replacement rate-the ratio of the unemployment benefit to the last wage received-was approximately 20 percent. $^{54}$ Individual incentives to register as unemployed with a State Employment Office were weak because of the low level of unemployment benefits, frequent payment delays, time-consuming registration procedures, and a widely held perception that registration is of no help in finding a job. ${ }^{55}$ Furthermore, because of the limited duration of the unemployment benefits, many of those who are currently registered may no longer be eligible. ${ }^{56}$ As of mid-1998, about 50 percent of the registered unemployed were out of work for more than 3 years, and 33 percent of 1 to 3 years. Therefore, only 3.5 percent of the registered unemployed were eligible for unemployment benefit.

110. The family allowances program was introduced in 1997 and was initially intended to cover some 350,000 individuals with a benefit level per person of lari 9 per month. In 1998 , due to a lack of funding, the program was reduced in scope to cover only single pensioners and was renamed into the State Social Allowances program. By end-1998, the number of recipients stood at 56,000 individuals. The actual government spending on family allowances amounted to lari 7.8 million in 1997 (49.1 percent of the budgeted expenditure level) and to lari 4.1 million in 1998 (28.5 percent of the budgeted expenditure).

111. The Internally Displaced Persons (IDP) assistance program comprises various cash and in-kind benefits and is second only to the pension program in size. In 1997, actual expenditures of the state budget on IDP assistance totaled lari 53 million, compared with lari 122 million spent on pensions. As of end-1998, there were 286,000 individuals officially registered as IDPs. According to current legislation, IDPs are eligible for benefits regardless of

${ }^{53}$ The Ministry of Social Security was merged with the Ministry of Health in December 1999.

${ }^{54}$ As of mid-1998, the average monthly wage across the economy was about lari 60 .

${ }^{55}$ As of end-1998, there were 98,000 registered unemployed whereas the number of individuals out of work was estimated at about 300,000 .

${ }^{56}$ Before 1998, the unemployment benefits were paid for up to 6 months. 
their income or asset ownership, which makes the program poorly targeted. Consequently, those refugees who successfully integrated into local communities face a lower than average risk of poverty. ${ }^{57}$ IDPs used to receive a large proportion of foreign humanitarian aid in recent years, but this type of funding is now drying up.

112. In addition to cash benefits, the government provides electricity tariff discounts to two broad categories of households regardless of their actual consumption of electricity, although legislative amendments in December 1999 capped the discounts (see below). The first category-distinguished pensioners, WWII and civil war veterans, and DP's-are eligible to receive free electricity (i.e., 100 percent discount). The second category-tax and customs officials and defense and security personnel-are eligible for a 50 percent discount. According to Telasi, some 4 percent of electricity consumers in Tbilisi are eligible to receive free electricity while an additional 13 percent are eligible for a 50 percent discount. Through 1997 , Telasi (main electricity distributor for Tbilisi) and Sakenergo (electricity distributor for the rest of the country) received transfers from the budget for the amounts of the subsidy. In 1998, however, the transfers were replaced by tax offsets to these companies. In general, these electricity discounts are poorly targeted. For example, war veterans who are eligible for a 100 percent discount receive a monthly pension of lari 40 , compared to the basic pension of lari 14 a month received by 95 percent of pensioners. Moreover, the delivery of the benefit in the form of indirect consumer subsidy is inefficient and distortionary. In December 1999, Parliament passed legislative amendments which replaced discounts for unlimited consumption with fixed amounts of discounted consumption, and eliminated some categories of discounts. This is estimated to reduce the budgetary cost of discounts from about lari 35 million in 1999 to lari 5 million in 2000.

\section{Informal Coping Mechanisms}

113. A number of informal coping mechanisms have emerged to supplement the formal social safety net. Informalization of income sources has affected all Georgian households regardless of income level. The following are the most important coping mechanisms: subsistence farming, petty trade, family support networks, and sale of assets. On average, these informal sources of income jointly represent over 50 percent of all reported incomes of the poor, and at least 30 percent of all reported incomes of the non-poor.

${ }^{57}$ According to the World Bank, this finding is corroborated by the analysis of the SDS household survey data.

${ }^{58}$ The total number of recipients of humanitarian aid has been consistently declining since 1996: from 800,000 in 1996 to 500,000 in 1997 to 350,000 in 1998. According to the Ministry of Social Security, Labor, and Employment, there will be no recipients of humanitarian aid in 1999 due to the drying up of aid. 
114. Subsistence farming has become the main informal safety net in urban areas (titling small family-held plots in the urban periphery). Incomes from agricultural self-employment constitute about 50 percent of total population incomes and over 70 percent of total incomes in rural areas. Petty trade typically involves cross-border buying and selling on a small scale. By end-1997, small-scale trade accounted for about 40 percent of all self-employment in urban areas. Poor families are less likely to engage in petty trade because of the need for a start-up capital and administrative barriers to staying in business which usually have to be settled with bribes and informal payments.

115. Family support comprises intra-family monetary transfers and multigenerational households. Intra-family monetary transfers account for up to 10 percent of total reported incomes of the poor living in urban areas. Regrouping nuclear households into an extended multigenerational household under a single roof has the advantage of exploiting existing economies of scale. For example, if a dwelling is registered in the name of an individual eligible for an electricity tariff discount, the whole family can consume free or subsidized electricity. At present, multigenerational households represent over 50 percent of all households in Georgia.

116. Sale of assets (distress sale) such as housing, consumer durable, jewelry and antiques is used by households as "bridging" source of funds. According to a survey of households in Tbilisi conducted in December 1998 by The Conjuncture Research Center, the average monthly sale of household possessions and real estate totaled about lari 92 per household in the second half of 1998, while average monthly purchases of consumer durables and real estates did not exceed lari 189 (i.e., a net sale of assets of lari 74).

117. Social ties and connections have become extremely important in securing jobs and access to services in addition to the above informal coping mechanisms. The jobs secured via connections usually do not pay much in terms of stated wage but provide access to rents. Because of the importance of the network-based support system, the poor who have little to offer in terms of bribes or connections find themselves increasingly isolated from job opportunities and access to services. Once on the job, connections are also becoming increasingly important for securing timely payments of salaries and wages.

\section{Access to Health Care and Education}

118. Two additional indicators of the magnitude of poverty in Georgia are the very limited access to health care and basic education by households with scarce means. Between 1990 and 1995, public expenditure (in real terms) on health care and education declined by about 90-95 percent with respect to their Soviet time levels. The lack of funds by the Ministry of Health forced the government to separate all health care institutions from the state budget in 1995. Also, resources were no longer available for maintaining buildings and providing school supplies, and school teachers experienced a sizeable decline in their real wages.

119. By mid-1998, the situation with health care had not improved significantly compared to 1995 , with government covering only 30 percent of direct costs (such as medical supplies) 
of health care provision. ${ }^{59}$ The remaining costs have been covered by patients, often times in the form of unofficial gratuities to health care providers to compensate for their low wages. The situation has been further aggravated by a bias in public expenditures inherited from the Soviet times, against preventive health care which would benefit the poor. Specifically, in 1998 , only 8 percent of state budget health expenditures was allocated to preventive health care. The rest was allocated to curative health care which the poor can hardly afford. However, the absolute public health expenditure figure is so low that it is doing little to improve either curative or preventive care: in 1996 for example, 13 out of 15 health care programs carried out by the state were badly underfinanced. ${ }^{60}$

120. The situation with the government education programs is also very difficult. Although primary and secondary education is still free up to the $9^{\text {th }}$ grade, parents have to pay for transportation to school, textbooks, catering, heating fuel, and minor repairs. Many parents are unable to afford these expenses, especially in the rural areas. Consequently, enrollment rates in primary and secondary education fell from 95 percent each in 1990 to 80 and 76 percent in 1994 , respectively. The poor may also have been negatively affected by a skewed allocation of state budget expenditures on education: about 50 percent of executed expenditures goes to financing university education versus 20 percent spent on primary and secondary education (Table 3). ${ }^{61}$

\section{Summary and Conclusions}

121. The initial years of transition in Georgia witnessed a significant impoverishment of the population caused by output collapse, hyperinflation, civil war and forced migration from the conflict zones. The adverse effect of the output collapse during 1991-94 was somewhat mitigated by the informalization of employment and the reallocation of labor out of industry and into small-scale low-productivity agriculture and trade.

\footnotetext{
${ }^{59}$ Notably, depreciation is not included anywhere in the cost calculations. The Ministry of Health estimates that in Tbilisi alone US\$8 million a year is needed to upgrade and rehabilitate the health care facilities to allow them to provide services they claim they provide. The lack of maintenance leads to deterioration of hospital equipment and infrastructure, increased safety hazards, and further contributes to the decline in public health.

${ }^{60}$ For example, the AIDS prevention program was financed for just 25 percent of the estimated cost, whereas the population immunization program was financed for only 32 percent.
}

${ }^{61}$ Primary education is mainly financed by local governments. The remaining allocation of state-budget expenditure on education is to "special funds" for education. These include expenditures by universities and schools from fees they have received, e.g., private tuition and renting of space. 


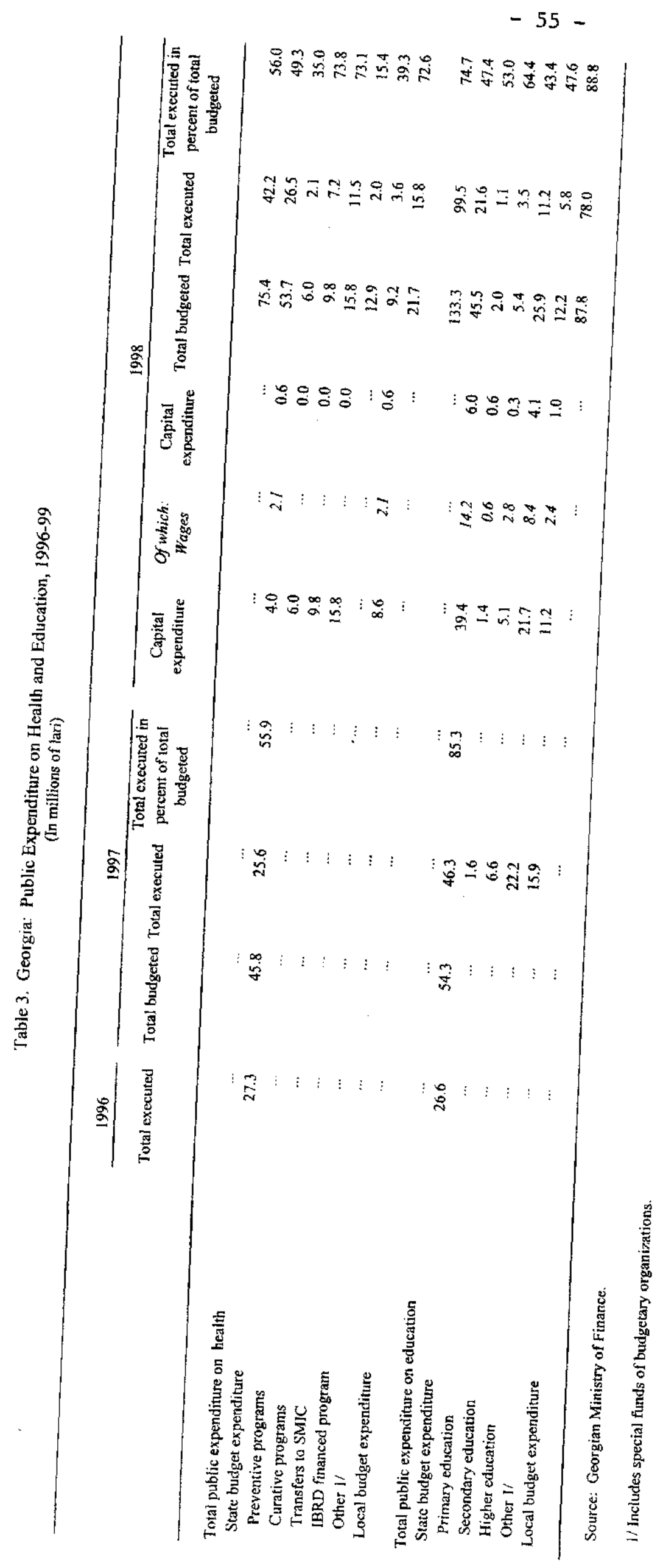


122. The poverty indicators improved during 1996-97, especially in the urban areas, when economic growth resumed in Georgia following the restoration of macroeconomic stability and civil order. The positive trend was reversed however in 1998 owing largely to a decline in agriculture, which provides an informal safety net to the population, and the accumulation of wage and social expenditure arrears. The recent experience in Georgia has also shown that opportunities have been created for well connected segments of the society while other segments of the population have seen their living standards, equality of opportunity, and economic mobility eroded.

123. The predominantly transient (as opposed to chronic) nature of poverty in Georgia implies that poverty can be alleviated by creating a "bigger and better" social safety net (which would allow households to smooth their consumption and thus to reduce their vulnerability to poverty) and by setting the economy on a non-inflationary growth path. Accordingly, the role of the government should aim at ensuring macroeconomic stability, peace and civil order, and to create legal and market conditions conducive to private sector development, including infrastructure rehabilitation and development as well as an appropriate level of investment in human capital. Well-targeted and cost-effective expenditures-such as those for primary education, basic public health care, and rural infrastructure-should be efficient tools for providing the poor with opportunities to escape from poverty. Redirecting health and education expenditures in Georgia from hospital treatment and university education to preventive health care and primary education would increase access of the poor to health care and education.

124. As noted above, some social assistance programs-such as refugee benefits and electricity tariff discounts-have been poorly targeted and do not represent cost-effective social safety nets. Improving the targeting of refugee benefits, stepping up efforts to reintegrate refugees into local communities, and eliminating in-kind benefits such as electricity tariff discounts would reduce the burden on the budget, improve resource allocation, and ensure a more equitable provision of social benefits. It is important to build an institutional capacity to manage and deliver services effectively to the poor. Better tracking and registering recipients as well as monitoring the use of funds at the local level would help prevent diversion of funds and payment delays.

125. Creating a "bigger" safety net would call for raising social benefits-such as pensions, unemployment benefits, and family allowances-to meaningful levels in relation to the subsistence minimum. The ability of the government to do so is severely circumscribed by the fiscal resource constraint. Even the small size of the social benefits at present have imposed significant budgetary burdens which proved to be unsustainable because of the low tax revenue collections to date. Broadening the payroll tax base, inter alia, by bringing the informal sector into the tax net and enforcing tax compliance would enhance revenues of the social funds and generate resources for paying adequate pensions and social benefits to all eligible recipients without delay. 


\section{BANKING SECTOR}

126. Since 1994, the Georgian authorities have embarked on a comprehensive program of banking sector restructuring. The banking sector reforms-which focused on upgrading and enforcement of prudential standards for commercial banks - have started to yield positive results, particularly with regard to banking system consolidation. In addition, financial indicators suggest that the banking system, assisted by strong preventative measures exercised by the NBG, was able to weather the stress test supplied by the Russia crisis.

127. Despite the progress made so far, the overall role of banks in intermediation remains very small, with a ratio of broad money to GDP of only 8 percent (Table 4). In addition, dollarization is rising, which suggests a lack of confidence in the lari. As a result, continued banking sector reform, with a view to increasing financial intermediation for the mobilization of savings for productive investment, will be important for Georgia's sustainable economic growth.

128. This chapter provides an overview of recent banking sector developments with particular focus on prudential regulation and draws some policy conclusions for further development of the banking system.

\section{Overview of the banking system}

129. The banking sector has undergone a substantial consolidation since 1994; however, there are still too many banks relative to Georgia's population. ${ }^{62}$ The introduction of bank prudential standards, generally in line with the Basle guidelines, together with vigorous enforcement of the regulatory framework by the NBG, led to a sharp reduction in the number of banks, from a peak of 229 in early 1994 to 38 by end-December 1999. Of the 38 remaining licensed banks, 13 banks account for 80 percent of the assets.

130. The banking system comprises resident regional small and medium-sized banks, a handful of large banking institutions with branch networks, and two foreign banks. The former state banks (FSBs), which once held monopolies over national savings, export/import financing, and agricultural sectors, are no longer the single players in any particular sector. Following an international audit, two of the three FSBs have successfully undergone a fundamental restructuring, including laying off a substantial number of workers and closing unprofitable branches, thus improving their net worth to well in excess of the statutory minimum. However, the remaining former state bank, Agrobank, continues to have significant financial difficulties.

131. The share of the former state banks (FSBs) in financial intermediation has continued to shrink-from 39 percent of total assets at end-1996 to about 33 percent as of July 1999 -

${ }^{62}$ For instance, Sweden, with a population of 8.8 million, had 13 commercial banks in 1995 . 
Table 4. Georgia: Developments in the Commercial Banking System, 1995-99

\begin{tabular}{|c|c|c|c|c|c|}
\hline & 1995 & 1996 & 1997 & 1998 & 1999 \\
\hline Number of commercial banks & 101 & 61 & 53 & 44 & 38 \\
\hline Former state owned & 3 & 3 & 3 & 3 & 3 \\
\hline Other domestic & 98 & 58 & 50 & 40 & 33 \\
\hline \multirow[t]{2}{*}{ Foreign branches } & 0 & 0 & 0 & 1 & 2 \\
\hline & \multicolumn{4}{|c|}{ (In millions of lari, end-of-period) } & \\
\hline Assets of commercial banking system & 232.6 & 237.9 & 341.0 & 478.1 & 618.6 \\
\hline Loans of commercial banks & 149.0 & 128.2 & 172.9 & 238.2 & 327.2 \\
\hline Lari & 62.7 & 83.2 & 95.9 & 83.8 & 92.3 \\
\hline Foreign exchange & 86.2 & 45.0 & 77.0 & 154.4 & 234.9 \\
\hline Deposits of commercial banks & 57.7 & 82.0 & 133.2 & 156.3 & 200.6 \\
\hline Lari & 34.7 & 43.7 & 55.3 & 48.9 & 42.1 \\
\hline Foreign exchange & 22.9 & 38.3 & 77.8 & 107.4 & 158.4 \\
\hline \multirow[t]{2}{*}{ Household deposits of commercial banks } & 10.4 & 20.0 & 44.1 & 42.7 & 66.4 \\
\hline & \multicolumn{4}{|c|}{ (In percent of GDP) } & \\
\hline Assets of commercial banking system & 9.6 & 6.3 & 7.6 & 10.0 & 11.1 \\
\hline Loans of commercial banks & 6.1 & 3.4 & 3.8 & 5.0 & 5.8 \\
\hline Deposits of commercial banks & 2.4 & 2.2 & 3.0 & 3.3 & 3.6 \\
\hline \multirow[t]{2}{*}{ Household deposits of commercial banks } & 0.4 & 0.5 & 1.0 & 0.9 & 1.2 \\
\hline & \multicolumn{4}{|c|}{ (Annual percent change) } & \\
\hline Loans of commercial banks & $\ldots$ & -14.0 & 34.9 & 37.8 & 37.4 \\
\hline Lari & $\ldots$ & 32.7 & 15.3 & -12.6 & 10.1 \\
\hline Foreign exchange & $\ldots$ & -47.8 & 71.1 & $100.51 /$ & 52.1 \\
\hline Deposits of commercial banks & $\ldots$ & 42.1 & 62.4 & 17.3 & 28.3 \\
\hline Lari & $\ldots$ & 25.9 & 26.5 & -11.6 & -13.9 \\
\hline \multirow[t]{2}{*}{ Foreign exchange } & $\ldots$ & 67.2 & 103.1 & 38.0 & 47.5 \\
\hline & \multicolumn{4}{|c|}{ (In percent) } & \\
\hline Loan to deposit ratio & 258.2 & 156.3 & 129.8 & 152.4 & 163.1 \\
\hline Lari & 180.7 & 190.4 & 173.4 & 171.4 & 219.2 \\
\hline Foreign exchange & 376.4 & 117.5 & 99.0 & 143.8 & 148.3 \\
\hline \multicolumn{6}{|l|}{ Memorandum iterns: } \\
\hline Broad money (M3, in millions of lari) & 180.6 & 256.3 & 373.0 & 368.5 & 444.6 \\
\hline In percent of GDP & 7.4 & 6.8 & 8.3 & 7.7 & 7.9 \\
\hline Currency outside of NBG (in millions of lari) & 124.8 & 176.8 & 239.9 & 212.2 & 244.0 \\
\hline In percent of broad money (M1/M3) & 69.1 & 69.0 & 64.3 & 57.6 & 54.9 \\
\hline In percent of GDP & 5.1 & 4.7 & 5.3 & 4.4 & 4.4 \\
\hline Nominal GDP (in milkions of lari) & $2,432.2$ & $3,768.0$ & $4,504.7$ & $4,794.6$ & $5,593.8$ \\
\hline
\end{tabular}

Source: National Bank of Georgia.

1/ Excluding the effects of the devaluation of the lari at end-1998, foreign exchange denominated loans would have increased by 30 percent. 
mainly since dynamic private banks have been able to successfully attract domestic deposits and benefit from foreign credit lines, and to a lesser extent due to the write-off of bad loans by the FSBs.

132. Foreign banks are not well represented - two foreign banks (a Turkish and Azerbaijan one) are currently operating in Georgia-in part reflecting the small size of Georgia's financial market. However, foreign investment is significant, accounting for approximately one third of total bank capital. ${ }^{63}$

133. Deposits in the banking system have increased nearly four fold since $1995 .{ }^{64}$ However, the level of deposits remains disappointingly low at only $31 / 2$ percent of GDP. The majority of these deposits are short-term time deposits of the business sector. Household deposits remain small-about 1 percent of GDP_-but have been increasing as a share of total deposits, rising from about 18 percent in 1995 to 33 percent as of end-December 1999.

134. Dollarization increased between 1995 and mid-1998, despite a reduction in inflation, suggesting that although confidence in the banking sector has been growing (evidenced by growing deposits), there is a lack of confidence in the lari. The situation was further aggravated by the Russia crisis in mid-August 1998 along with widespread publicity surrounding the weak budgetary position. The share of foreign exchange denominated deposits in total deposits increased from 40 percent in 1995 to 64 percent by mid-1998, and then increased further to 69 percent by end-1998 following the Russia crisis. Dollarization continued to rise in 1999 , reaching 79 percent of total deposits.

135. The low level of bank deposits in the economy may reflect several factors: (i) the memories of hyperinflation in 1993/94, which wiped out households savings; (ii) the relatively large size of the informal economy, estimated at about 25 percent of economic activity in Georgia by the State Department of Statistics; operators in this market are afraid to show their wealth; ${ }^{65}$ (iii) harassment by tax authorities of businesses that have deposits in banks, often blocking and/or sequestering the banks deposits without a clear motive; and (iv) the relatively

${ }^{63}$ Most of the foreign participation in the domestic banking industry reflects injections (by foreign firms and individuals operating in Georgia) into existing Georgian banks before end-1996. A main factor explaining these capital injections was the tax holiday for foreign investments in the domestic banking system (in place through end-1996) and the expectation of lucrative insider lending to equity holders.

${ }^{64}$ This is in lari terms, so it reflects exchange rate changes; U.S. dollar denominated deposits more than doubled.

${ }^{65}$ An estimate made several years ago by the central bank suggested that 45 percent of printed money does not enter the banking system. It appears that there is also a large amount of U.S. currency in circulation and that many large transactions take place in dollars (e.g., those involving liquor, tobacco, real estate, and automobiles.) 
high share of agriculture is also a factor as this sector is typically less monetized (relying more on barter trade) than other sectors of the economy.

136. Assets of the banking system have been rising and the maturity of loans has been gradually lengthening, reflecting lower inflation and access to foreign credit lines. ${ }^{66}$ Bank lending grew by 35 percent in 1997, slowed in 1998 following the Russia crisis, and then resumed growth in 1999. The share of long-term lending in total credit increased from 7 percent at end-1995 to 23 percent by September 1999. In addition, there has been a significant increase in foreign exchange lending in bank's portfolios, increasing from 58 percent of total lending at end-1995 to 72 percent in December 1999. This reflects increased dollarization and banks' desire to pass foreign exchange risk on to their clients.

137. The share of loans to the non-government sector amounted to only 5 percent of GDP in 1999, in part due to the low level of deposits and limited access to foreign capital in the sector. Most of bank financing is concentrated in the trade sector (Table 5), although there has been some increase in the share of financing to industry. Consumer lending is not developed, reflecting in part, deficiencies in risk assessment, collateral, and credit resources.

Table 5. Georgia. Composition of Bank Loans by Economic Activity, 1996-99 (In percent of total loans, end-of-period)

\begin{tabular}{lcccc}
\hline & 1996 & 1997 & 1998 & 1999 \\
\hline Government Sector & 18.2 & 11.4 & 9.6 & 10.6 \\
Trade & 0.4 & 0.0 & 0.2 & 1.1 \\
Industry & 5.2 & 3.6 & 2.7 & 0.5 \\
Construction & 0.5 & 0.4 & 0.2 & 1.0 \\
Communication & 0.1 & 0.3 & 0.1 & 3.4 \\
Agriculture & 2.5 & 1.0 & 0.7 & 0.5 \\
Culture & 0.7 & 0.3 & 0.1 & 0.0 \\
Transport & 0.8 & 0.5 & 0.8 & 0.2 \\
Energy & 1.8 & 1.5 & 2.6 & 1.1 \\
Other & 6.2 & 3.9 & 2.3 & 2.8 \\
& & & & \\
Non-government Sector & 81.8 & 88.6 & 90.4 & 89.4 \\
Trade & 63.1 & 70.4 & 62.9 & 61.4 \\
Industry & 4.7 & 9.3 & 18.8 & 17.3 \\
Construction & 3.0 & 3.1 & 4.5 & 5.9 \\
Agriculture & 11.1 & 5.9 & 4.2 & 4.8 \\
\hline Soure: & & &
\end{tabular}

Source: National Bank of Georgia

138. The shortage in the supply of credit is reflected in high real interest rates at about 20 percent, which may tend to allocate investment toward greater risk. In addition, lending

${ }^{66}$ Foreign credit lines consist of funds from the international financial institutions and international organizations, including TACIS, the EBRD and the World Bank; Georgian banks have difficulty accessing global capital markets. 
practices, while improving, are not well developed and the allocation of loans is not always based on economic criteria. Another obstacle to lending is that the use of collateral is very limited and banks have significant obstacles to seizing property. ${ }^{67}$

139. Although the level of lending rates gradually declined between end-1996 and mid-1998, interest rate spreads continued to remain relatively high, at about 25 percent. Following the onset of the Russia crisis, spreads increased somewhat, as lending rates increased, ${ }^{68}$ and have since edged downwards (Figure 9). The high interest rate spreads may reflect, first, a lack of competition which inhibits efficiency, reflecting the dominance of a few large banks in the sector. Competition is also constrained to some extent by the lack of foreigners entering the market, as they may view the Georgian market as too risky, and, in any event, too small to be worth the risk. Recent efforts by the NBG to publish data on interest rates may help competition. Second, high spreads may reflect the high credit risks, compounded by difficulties to liquidate collateral of delinquent borrowers, which in turn are a reflection of insufficient progress in enterprise and legal reforms. Third, the high reserve requirement (16 percent as of December 1999) is costly to banks, although mitigated somewhat by a remuneration of 10 percent in 1999. Fourth, the existence of too many banks may lead to high overhead costs of the banking system on account of the small scale of their operations. Fifth, banks may be trying to increase their capital base in order to meet the higher minimum capital requirements.

\section{Banking supervision and prudential regulation}

140. The NBG has made much progress in the area of banking supervision and prudential regulation, bringing its requirements more in line with Basle requirements (see Appendix I, Table 30). The law governing the central bank (the Law on the NBG) was enacted in September 1995. Legislation controlling the creation, supervision, and resolution of commercial banks and other credit institutions was passed in February 1996. According to the law, the NBG has the power to issue banking licenses, publish prudential regulations, and supervise banks both off and on-site. In addition, the NBG has the power to take the necessary measures and/or sanctions when problems arise and close cooperation with foreign supervisory authorities is clearly noted.

141. Over the past few years, a number of measures have been taken to strengthen prudential regulation. By end-1997, all commercial banks had at least one on-site examination by the NBG, $\mathrm{CAMEL}^{69}$ ratings were assigned and revised bank licensing procedures were

${ }^{67}$ See Chapter III.

${ }^{68}$ This may reflect the high level of dollarization.

${ }^{69}$ CAMEL (capital, assets, management, earnings and liquidity) ratings are from one to five and are used to rate the financial health of a bank. A "five" rating signals that a bank is in critical condition and may need to be liquidated. 
Figure 9. Georgia: Commercial Interest Rates, 1995-99

(In percent)

Interest Rate Spreads 1/

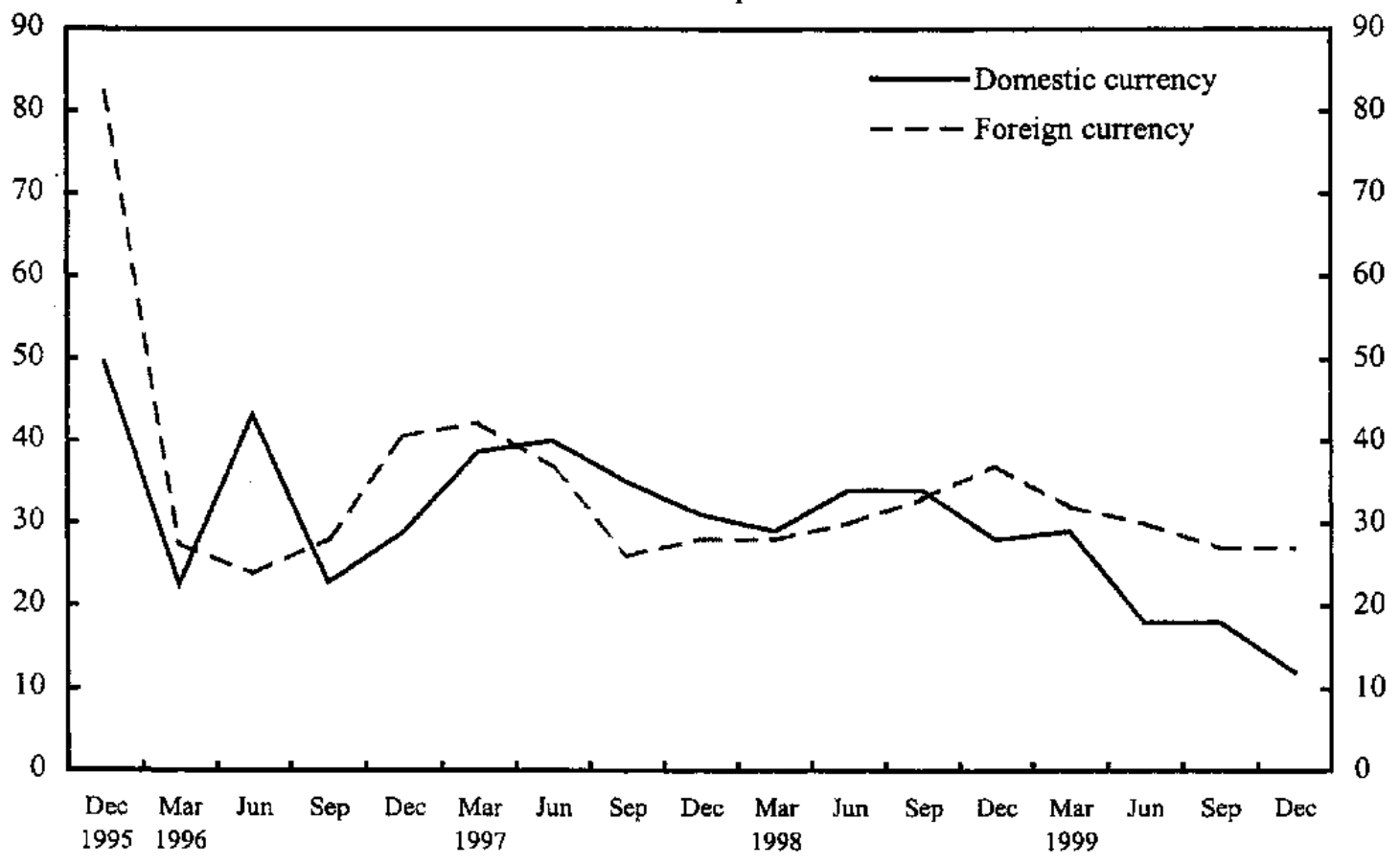

Lending Rates

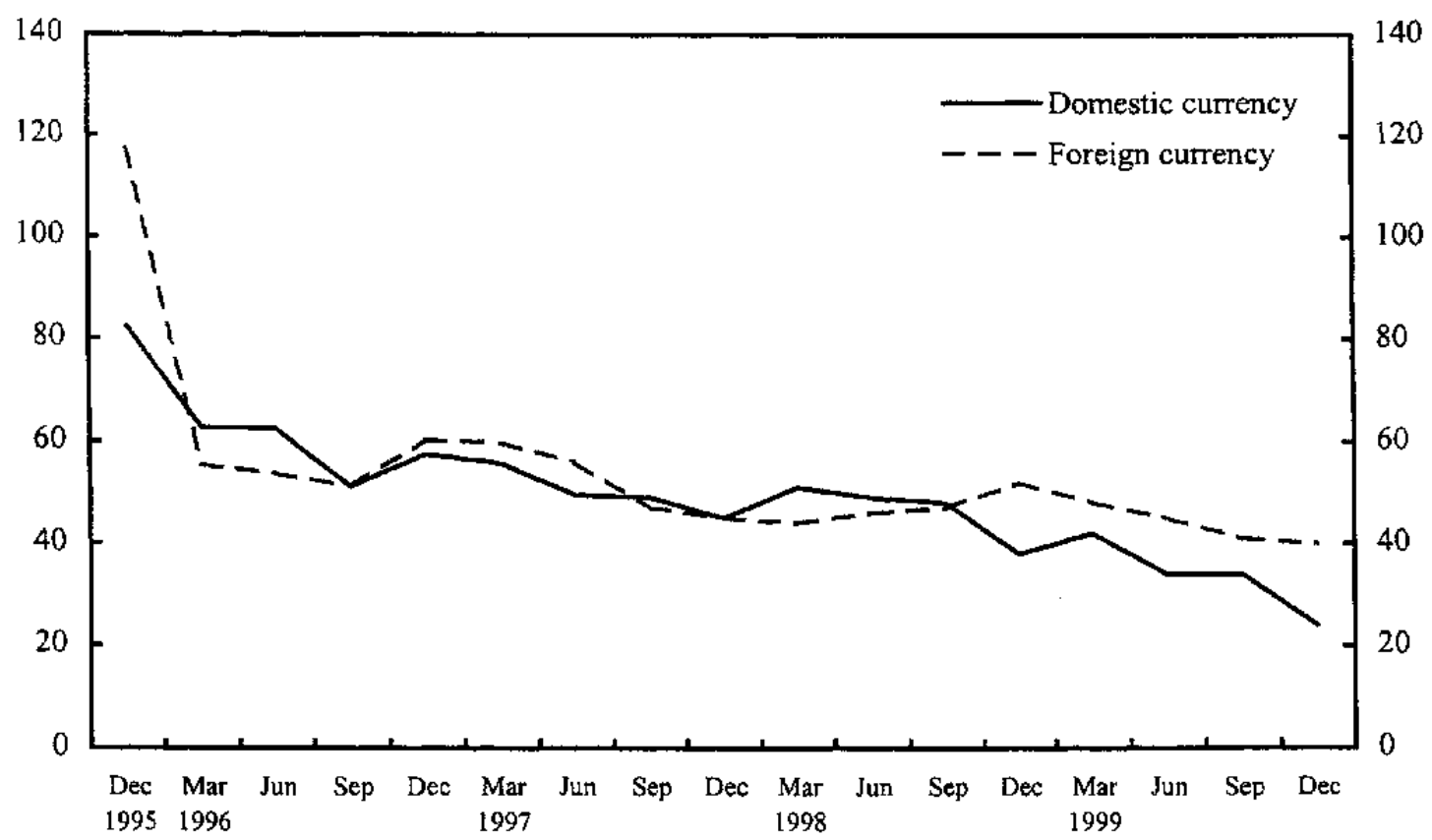

Source: Georgian authorities.

1/ Difference between 3-month lending and deposit rates. 
introduced in 1998. Minimum capital adequacy requirements were strengthened from 10 percent of total assets to 12 percent of risk-based assets for tier 1 capital and 15 percent for total capital. This is a more restrictive requirement that the minimum acceptable level required by the Basle committee. Annual external audits by international auditors were mandated as of February 1, 1999 and starting in end-January 1999, a supervisory action framework was implemented for monitoring banks in financial distress. The framework provided a set of prompt corrective actions to address and resolve weaknesses speedily as they arise. The intention of the legislation was to increase the number of recovered banks and to reduce the number of liquidations. In March 1999, the NBG's licensing and banking supervision departments were merged.

142. Under an established timetable, the NBG will raise the minimum authorized capital requirement to 5 million lari by January 1, 2001 in an effort to strengthen and consolidate the banking system. ${ }^{70}$ As of September 1999 , the average amount of capital in the sector was only about lari $3 \frac{1}{2}$ million, with only five banks meeting the lari 5 million minimum capital requirement. Under the timetable, the increase in the minimum capital requirements would be phased in. In June 1999, the minimum capital requirement was raised to lari 2 million. Subsequently, the NBG faced some difficulties in implementing the higher capital requirements when several banks attempted to challenge the right of the NBG to delicense them in the courts. However, as a result of a favorable court ruling in September 1999, the NBG was able to proceed with de-licensing one of the banks.

143. Prudential indicators (Table 6) suggest that banks maintained a high capital-asset ratio over the period 1996-December 1999 at about 30 percent (the minimum Basle requirement is 8 percent). In the aggregate, banks remained liquid through the crisis with a liquidity ratio (liquid assets relative to total liabilities) of $44 \frac{1}{2}$ percent, versus the prudential minimum requirement of 30 percent. $^{71}$ Banks' net foreign exchange exposure was long during 1998. This was the case during the crisis, and as such the main exposure of banks to the lari devaluation was the second round effect, i.e., loan repayment. While the share of nonperforming loans increased 1999, it remains low at only 7 percent, although this may be suspect due to measurement problems on account of weak accounting practices.

\footnotetext{
${ }^{70}$ The minimum authorized capital requirement was raised to lari 5 million in July 1998 for newly founded banks. Already functioning commercial banks must increase the minimum authorized capital to lari 5 million by January 1, 2001.

${ }^{71}$ Only two banks required a liquidity loan at the beginning of 1999 , as a result of the adverse effects of the Russia crisis. The total amount of the loans was lari 4 million.
} 
- $64-$

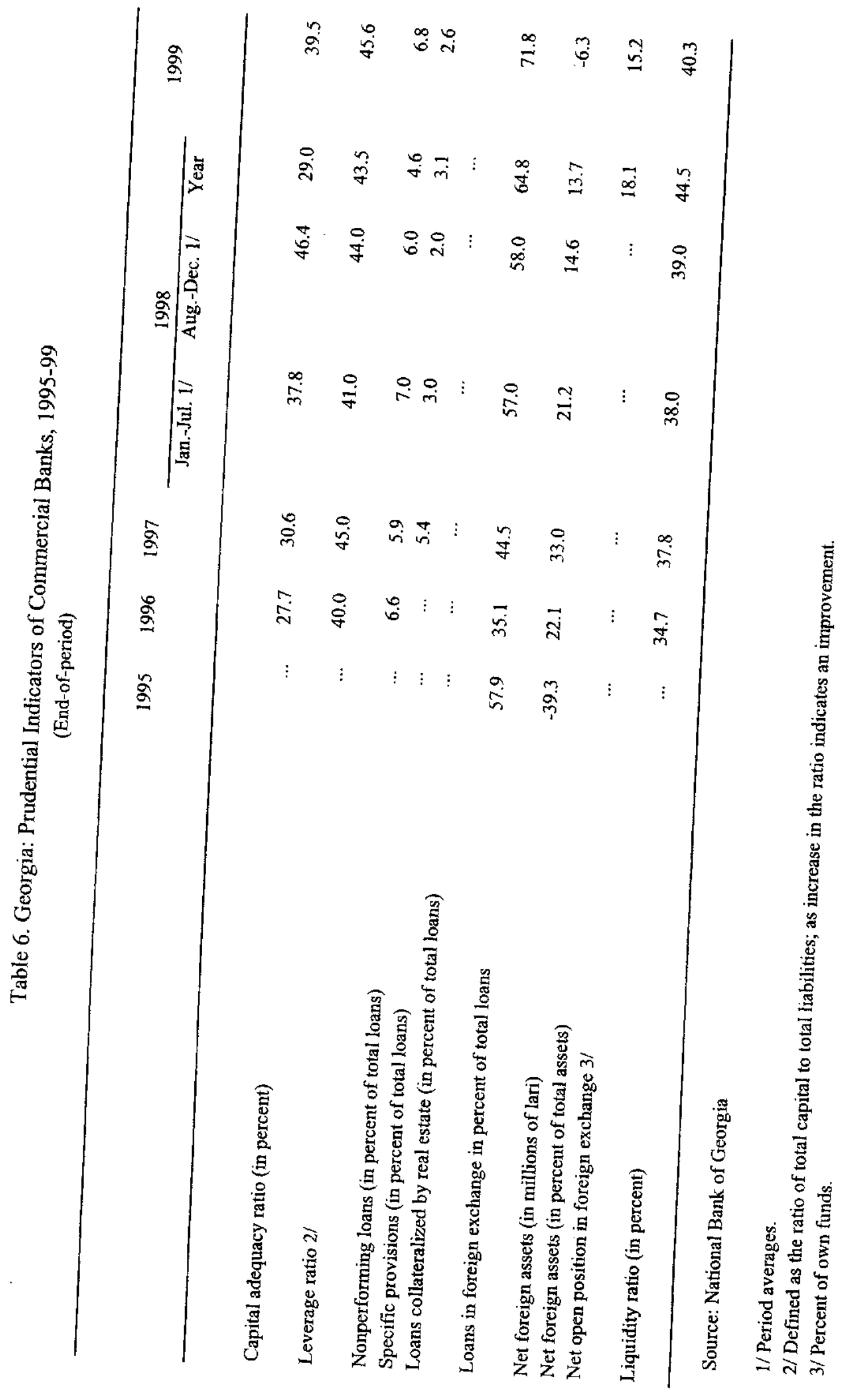




\section{Agricultural credit unions ${ }^{72}$}

144. Presently, there are 144 agricultural credit unions operating in Georgia, covering 10,181 members with a total share capital of lari 2.4 million. Agricultural credit unions are specifically excluded from the scope of law on commercial banks. Local farmers have very limited access to lending from commercial banks, reflecting several factors: the inability to mortgage land, high cost of lending, and inexperience of commercial banks in assessing risk in agricultural lending. To address this, the government in conjunction with the World Bank has undertaken a five year agricultural development plan which has as one of its main objectives the establishment of agricultural credit unions. Agricultural credit unions can provide an important source of mobilizing savings in the rural areas, reducing the need for collateral, and reducing transaction costs.

145. The legal framework for the organization of agricultural credit unions is defined under Article 60 of the Law of Entrepreneurship. In addition, a presidential decree issued on September 16, 1996, established a credit union development center (CUDC) under the framework of the Coordinating Group for the Georgian Agriculture Development Project (CGGADP). The CGGADP's main objectives are to facilitate their establishment, provide legal expertise in their registration in the courts, help with operational procedures, offer technical expertise (training of staff), monitor compliance with the law. Credit unions may join the project on a voluntary basis. They may also borrow funds from the CUDC if they meet specific requirements. There is a system of CAMEL rating, but it is not for public use.

\section{Treasury bill market}

146. The treasury bill market, which began in 1997, reached a total issuance of close to lari 23.3 million in mid-1998 (about 5 percent of total assets in the banking sector). However, widespread concerns about the weak budgetary position and the onset of the Russia crisis had an adverse impact on market sentiment, and the authorities, unwilling to pay higher interest rates, stopped conducting auctions in September 1998. The entire stock was retired in December 1998. ${ }^{73}$

147. The auctions resumed in August 1999 but the small amount offered were sold at below market rates. ${ }^{74}$ In October 1999, the 91 day treasury bill was reintroduced, with an issuance of

\footnotetext{
${ }^{72}$ Gocha Lapauri, an economist in the Resident Representative office, contributed to this section.

${ }^{73}$ Prior to the crisis, the outstanding stock was concentrated in 91-day maturity bills, most of these were owned by commercial banks, with around 10 percent owned by non-banks, including nonresidents who held a small amount, peaking at about lari 1.7 million in early 1998.
}

${ }^{74}$ The acceptance by banks of interest rates which are artificially low was motivated by a technical change in reserve requirements implemented in July 1999 which allowed banks to 
lari 0.9 million and an average interest rate of 15.8 percent. In November 1999, the continued weak fiscal position forced the authorities to reduce issuances below announced levels and 91day treasury bills were discontinued for the remainder of 1999. In addition, the government resorted to direct borrowing from the banking system, which undermined the treasury bill market. As of end-December 1999, there had been no participation in the market by domestic nonbanks and non-residents since the market was resumed.

148. A secondary market for treasury bills existed before the onset of the Russia crisis, but it lacked a clear venue for bringing buyers and sellers together, contributing to its lack of development. In 1999, the NBG implemented legislation to allow the TICEX to be the venue for the market.

\section{Conclusions}

149. The Georgian authorities have made strides in strengthening bank supervision. The banking system was able to weather the Russia crisis, assisted by prompt action on the part of the NBG. However, monetization of the economy remains very limited. Deposits, although increasing, remain very modest and dollarization has risen significantly. Consequently, it will be important to continue with efforts to strengthen the banking system and improve the supervisory capability of the NBG. In addition, the government will need to push ahead with the implementation of other reforms, such as bankruptcy laws and land reform, to create a conducive environment for business.

\section{THE ENERGY SECTOR}

150. This section provides an overview of developments in Georgia's electricity, natural gas and oil sectors, as well as oil and gas transit pipelines. In particular, it emphasizes the recent efforts to reform the energy sectors.

151. The energy sector in Georgia has faced several challenges: (i) the inheritance of a distorted and low energy price system following the breakup of the Soviet Union; (ii) the collapse of the economy following the breakup; and (iii) a civil war that disrupted the fuel and energy network. The situation has gradually improved since 1994. A new regulatory framework has been elaborated and a privatization program has been developed, which has attracted private capital into the sector. However, energy supply is still erratic, particularly in the power sector, and the conditions necessary for its financial recovery have yet to be implemented.

152. Building momentum for reforms in the energy sector is essential. Energy shortages, which have not disappeared, are a major constraint for sustainable economic growth, and feed popular dissatisfaction. Corruption in the sector is persistent. The sector as a whole has

hold one-eighth of their required reserves in treasury bills. Remuneration of reserves was set at 10 percent in 1999. 
accumulated a considerable amount of debt. Given its geographic location, Georgia could be a potentially important player in the transit trade offered by the Caspian Sea region's important reserves of hydrocarbons, which could provide revenues needed to rehabilitate the sector and strengthen the fiscal position.

\section{The power sector}

153. Electricity is the major energy source, although it has been through a number of crises that have severely affected its viability. Power shortages have had a dramatic impact and have proved to be extremely disruptive, creating severe hardship as well as economic dislocation. In the winter of 1998/99, Tbilisi had only 4-6 hours of electricity per day while the rest of the country received an average of 3-4 hours.

154. Georgia has a generation capacity of about 5,000 megawatts (MW) of which two-thirds is supplied by hydroelectric generation. Overall, generation capacity consists of two thermal power plants (TPP) and approximately sixty large, medium and small hydro power plants (HPP). Because of its mountainous terrain and hundred of rivers, the hydro resource potential is considerable; however, according to World Bank estimates, only 11 percent of these resources have been developed so far.

155. In principle, generation capacity should be able to largely cover domestic demand. However, due to years of poor maintenance, deterioration, cannibalization and lack of funds to upgrade physical plants, only 15-30 of generation facilities percent are operational and some of them may be damaged beyond repair. In addition, three of the country's major hydropower stations are located on the conflict zone of the Abkhazian border. For the past ten years, power generation has declined from 15 billion $\mathrm{kWh}$ to about 8 billion $\mathrm{kWh}$. The infrastructure crisis has been much more dramatic in the thermal generation sector than in the hydrogeneration sector. Thermal plants lack operating funds necessary for fuel purchase. As a result, electricity supply is far from meeting the country's demand on a 24-hour basis. The cost of upgrading these facilities is over US\$1 billion according to World Bank estimates. ${ }^{75}$

156. The regulatory framework of the sector has been considerably strengthened. The Ministry of Fuel and Energy was created in 1996 to implement and coordinate government policies, while ownership of sector assets was assigned to the Ministry of State Property Management. In 1997, the passage of the Electricity Law considerably improved the legal and regulatory framework needed to facilitate the privatization of the sector. The law created the Georgian National Electricity Regulatory Commission (GNERC) as an independent, semijudiciary legal entity, funded by license-fees and with administrative autonomy. The Commission has adopted a transparent tariff methodology, both at the wholesale and retail level, based on the principle of cost-recovery. It also has the authority to issue, revoke, and

\footnotetext{
${ }^{75}$ World Bank, Energy Sector Unit, Georgia Country Unit, Europe and Central Asia Region, 1997, Georgia Power Privatization, Report No. 17152-GE, (Washington, D.C.).
} 
modify licenses to sector enterprises. A debt commission was created by presidential decree in order to restructure the liabilities of the sector's enterprises in view of their future privatization. It is composed of officials of the Ministry of Finance, the Ministry of Fuel and Energy, and the Ministry of State Property Management.

157. Poor cost recovery is still crippling the power sector mainly because collection rates are at an inadequate level and prices are too low. Increasing rates will not benefit the sector if they are not combined with an improvement in collection practices. End-user tariffs have increased to 7.1 tetri per $\mathrm{kWh}^{76}$ (3.7 U.S. cents) but are still insufficient to cover long-run marginal costs and do not make provision for the repayment of foreign loans. Average retail collection rates for the sector (excluding commercial losses and supplies to Abkhazia and Ossetia) have also improved from 20 percent to about 68 percent in 1997, but then decreased to 51 percent in 1998 , and to 43 percent for the first four months in 1999 . Limits to improving collection rates include soft-budget constraints, corruption, and an inefficient billings and collections system. Transmission losses at over 15 percent are considered well above technically justifiable norms. In addition, special discounts and allowances, some inherited from Soviet times and some more recently introduced, are provided to more than 230,000 customers. These discounts were not programmed in the state budget and the sector had to bear the costs. Moreover, about two-thirds of these benefits are directed to segments of the population that are not considered at a disadvantage. At current tariffs, these discounts amount to at least lari 28.9 million or about US\$15.2 million. In December 1999, a presidential decree capped the use of free or discounted electricity to a specific level, and it is implicitly assumed that the financing would come from local budgets unless specified in the central budget.

158. Reflecting poor cost recovery, the power sector has experienced chronic financial deficits which amounted to about 5.5 percent of GDP in 1998 and an estimated 6.5 percent in 1999. The accumulated overall debt is estimated at around US\$632 million, as of the end of August 1999. The deficit has been financed with external and internal credits as well as arrears. Part of the debt has been contracted since 1994 from international multilateral and bilateral financial institutions or governments, (IBRD, EBRD, OECF, KfW, Russia) and amounts to US\$260 million. Most of the debt is on concessional terms, i.e., with low interest rates, a generous grace period, and an extended maturity (15-40 years). The loans have been primarily used for rehabilitation of major hydro-generating facilities and for working capital (fuel reserves badly needed for thermal generation at the Tbilsresi TPP). Another part of the debt is composed of tax and wage arrears, as well as debts to private foreign creditors and suppliers, many of which are not included in financial statements.

159. In response to the power sector's acute crisis, the government launched a comprehensive privatization program with the aim of attracting strategic investors with substantial capital and operating experience in the sector. As a prerequisite, the monolithic vertically integrated state enterprise, Sakenergo, was separated into generation, transmission,

${ }^{76}$ Weighted average. 
and distribution enterprises to allow for greater transparency and foster competition. However, the distribution sector was separated into 70 municipal units, an excessive number of entities that cannot benefit from economies of scale and are prone to political interference. Sakenergo continues to exert influence over the sector through its role as the wholesale trader of energy for distribution companies and major direct users (large manufacturers), as well as for import and export of power. This has allowed Sakenergo to act in a way more typical of centrally planned economies, particularly by allowing non-monetary transactions at the wholesale level. In 1998, less than 18 percent of transactions were made in cash, up from 16 percent in 1997 , and the rest was conducted through offsets and barter transactions. In 1998, total amount of cash revenue from the sale of energy was less than the fuel cost for the year. In 1998, Electrogadatsema was separated from Sakenergo to manage and operate its transmission assets. Both are in the process of being transformed into joint-stock companies.

\section{A plan to privatize Georgia's major power facilities as well as its distribution} companies is currently under way (transmission assets will be privatized later). About 50 percent of the distribution companies have been privatized and generation plants (except in Abkhazia) are in the process of being privatized, have been sold or leased to the private sector. The Tbilisi distribution company, Telasi, which was the first entity in the power sector to be successfully privatized was sold in December 1998 to AES, an American utility investor, which acquired a 75 percent stake in the company for US\$25.5 billion. Telasi's importance, given that it accounts for half of the distribution load, and its place at the end of the nonpayment chain sent a clear signal to encourage the privatization process in the power sector. Following this, a tender was announced in May for the right to manage or buy the Gardabani state district power station which has a capacity of 1,500 MWh (about 35 percent of the sector's total capacity.)

161. An component of the privatization process has been the creation in July 1999 of a Wholesale Electricity Market (WEM). It is composed of electricity producers, suppliers and customers and its main task is to facilitate wholesale electricity trade in a transparent and equitable way. The WEM manages financial settlements and flow of funds in the electricity market and ensure that electricity supplies are consistent with payments.

\section{Natural gas}

162. Natural gas was the single most important energy source in Georgia until the breakup of the Soviet Union. In 1989, it represented over 70 percent of the country's primary energy use, most of which was imported from Russia, Turkmenistan and Azerbaijan. After the breakup and beginning in 1992, prices rose by 2,500 percent, which had a severe impact on the economy. By 1995, the sector accumulated a large amount of external debt, primarily to Turkmenistan. The country's gas consumption fell from 5.4 billion cubic meters (BCM) in 1990 to an estimated $0.8 \mathrm{BCM}$ in 1998 . Since domestic production is not significant (0.3 BCM in 1998), most of the gas consumed is now imported. Since 1996, all imports have come from Russia through a single supplier, Itera, an affiliate of RAO Gazprom Russia, which is also a shareholder in the newly-privatized gas companies. 
163. Most of the imported gas is used for power generation (at the Gardabani TPP) and by a few large industries (such as the Rustavi metallurgic plant and the Azoti chemical plant). Supply to households and commercial customers in the cities has been reduced to very low levels. This is due in part to the fact that there is no effective metering, billing and collection system. In addition, prices are too low to generate the revenues that would be sufficient to restore the system to financial health and technical losses remain very high. An estimated investment of over US $\$ 250$ million would be needed to rehabilitate the distribution and transmission system.

164. As has occurred in the power sector, the natural gas sector was separated into transmission and distribution enterprises. Transmission is operated by the state-owned transmission operator company, Saktransgasmretsvi. It will not be privatized until the transit potential has been clarified. Distribution is organized around 29 gas distribution companies, six of which were privatized in 1998. Tbilgazi, the Tbilisi distribution company, was offered for tender for 75 percent of its shares in November 1999. There are also a number of wholesale suppliers.

165. The management of the high pressure gas pipeline system was turned over to the recently created state-owned Gas International Corporation of Georgia (GIC). In addition, it is in charge of promoting and negotiating gas transit projects. Gas transit essentially consists of Russian gas exported to Armenia at about 1.5 BCM per year.

166. The authority of the GNERC has been extended, through amendments to the 1997 Electricity Law, to induce greater competition in the sector and to attract private investment with the aim of restoring gas supply to consumers. The authority of the Commission will include regulation of monopolistic components of gas supply through the transmission and distribution network. It will be in charge of establishing a clear methodology for setting tariffs for monopoly services and will issue licenses to participants in the supply chain. Following this, the remaining 23 municipal gas distribution companies will be offered for privatization.

\section{Oil sector}

167. The already modest domestic potential of the oil sector has been restrained by a lack of security in the legal framework. The amount of foreign investment has been small by international standards (about US\$60 million since independence).

168. The passage of the new Oil \& Gas Law in May 1999 is expected to boost development and attract foreign investors. It established a one-stop regulatory authority for the sector, with powers to negotiate contracts, sign agreements and issue licenses. It provides legal clarity necessary to attract foreign investment in particular in production-sharing agreements. Saknaftobi, the state-owned Georgian Oil Company, will focus on its commercial activities and will cease to play a regulatory role, to avoid potential conflicts of interest. It is in the process of being prepared for privatization. 


\section{Oil and gas transit pipelines}

169. Georgia's geographic location between the Black Sea, Russia, and the Caspian region, rich in hydrocarbons, gives it important potential in terms of energy transit. Georgia's ratification of the Energy Charter Treaty may contribute to realizing that potential, and transit fees could bring substantial revenues to the state. However, because pipelines are long-term projects requiring significant investment inputs, a stable climate is needed, particularly in the tax regime, in order to attract private investment.

170. Georgia signed an agreement with the Azerbaijan International Operating Company (AIOC) to transport oil from the Caspian sea basin to build the so-called "early oil" pipeline. It was completed in April 1999 and has since been transporting oil from the offshore Chirag field via Baku in Azerbaijan to the Black sea terminal of Supsa at a rate of 150,000 barrels per day. The Georgian International Oil Corporation (GIOC) was created by presidential decree in 1996 as the counterpart to AIOC to oversee the Baku-Supsa oil pipeline and to facilitate other oil pipeline projects. Other pipeline routes are under consideration; they would create a main East-West transit energy corridor. At the end of 1999, a package of agreements was signed by the presidents of Azerbaijan, Georgia, Turkey and Turkmenistan in Istanbul on the creation of the Baku-Tbilisi-Ceyhan pipeline. The cost of this project is estimated at between US $\$ 2.4$ billion and US $\$ 4$ billion. It would transport oil from the Caspian Sea region to world markets from Baku in Azerbaijan, to the Turkish Mediterranean seaport of Ceyhan via Georgia. Parallel to this, a gas pipeline, the so-called "Trans-Caspian" pipeline, would be laid across the floor of the Caspian sea from Turkmenistan to Turkey via Azerbaijan and Georgia. Estimates put the cost of this project between US $\$ 2$ and US\$3 billion. Projects have been hindered mainly by the financing component as well as geopolitical interests.

\section{Conclusion}

171. Georgia has made progress in reforming its energy sector although the problems in this sector remain large. It is one of the few countries of the former Soviet Union that sold an electricity distribution company to a strategic investor. A comprehensive privatization program is under way but may be slowed down by the problem of debt contracted directly or indirectly by energy entities, in particular in the power sector. Corruption is another important factor in this slowdown.

\section{EXCHANGE, TRADE AND PAYMENTS SYSTEMS}

172. Georgia accepted the obligations of Article VIII, sections 2, 3, and 4 of the Fund's Articles of Agreement of December 20, 1996.

\section{Exchange arrangements}

173. The currency of Georgia is the lari. The lari became the sole legal tender on October 2, 1995, replacing the coupon, which had been introduced on April 5, 1993, and was declared the sole legal tender on August 3, 1993. For all commercial transactions, the exchange rates of the lari are negotiated freely between the banks and foreign exchange bureaus that are licensed by 
the NBG, and their customers. In addition, the NBG and the major commercial banks participate in the sessions at the TICEX on each working day. Auctions take place for any currency as long as the bid is not less than US\$5,000. At these sessions, all transactions take place at the single exchange rate for each currency which balances supply and demand.

174. Between January and August 1996, the official exchange rates for the U.S. dollar and the Russian ruble were determined as the exchange rates arising at the TICEX session of the previous Friday. Since August 12, 1996, the official rates are set daily. Official rates for other convertible currencies are determined on the basis of the cross rates for the U.S. dollar and the currencies concerned in the London market. For the currencies of the other BRO states, official exchange rates are determined on the basis of the official cross rates for the Russian ruble as determined in the Moscow market. Official exchange rates are used only for government transactions and accounting purposes. Compulsory sales of foreign exchange by exporters to the NBG have been abolished since January 1996.

175. On December 31,1999 , the official exchange rates were lari 1.960 per U.S. dollar and lari 0.071 per Russian ruble.

\section{Administration of control}

176. The NBG is responsible for administering exchange control regulations, which are formulated in collaboration with the Ministry of Finance. Decree No. 259, of March 5, 1992, on "The First State of Liberalization of Foreign Economic Activity" established the legal basis for the conduct of foreign economic activities in Georgia. The main provisions of this decree: (i) allow all enterprises to engage directly in foreign trade; (ii) allow all residents to acquire and hold foreign currency and engage in foreign transactions with a licensed foreign exchange dealer; and (iii) authorize banks to open foreign exchange accounts for all residents.

177. The NBG has the authority to issue general foreign exchange dealing licenses to banks to permit them to engage in foreign exchange transactions with residents and nonresidents and to open correspondent accounts with banks outside of Georgia. The NBG also has the authorities to issue internal licenses to banks which permit them to engage in the same range of foreign exchange transactions as general license holders, except that holders of internal licenses may not open correspondent accounts with banks abroad; all transfer of foreign exchange by holders of internal licenses must be carried out through correspondent accounts held either with the NBG or with a bank that holds a general license. The NBG also has the authorities to issue licenses for the establishment of exchange bureaus to engage in exchange transactions of all kinds in banknotes. 


\section{Prescription of currency}

178. Residents of Georgia may make and receive payments and transfers in any convertible currency.

\section{Resident and nonresident accounts}

179. Resident individuals and enterprises are permitted to open and operate foreign exchange accounts at banks in Georgia. The balances in these accounts may be used for all authorized transactions. The opening of foreign exchange accounts abroad by residents is subject to authorization by the Ministry of Finance and the NBG. Nonresidents may maintain foreign exchange and local currency accounts with banks in Georgia and may freely remit funds from these accounts offshore. The export of cash currency is permitted by non-residents up to a limit equal to the amount of currency originally imported; exports by non-residents of cash in excess of the amount imported by more than US $\$ 500$ but less than US\$10,000 are subject to a fee of 2 percent, beyond this amount the fee is 3 percent. The export of cash by residents is unrestricted up to an amount of US\$500. Beyond this amount, exports of cash, excluding amounts for business travel expenses, are subject to a 2 percent fee, with amounts over US\$10,000 subject to a 3 percent fee (Decree No. 1 of January 6, 1995 on Provisional Rules for the Export on Foreign Currency Notes by Citizens, as amended by Decree No. 158 of May 6, 1995).

\section{Imports and import payments}

180. The Ministry of Trade and Foreign Economic Relations regulates all foreign trade of Georgia. ${ }^{77}$ There are no quantitative restrictions on imports, and licenses are generally not required. A customs duty of 12 percent is levied on most non-CIS imports; certain goods are subject to a customs duty of 5 percent as of January 1, 1997, including specific capital goods, medical goods, electricity natural gas, and equipment previously taxed at 12 percent, and certain raw materials. Humanitarian aid, literature published by Georgian citizen abroad, diplomatic shipments, non-commercial imports for internal consumption by cultural groups or certain institutions and activities of the patriarchate, gifts valued at less than US\$3,000 and personal belongings, goods in transit and for re-export, and various categories of foods and medicines are exempt from customs duty. All imports are subject to a general customs processing fee of 0.2 percent. Foreign exchange to pay for imports may be purchased freely from authorized banks at market rates.

${ }^{77}$ Decree No. 265 on Quotas and licensing of Merchandise Trade of March 31, 1993 and Decree No. 35 of January 23, 1995, on the State Regulations of the Export and Import of Goods and Services. 


\section{Exports and export proceeds}

181. A limited range of goods are subject to export prohibitions or licensing requirements. Effective July 1, 1998, the export prohibitions on scrap metals was abolished and replaced with a specific custom duty. The export tax on scrap metal was eliminated in 1999. Licenses, are required for the export of woods in trunks and pine seeds; numismatic collections considered national treasures; certain biological (species of animals and plants), paleontological, archeological, and ethnographic goods; and raw materials for medicine production. All exports are subject to a general customs processing fee of 0.2 percent. Export contract registration requirements have been abolished as of December 1996.

\section{Payments for and proceeds from invisibles}

182. Residents may freely purchase foreign exchange to make payments for invisible transactions or use foreign exchange balances in their foreign exchange accounts with authorized banks without restriction. Proceeds from invisibles are subject to the same regulations and procedures as those applicable to the proceeds from exports. The importation of foreign currency bank notes is unrestricted, but amounts must be declared by non-residents.

\section{Capital}

183. Inward and outward capital operations are not restricted. Since July 15,1996 , the amount of cash lari that can be taken out of the country by a resident or nonresident without permission is limited to four units of each currency denomination.

\section{Gold}

184. A license is required to conduct both international and domestic trade in gold. 


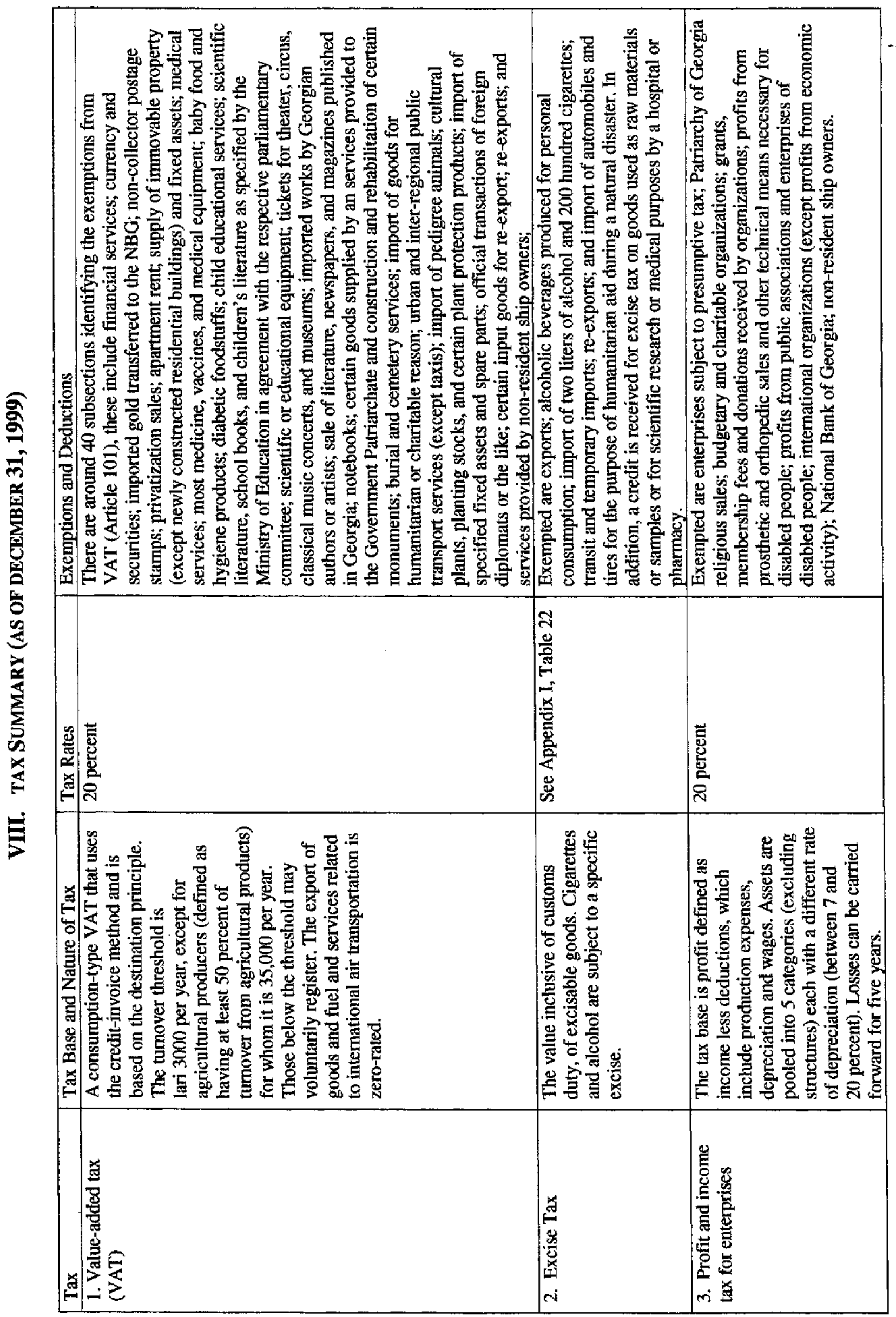




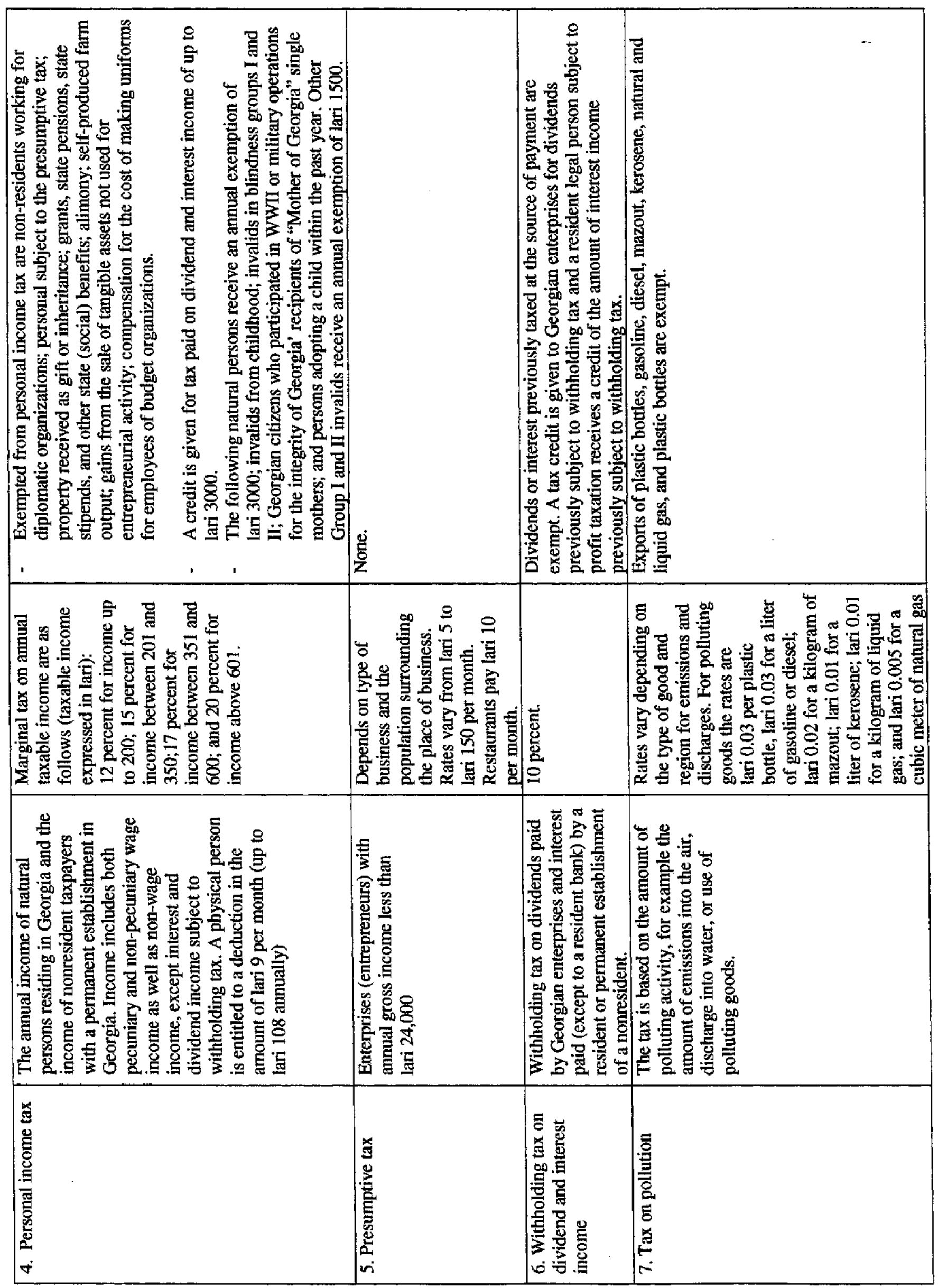




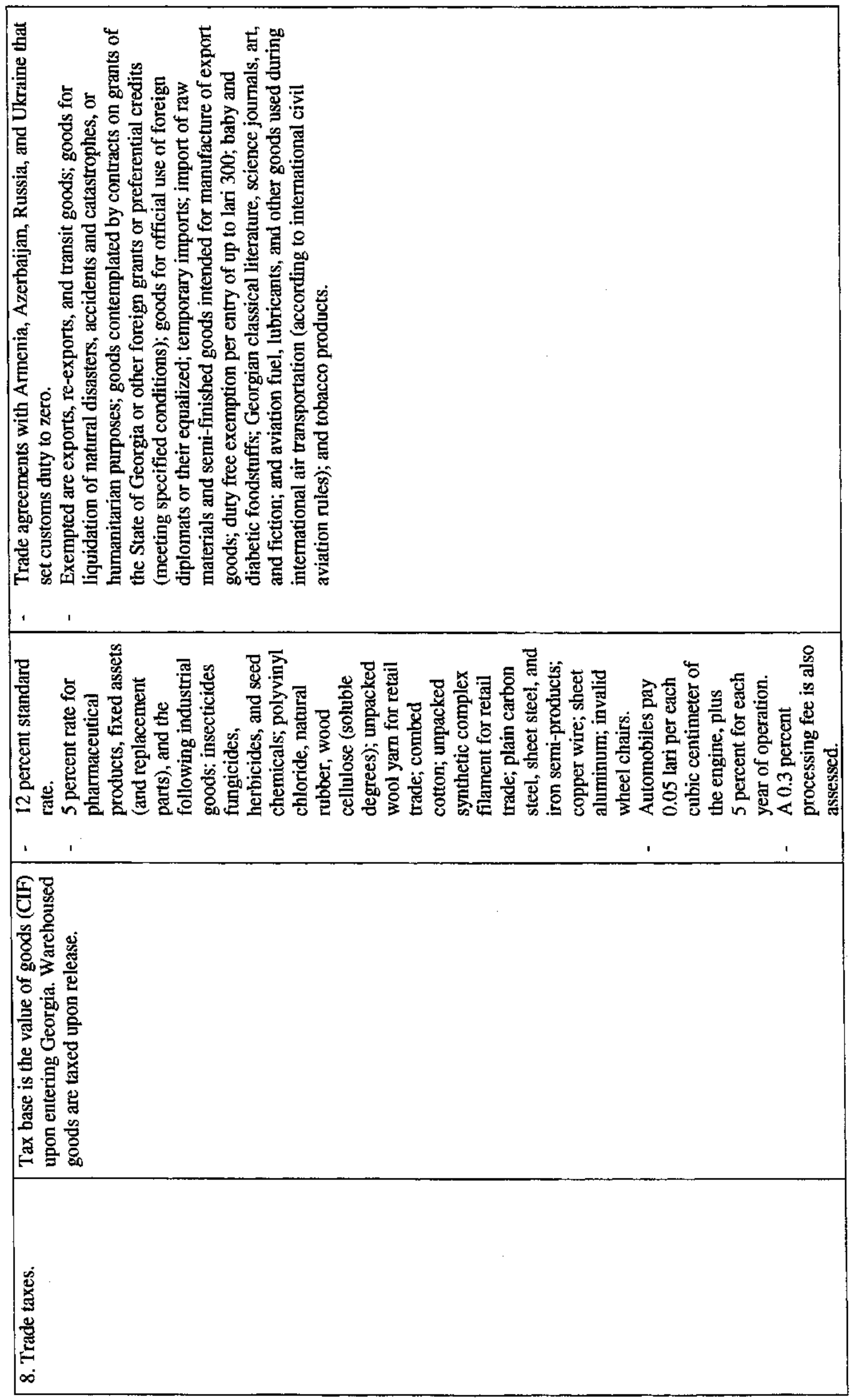




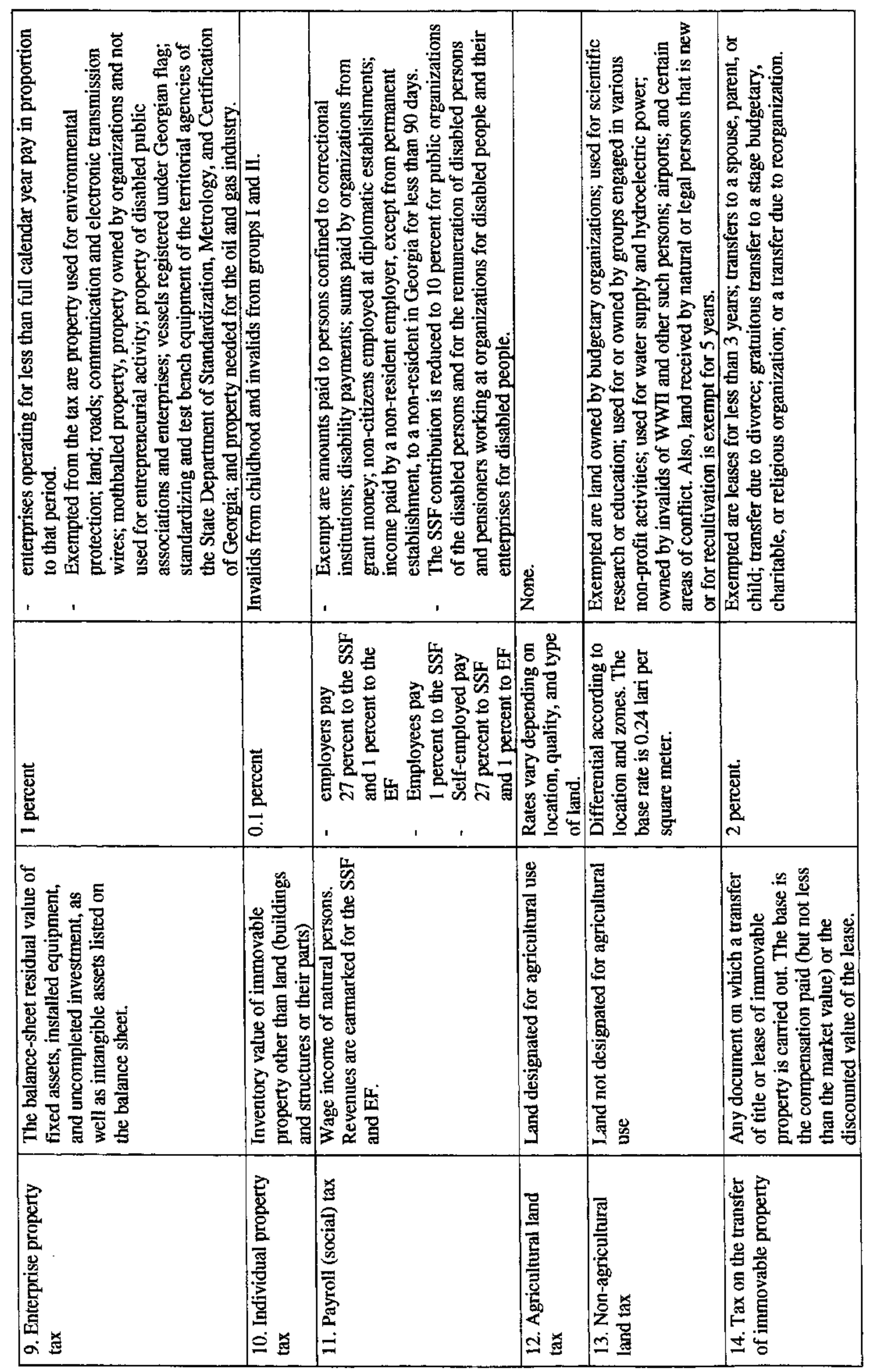




\begin{tabular}{|c|c|c|c|c|}
\hline 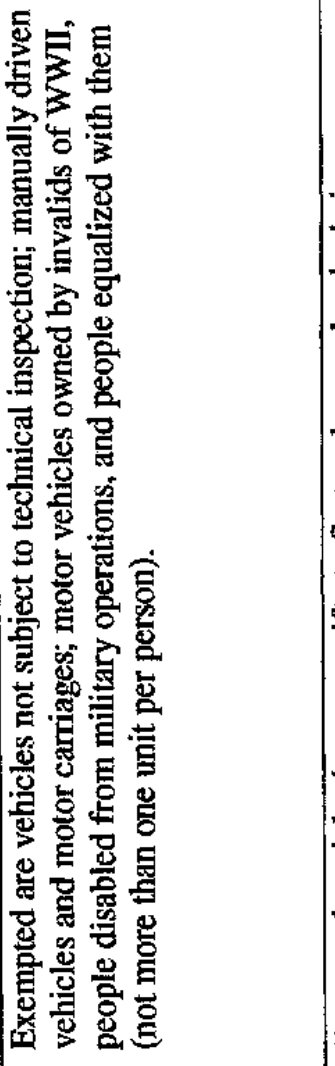 & 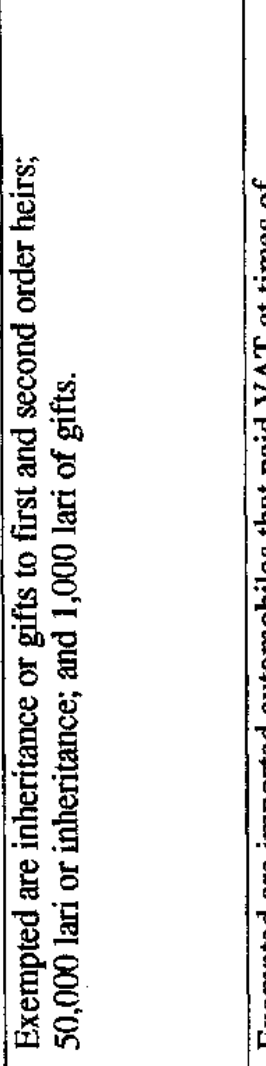 & 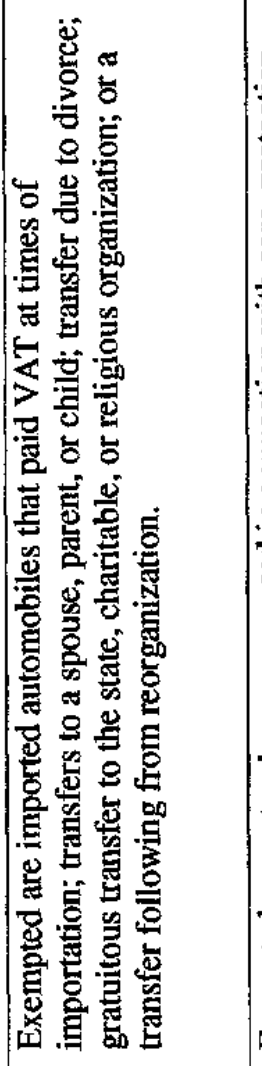 & 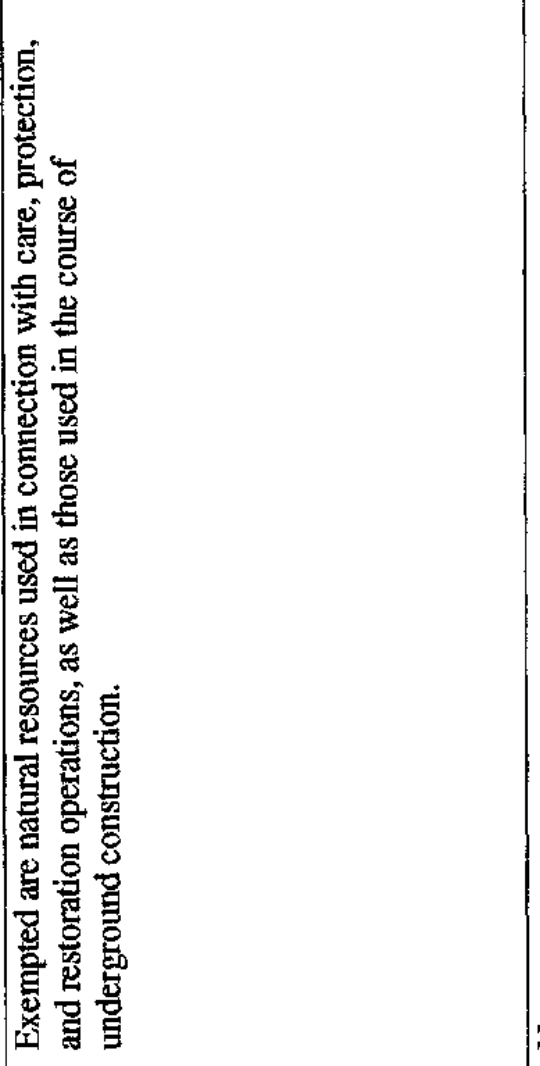 & 冚 \\
\hline 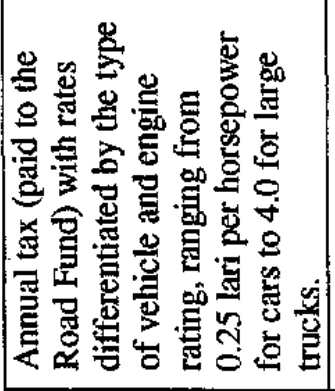 & 苞 & $\begin{array}{l}\overrightarrow{\mathrm{D}} \\
\stackrel{\mathrm{d}}{\mathrm{d}} \\
\stackrel{\mathrm{N}}{\mathrm{N}}\end{array}$ & 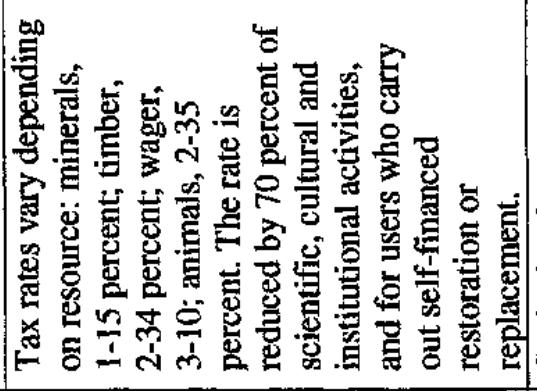 & 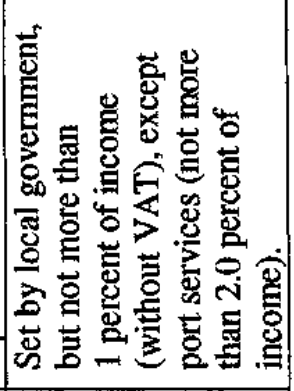 \\
\hline 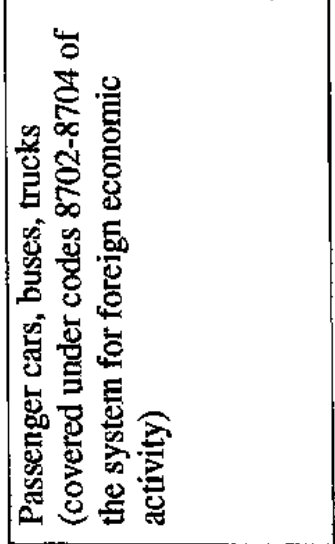 & 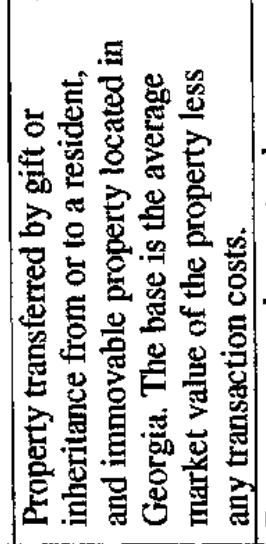 & 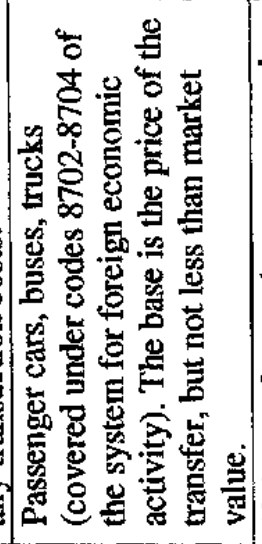 & 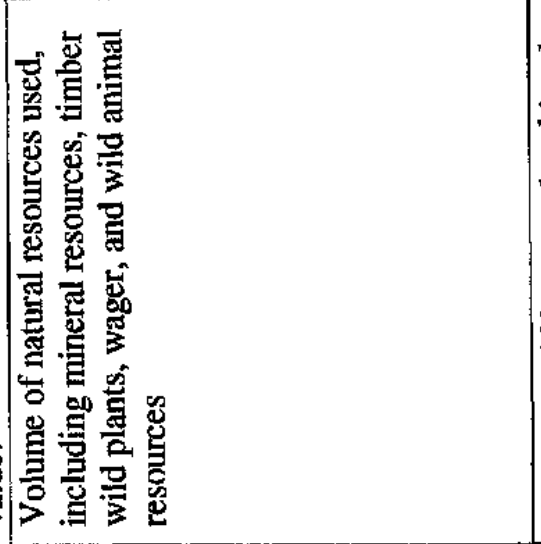 & 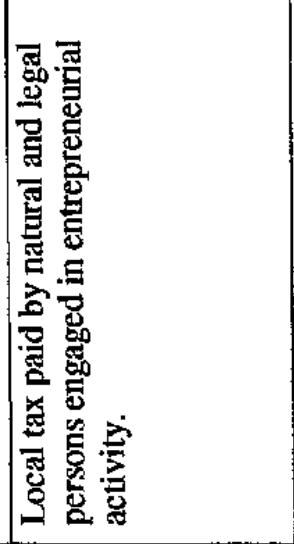 \\
\hline 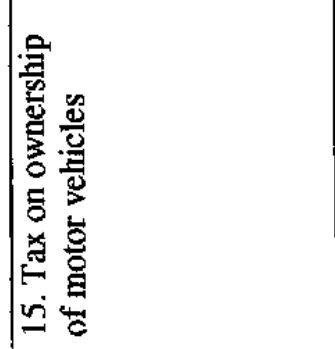 & 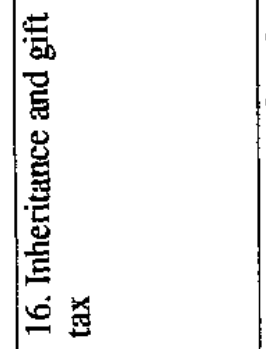 & 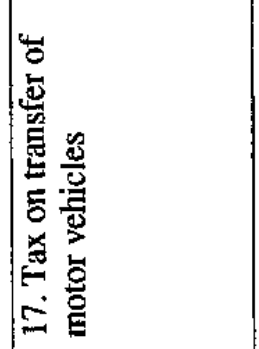 & 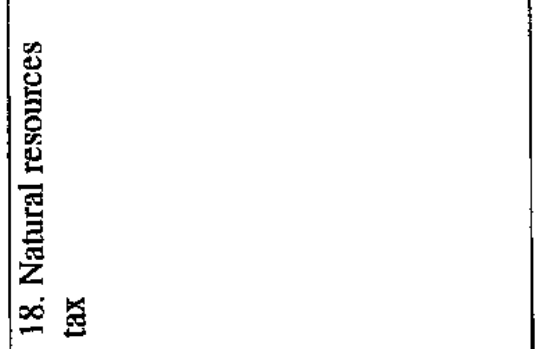 & 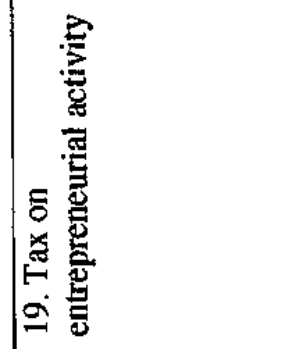 \\
\hline
\end{tabular}




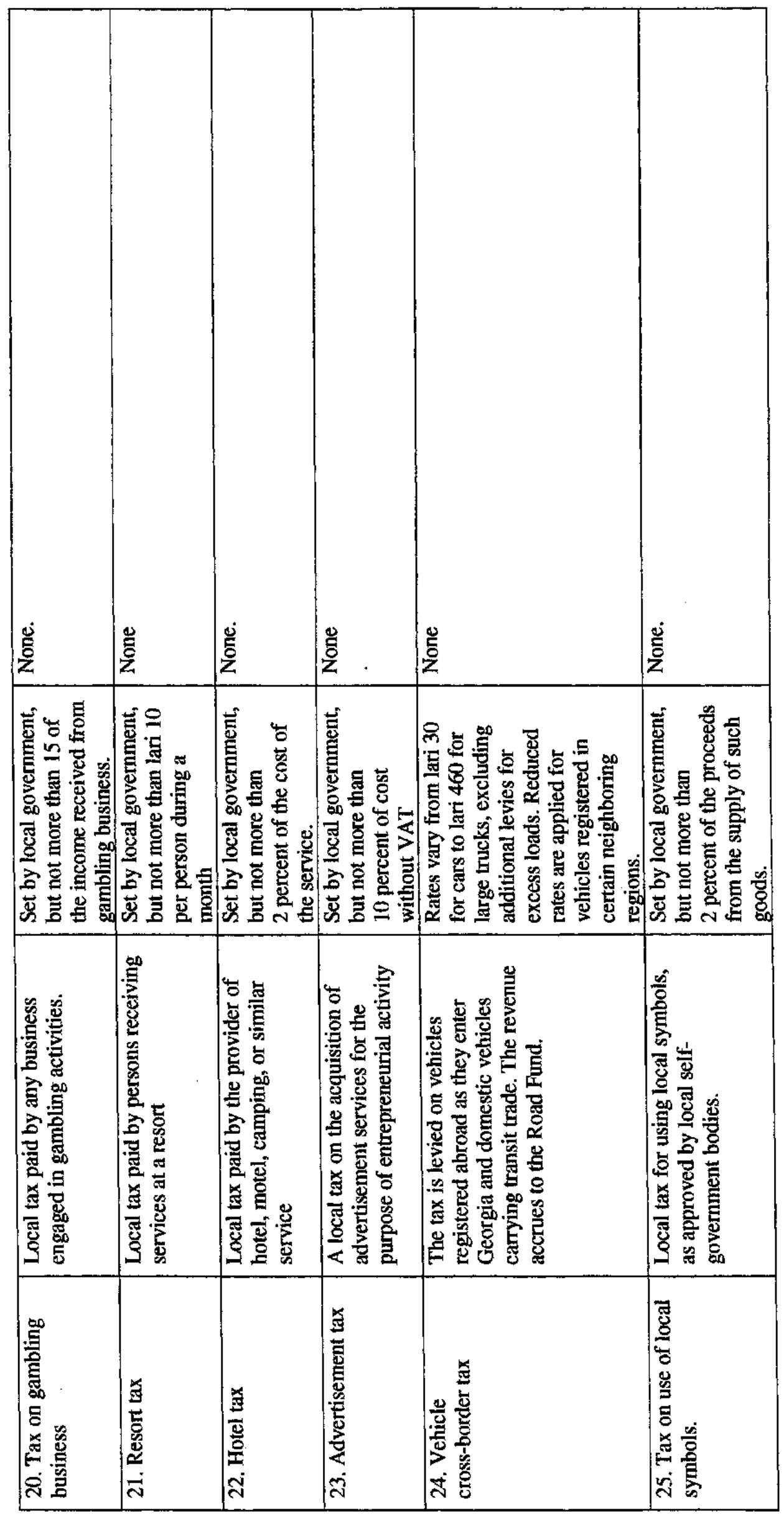




\section{AN ESTIMATE OF POTENTIAL TAX REVENUE IN GEORGIA}

1. Attempts to improve the fiscal situation in Georgia have been hampered by the inability to collect taxes. Arguably, the primary impediment to mobilizing revenue is low rates of compliance rather than low tax rates or widespread de jure tax exemptions. The purpose of this section is to quantify the amount of revenue that could be collected from the existing tax system with no changes in policy, in other words if it was administered to the fullest extent (effectively, 100 percent compliance). In short, the answer is that the current tax system should be yielding tax revenue of around 26 percent of GDP, suggesting that current tax collections are at around 53 percent of potential (Table 7). While no tax system will collect 100 percent of potential revenue, it is clear that tax revenue could increase dramatically simply by improving the administration of existing taxes. ${ }^{1}$

Table 7. Georgia: Foregone Tax Revenue, 1998-99

(In percent of GDP, unless otherwise indicated)

\begin{tabular}{lcccc}
\hline & 1998 & 1999 & 1999 & $\frac{\text { Tax Compliance Rate }}{\text { (In percent) }}$ \\
\hline Total tax revenue & & & & 53.0 \\
Taxes on income & 13.4 & 14.0 & 26.4 & 94.9 \\
Taxes on profits & 1.8 & 1.9 & 2.0 & 33.1 \\
VAT & 1.1 & 1.0 & 3.0 & 43.2 \\
Custom duties & 4.6 & 4.4 & 10.3 & 30.3 \\
Excises & 1.4 & 0.6 & 2.0 & 55.4 \\
Other taxes & 0.8 & 2.1 & 3.8 & 100.0 \\
Extrabudgetary revenue & 1.3 & 1.6 & 1.6 & 63.5 \\
SSF (excluding budgetary & 2.5 & 2.4 & 3.7 & 62.1 \\
payroll) & 1.8 & 1.7 & 2.7 & 71.7 \\
EF & & & & 67.0 \\
Road Fund & 0.1 & 0.1 & 0.1 & 41.7 \\
$\quad$ Of which: gasoline excise & 0.5 & 0.6 & 0.9 & \\
\hline
\end{tabular}

Sources: Georgian authorities; and Fund staff estimates.

2. The magnitude of the shortfall is striking, but it is important to note that Georgia has a modern tax system with tax rates that are on par with countries attaining significantly higher tax yields. For example, Georgia has a relatively broad based VAT of 20 percent, a corporate tax rate of 20 percent, a top marginal personal income tax rate of 20 percent (which commences at relatively low levels of income), excises on typically excisable goods (including of 80 percent on petroleum products), and payroll taxes of 28 percent. Even from a broad perspective, it is clear that under such a system potential tax revenue above 20 percent of GDP is by no means unreasonable.

\footnotetext{
${ }^{1}$ The large informal sector also results in a revenue loss. It is estimated that if all economic activities were in the formal, taxable sector, the tax base would increase by at least 12 percent of GDP.
} 
3. It should be noted that the analysis is complicated by the lack, in many cases, of adequate data. While this impediment is overcome by imputing or estimating the necessary data, it suggests that there is a reasonable amount of variance in the estimated parameters. It could also be questioned whether a comparative static exercise of this sort is valid to estimate such large revenue movements. Ideally, a general equilibrium model approach would be preferable. For example, to be more realistic, a private sector production and expenditure response in response to the higher taxes actually paid should be modeled. It is possible that part of the low compliance is a reflection of extremely low productivity in the private sector. Likewise, private consumption would be expected to adjust in response to a large increase in VAT payments. Nonetheless, the magnitude of the deviation between actual and potential revenue has been large, and in all likelihood the qualitative results would probably not be significantly affected by the presence of more accurate or detailed data or by applying a more comprehensive estimation methodology. However, the exact quantification of the revenue gap should be treated with an appropriate sense of variance.

4. The subsequent sections examine the results tax by tax and discuss the methodology used to estimate potential revenue for each tax.

\section{Income, profits, and payroll taxes.}

5. The potential revenue from taxation of personal income is estimated to be 2 percent of GDP, which is only 5 percent higher than current collections. This low potential reflects the large share of employment in the informal economy that minimizes the scope for increasing revenue even with substantial improvements to tax administration. The very conservative estimate of taxable income has been derived by using data on income distribution from a World Bank study on poverty for the rural and urban population, which is then scaled to the level reported in household income and expenditure surveys in 1998 . $^{2}$ This income base is then adjusted by treating as nontaxable income transfers from the state, in-kind income (as a substitute for own consumption), and unreported income (informal economic activities). The resulting estimate of taxable personal income can be regarded as the tax base the authorities ought to tax, given the tax legislation and the structure of the economy. As indicated in Table 7, the personal income tax is non-linear, but using the above average taxable income estimate of lari 55 , the average tax rate is 12 percent.

6. The potential revenue from payroll taxes, at 2.7 percent of GDP, is much greater than that for personal income taxes. Only 60 percent of potential revenue is currently being collected. The tax base for payroll taxes is essentially wage income, income from self-employment, and farm income, but the rates are significantly higher than the personal income tax. An employer or self-employed person is supposed to pay 27 percent of wage income to the Social Security Fund (SSF) and 1 percent to the Employment Fund (EF). In addition, with the exception of self-employed, the employee also pays an additional 1 percent

\footnotetext{
${ }^{2}$ See Georgia: Poverty and Income Distribution, World Bank, 1999.
} 
of wage income to the SSF. The estimated payroll tax base excludes the government wage bill (payroll taxes paid by budgetary organizations are treated as an intergovernmental transfer in the consolidated government accounts).

7. The potential revenue from profit taxes is estimated to be around 3 percent of GDP, more than three times the actual collection rate. The official national accounts data do not include data on income. But it is assumed that profits amount to 20 percent of GDP, so the tax base is therefore 20 percent of GDP. However, the base is reduced by 25 percent to allow for depreciation allowances and loss carry forwards. The remaining base is then multiplied by the flat marginal rate of 20 percent.

\section{VAT, excise, and custom duties}

8. Potential revenue from the VAT at 10.3 percent of GDP is estimated to be almost 60 percent higher than actual collections in 1999 . Due to the perceived unsatisfactory quality of consumption data, potential VAT revenue has been estimated starting from GDP and adjusting for: (i) the trade balance; (ii) capital investment; (iii) estimated value added in the exempt sectors; (iv) government expenditure on salaries and wages; (v) exempt final private expenditure; and (vi) sales by firms below the administrative threshold. The estimate suggests that each percentage point of the VAT rate might potentially yield about 0.5 percent of GDP in revenue. Given the broad-based tax base, at least on paper, with relatively few exemptions and the VAT rate of 20 percent, this is a quite credible result.

9. While excise collections have picked up significantly in 1999, revenue is still almost 45 percent below potential (estimated to be around 3.8 percent of GDP). Potential revenue is calculated by focusing on the two most important excisable goods-cigarettes and petroleum products. The consumption of cigarettes is estimated to be 375 million packs per year, a volume that should yield at the corresponding tax rates (prior to the recent increase in rates), potential cigarette excise revenue of lari 82 million. Turning to petroleum products, potential revenue is estimated from volume and price data provided by the authorities for gasoline, diesel, kerosene, and lubricants. An excise rate of 80 percent is used, even though the rate only went from 60 percent to 80 percent in July 1999. In addition, 30 percent of gasoline excise revenue is recorded as Road Fund revenue. Under these assumptions, potential excise revenue is around lari 132 million, excluding around lari 28 million in Road Fund gasoline excise revenue.

10. Potential custom duty revenue is particularly difficult to estimate given that the primary source for import data is actually the customs department. Based on 1998 reported trade data, the potential revenue is estimated to be 2.0 percent of GDP, which is two-thirds greater than actual collections. Actual 1998 collections, however, included around lari 12 million in petroleum customs duties that were subsequently rebated in 1999 , since they allegedly were collected on imports from countries that have free trade agreements with Georgia. Even though revenue in 1999 is understated by the amount of rebates, the significant depreciation of the lari in the latter part of 1998 should have lead to an increase in the lari value of imports in 1999_-despite an estimated decline in volume - suggesting that 
potential revenue in 1999 would have been higher than in 1998. The potential revenue is calculated by taking the value of imports, less the 42 percent that come from countries that have free trade agreements with Georgia, and then less another 5 percent for the assumed amount of exempt goods. Of the remaining tax base, it is assumed that 25 percent is subject to the 5 percent rate and the remainder to the more prevalent 12 percent rate.

\section{Other taxes and Road Fund}

11. Due to the paucity of data, it is assumed that other taxes and Road Fund non-excise revenue are already at potential revenue. This is done not only for simplicity, but also to keep with the spirit of making this a somewhat conservative estimate of potential revenue. In the case of other taxes, which comprise various local taxes, this assumption is clearly not correct. The land tax and the environmental tax, which includes a specific tax on some petroleum products, are in all likelihood performing well below potential. For the Road Fund, it is difficult to determine how much revenue could be generated from their own source. 
Table 8. Georgia: GDP by Origin, 1996-99

\begin{tabular}{|c|c|c|c|c|}
\hline & 1996 & 1997 & 1998 & 1999 \\
\hline \multirow{3}{*}{ Nominal GDP } & \multicolumn{4}{|c|}{ (In millions of lari) } \\
\hline & 3,768 & 4,505 & 4,795 & 5,594 \\
\hline & \multicolumn{4}{|c|}{ (In percent of GDP) } \\
\hline Agriculture, ljvestock and agro-industry & 39.1 & 34.5 & 31.6 & 33.2 \\
\hline Industry & 14.9 & 13.6 & 13.0 & 13.0 \\
\hline Construction & 2.7 & 3.6 & 4.4 & 3.8 \\
\hline Transport and communications & 5.7 & 7.8 & 11.2 & 11.6 \\
\hline Trade & 12.4 & 11.2 & 10.9 & 11.7 \\
\hline Financial intermediation & 0.7 & 1.0 & 1.3 & 1.3 \\
\hline Health and education & 3.6 & 4.2 & 4.3 & 3.6 \\
\hline Real estate and rent & 10.4 & 9.5 & 9.2 & 8.2 \\
\hline Net taxes & 3.0 & 6.0 & 5.0 & 5.3 \\
\hline \multirow[t]{2}{*}{ Other } & 7.6 & 8.8 & 9.1 & 8.4 \\
\hline & \multicolumn{4}{|c|}{ (Percent change) } \\
\hline Real GDP & 10.5 & 10.8 & 2.9 & 3.0 \\
\hline
\end{tabular}

Source: Georgian State Department of Statistics. 
Table 9. Georgia: Production of Selected Industrial Commodities, 1995-98 1/ (In thousands of tons; unless otherwise indicated)

\begin{tabular}{|c|c|c|c|c|}
\hline & 1995 & 1996 & 1997 & 1998 \\
\hline \multicolumn{5}{|l|}{ Fuel and energy } \\
\hline Electric power (in billions of $\mathrm{kWh}$ ) & 7.1 & 7.2 & 7.2 & 8.1 \\
\hline Coal & 42.6 & 22.5 & 4.6 & 14.7 \\
\hline Oil & 42.7 & 128.0 & 134.0 & 119.2 \\
\hline Natural gas (in millions of $m 3$ ) & 3.3 & 3.3 & $\ldots$ & $\ldots$ \\
\hline Gasolìne & 6.7 & $\ldots$ & 4.4 & 2.4 \\
\hline Diesel fuel & 10.8 & 4.5 & 8.1 & 4.7 \\
\hline \multicolumn{5}{|l|}{ Metallurgy } \\
\hline Steel & $8 B .4$ & 82.7 & 103.0 & 56.4 \\
\hline Finished roll steel & 70.2 & 58.6 & 86.7 & 42.8 \\
\hline Rolled ferrous metal & 74.5 & 67.2 & 93.2 & 42.8 \\
\hline Steel pipes & 37.8 & 34.0 & 23.5 & 8.8 \\
\hline Manganese ore & 41.9 & 101.9 & 14.2 & 16.0 \\
\hline \multicolumn{5}{|l|}{ Machine-building } \\
\hline AV motors (in thousands of $\mathrm{kW}$ ) & 1.1 & 1.2 & 0.0 & $\cdots$ \\
\hline Machine tools (in units) & 57.0 & 18.0 & 28.0 & 21.0 \\
\hline Flooding electric engines (in thousands of units) & 0.7 & 0.4 & 0.3 & 0.1 \\
\hline Lifting motors (in thousands of units) & 1.8 & 0.7 & 0.6 & 0.2 \\
\hline \multicolumn{5}{|l|}{ Chemical/timber products } \\
\hline Mineral fertilizers $2 f$ & 42.7 & 68.0 & 80.9 & 55.4 \\
\hline Synthetic anmoniac & 65.6 & 93.2 & 102.1 & 77.5 \\
\hline Sawdust (in thousands of $\mathrm{m} 3$ ) & 15.3 & 15.4 & 17.0 & 31.0 \\
\hline \multicolumn{5}{|l|}{ Construction } \\
\hline Prefabricated ferro-concrete structures (thousands of $\mathrm{m} 3$ ) & 11.1 & 9.6 & 8.3 & 8.3 \\
\hline Building bricks (in millions of units) & 6.8 & 9.4 & 11.7 & 13.1 \\
\hline \multicolumn{5}{|l|}{ Light industry } \\
\hline Silk thread (ir tons) & 42.6 & 17.6 & 8.6 & $\ldots$ \\
\hline Cotton yam & 0.6 & 0.4 & 0.1 & 0.1 \\
\hline Wool yarn & 0.3 & 0.2 & 0.1 & 0.0 \\
\hline Fabrics, total (in millions of cubic square) & 2.2 & 1.3 & 0.5 & 0.2 \\
\hline \multicolumn{5}{|l|}{ Basic foodstuff and food-processing } \\
\hline Granulated sugar & 0.2 & 25.8 & 19.7 & $\ldots$ \\
\hline Meat products & 0.3 & 0.5 & 1.0 & 1.4 \\
\hline Fish and fish products & 0.5 & 0.6 & 1.4 & 0.0 \\
\hline Dairy products & 4.8 & 4.4 & 6.4 & 6.7 \\
\hline Canned food & 8.7 & 7.9 & 9.0 & 1.9 \\
\hline Tea, primary processed & 8.0 & 8.9 & 9.2 & 10.2 \\
\hline Natural tea & 4.2 & 3.7 & 5.6 & 5.2 \\
\hline Macaroni products & 4.3 & 0.5 & 0.3 & 0.8 \\
\hline Non-alcobolic beverages (in millions of decaliters) & 0.6 & 1.6 & 4.0 & 2.9 \\
\hline Mineral water (in millions of $1 / 2$ liters) & 9.4 & 36.1 & 66.4 & 58.2 \\
\hline Cigarettes (in biltions) & 1.8 & 1.2 & 0.9 & 0.6 \\
\hline Vodka and liqueurs (in thousands of decaliters) & 102.6 & 132.0 & 247.0 & 309.8 \\
\hline Grape wine (in thousands of decaliters) & $3,670.0$ & $2,283.0$ & $2,458.0$ & $2,179.0$ \\
\hline Champagne (in thousands of decaliters) & 49.2 & 94.6 & 137.0 & 51.9 \\
\hline Cognac (in thousands of decaliters) & 157.9 & 135.0 & 74.0 & 47.6 \\
\hline Beer (in thousands of decaliters) & 652.9 & 476.0 & 785.0 & 740.0 \\
\hline
\end{tabular}

Sources: Georgian authorities; and Fund staff estimates.

1) Data for Abkhazia and South Ossetia are not included. 
Table 10. Georgia: Transportation Indicators, 1995-99

(In thousands of tons)

\begin{tabular}{lrrrrr}
\hline & 1995 & 1996 & 1997 & 1998 & $19991 /$ \\
\hline & & & & & \\
Freight transport & 14,983 & 14,146 & 19,696 & 24,000 & 15,774 \\
Rait & 4,656 & 4,784 & 7,231 & 8,400 & 5,355 \\
Road & 8,690 & 8,800 & 12,200 & 15,000 & 10,000 \\
Sea & 1,637 & 562 & 265 & 600 & 419 \\
\hline
\end{tabular}

Source: Georgian State Department of Statistics.

1/ January-August. 
Table 11. Georgia: Population and Employment, 1995-98

(In thousands)

\begin{tabular}{|c|c|c|c|c|}
\hline & 1995 & 1996 & 1997 & $19985 /$ \\
\hline Total population $1 /$ & $5,374.3$ & $5,377.2$ & $5,388.0$ & $5,398.5$ \\
\hline Males & $2,562.9$ & $2,565.5$ & $2,572.7$ & $2,580.0$ \\
\hline Fernales & $2,811.4$ & $2,811.7$ & $2,815.3$ & $2,818.5$ \\
\hline Urban & $2,369.2$ & $2,969.0$ & $2,975.4$ & $2,984.1$ \\
\hline Rural & $2,405.1$ & $2,408.2$ & $2,312.6$ & $2,414.4$ \\
\hline Under 16 years of age & $1,313.2$ & $1,281.2$ & $1,247.5$ & $1,210.4$ \\
\hline In active years 2 & $2,988.8$ & $2,990.8$ & $3,308.8$ & $3,323.2$ \\
\hline Over active age & $1,072.3$ & $1,105.2$ & 831.7 & 864.9 \\
\hline Population employed $3 /$ & $1,730.0$ & $2,036.2$ & $2,233.2$ & $1,886.4$ \\
\hline State sector & 985.3 & 580.0 & 570.7 & 515.1 \\
\hline \multicolumn{5}{|l|}{ Of which: } \\
\hline Industry and construction & 251.7 & 138.8 & 97.7 & 80.3 \\
\hline Agriculture & 90.0 & 42.2 & 42.3 & 24.8 \\
\hline Transportation and cormmunications & 78.1 & 68.6 & 58.4 & 59.5 \\
\hline Trade and other materials sectors & 41.1 & 39.2 & 31.3 & 29.4 \\
\hline Health, education, and science & 211.1 & 215.5 & 240.2 & 226.7 \\
\hline Administration and finance & 44.1 & 35.3 & 45.3 & 40.1 \\
\hline Other nonmaterial sector & 76.4 & 40.4 & 55.5 & 54.3 \\
\hline Cooperatives $4 /$ & 110.7 & 55.4 & 47.0 & 31.6 \\
\hline Lndustry and construction & 40.1 & 27.4 & 23.4 & 22.7 \\
\hline Agriculture & 40.3 & 24.4 & 22.0 & 8.9 \\
\hline Other & 30.3 & 3.6 & 1.6 & $\ldots$ \\
\hline Private sector & 634.0 & $1,400.7$ & $1,615.5$ & $1,371.3$ \\
\hline \multicolumn{5}{|l|}{ Of which: } \\
\hline Self-employed & 6.4 & $1,324.4$ & $1,529.2$ & $1,297.2$ \\
\hline Retired (receiving pension) & $1,140.7$ & $1,104.7$ & $1,022.0$ & $\ldots$ \\
\hline \multicolumn{5}{|l|}{ Of which: } \\
\hline Retirees employed & 65.2 & 65.1 & 64.7 & $\ldots$ \\
\hline
\end{tabular}

Source: Georgian State Department of Statistics.

1/ Total population may be significantly overestimated because data include persons registered in Georgia but living abroad.

2/ Since February 20, 1996, working age is 16.60 for women, and 16-65 years for men. Prior to that date, working age was $16-55$ for women, and 16-60 years for men.

3/ Excludes employment in the informal sector. Official estimates indicate that, as of end-1997 employment on the informal sector was about 750,000 persons.

4/ Including collective farms and consumer cooperatives.

5/ 1998 data is an estimate; first part of the data is not available at this point. Since 1998 State Department of Statistics has started the implementation of Labor force surveys (using the ILO methodology). The data obtained through these surveys are under revision and will be available in near future. 
Table 12. Georgia: Unemployment, 1995-99

(Number of persons, end-of-period)

\begin{tabular}{lccccc}
\hline & 1995 & 1996 & 1997 & 1998 & $19991 /$ \\
\hline $\begin{array}{c}\text { Registered unemployed } \\
\begin{array}{c}\text { Of which: } \\
\text { Receiving benefits }\end{array}\end{array}$ & 65,450 & 53,372 & 142,795 & 98,512 & 99,155 \\
\hline
\end{tabular}

Sources: Ministry of Labor and Social Affairs; and Georgian State Department of Statistics.

1/ As of September 1, 1999. 


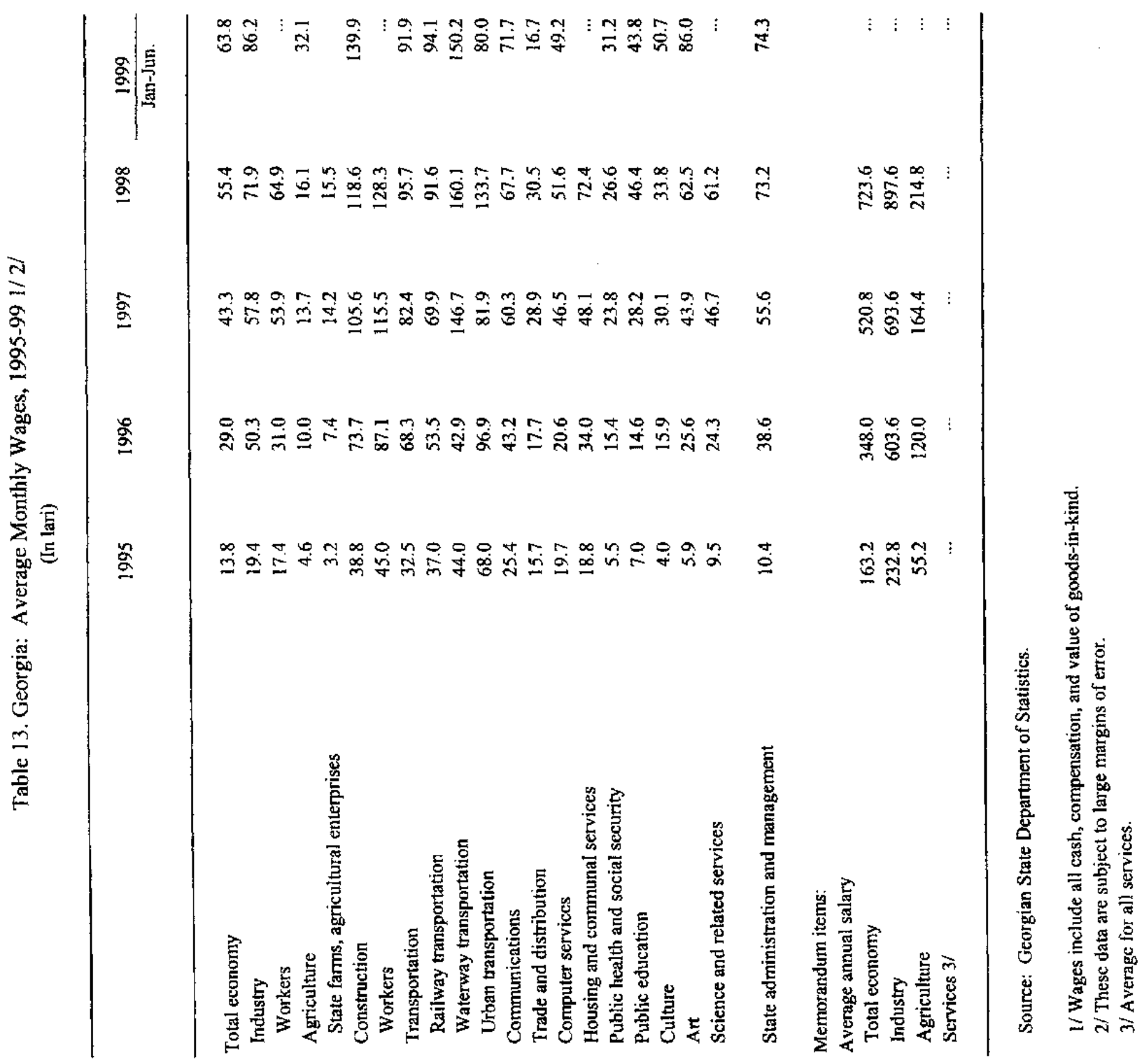


$-91-$

Table 14. Georgia: Government Wages and Pensions, 1995-99 V/

\begin{tabular}{|c|c|c|c|c|c|c|}
\hline & \multicolumn{2}{|c|}{ Minimum monthly wage } & \multicolumn{2}{|c|}{ Average monthly wage } & \multicolumn{2}{|c|}{ Monthly pension } \\
\hline & $\begin{array}{l}\text { Nominal } \\
\text { (In lari) }\end{array}$ & $\begin{array}{c}\text { Real } 2 / \\
\text { (Jan. 1991=100) }\end{array}$ & $\begin{array}{l}\text { Nomina] } \\
\text { (In lari) }\end{array}$ & $\begin{array}{c}\text { Real 2/ } \\
\text { (Sep. 1994-100) }\end{array}$ & $\begin{array}{l}\text { Nominal } \\
\text { (In lari) }\end{array}$ & $\begin{array}{c}\text { Reai } 2 / \\
\text { (Jan. } 1991=100)\end{array}$ \\
\hline \multicolumn{7}{|l|}{1995} \\
\hline January & 1.5 & 11.3 & 7.8 & 224.4 & 3.0 & 22.5 \\
\hline February & 1.5 & 112 & 7.8 & 222.6 & 3.0 & 22.4 \\
\hline March & 1.5 & 11.5 & 7.8 & 229.5 & 3.0 & 23.1 \\
\hline April & 1.5 & 11.6 & 7.8 & 231.8 & 3.0 & 23.3 \\
\hline May & 1.5 & 11.1 & 7.8 & 220.6 & 3.0 & 22.2 \\
\hline Jure & 1.5 & 11.2 & 7.8 & 223.3 & 3.0 & 22.4 \\
\hline July & 3.5 & 259 & 9.7 & 275.2 & 3.7 & 27.4 \\
\hline August & 3.5 & 25.1 & 9.7 & 266.4 & 3.7 & 26.5 \\
\hline Septernber & 3.5 & 24.1 & 9.7 & 255.9 & 3.7 & 25.5 \\
\hline October & 3.5 & 19.5 & 10.5 & 224.5 & 3.7 & 20.7 \\
\hline November & 6.0 & 33.5 & 15.7 & 335.4 & 6,0 & 33.5 \\
\hline December & 6.0 & 32.4 & 15.7 & 324.3 & 6.0 & 32.4 \\
\hline \multicolumn{7}{|l|}{1996} \\
\hline January & 6.0 & 31.6 & 15.7 & 316.1 & 6.0 & 31.6 \\
\hline February & 7.0 & 35.5 & 17.2 & 334.3 & 7.0 & 35.5 \\
\hline March & 7.0 & 34.5 & 17.2 & 324.9 & 7.0 & 34.5 \\
\hline April & 7.0 & 34.1 & 17.2 & 321.0 & 7.0 & 34.1 \\
\hline May & 7.0 & 34.0 & 17.2 & 319.7 & 7.0 & 34.0 \\
\hline June & 9.0 & 43.4 & 23.1 & 425.4 & 8.5 & 40.9 \\
\hline July & 9.0 & 44.0 & 23.1 & 431.5 & 8.5 & 41.5 \\
\hline August & 9.0 & 44.0 & 23.1 & 431.4 & 8.5 & 41.5 \\
\hline September & 9.0 & 43.7 & 29.7 & 552.5 & 8.5 & 41.3 \\
\hline October & 9.0 & 43.6 & 29.7 & 550.3 & 8.5 & 41.1 \\
\hline November & 9.0 & 43.1 & 29.7 & 544.5 & 8.5 & 40.7 \\
\hline December & 9.0 & 42.7 & 29.7 & 539.6 & 8.5 & 40.3 \\
\hline \multicolumn{7}{|l|}{1997} \\
\hline January & 12.0 & 56.5 & 34.1 & 614.6 & 9.8 & 46.1 \\
\hline February & 12.0 & 55.3 & 34.1 & 6012.0 & 9.8 & 45.2 \\
\hline March & 12.0 & 55.0 & 34.1 & 597.8 & 9.8 & 44.9 \\
\hline April & 12.0 & 54.8 & 34.1 & 596.0 & 9.8 & 44.7 \\
\hline May & 12.0 & 54.2 & 34.1 & 589.9 & 9.8 & 44.3 \\
\hline June & 12.0 & 59.3 & 34.1 & 601.4 & 9.8 & 45.1 \\
\hline July & 12.0 & 55.8 & 34.1 & 606.9 & 9.8 & 45.6 \\
\hline August & 15.0 & 69.7 & 37.5 & 666.9 & 11.8 & 54.8 \\
\hline September & 15.0 & 68.9 & 37.5 & 659.6 & 11.8 & 54.2 \\
\hline October & 15.0 & 68.4 & 37.5 & 654.3 & 11.8 & 53.8 \\
\hline November & 15.0 & 66.8 & 37.5 & 639.4 & 11.8 & 52.6 \\
\hline December & 15.0 & 66.4 & 37.5 & 635.0 & 11.8 & 52.2 \\
\hline \multicolumn{7}{|l|}{1998} \\
\hline January & 17.0 & 75.0 & 41.3 & 696.4 & 130 & 57.3 \\
\hline February & 17.0 & 74.2 & 413 & 6890 & 130 & 56.7 \\
\hline March & 17.0 & 74.1 & 41.3 & 688.7 & 130 & 56.7 \\
\hline Aprit & 17.0 & 73.5 & 41.3 & 682.3 & 13.0 & 56.2 \\
\hline May & 17.0 & 74.7 & 41.3 & 693.8 & 13.0 & 57.1 \\
\hline June & 17.0 & 76.2 & 41.3 & 707.4 & 13.0 & 58.2 \\
\hline July & 18.7 & 85.8 & 45.4 & 797.4 & 13.0 & 59.7 \\
\hline August & 18.7 & 85.6 & 45.4 & 795.3 & 13.0 & 59.5 \\
\hline September & 18.7 & 85.5 & 45.4 & 794.3 & 13.0 & 59.4 \\
\hline October & 18.7 & 84.7 & 45.4 & 786.8 & 13.0 & 58.9 \\
\hline November & 18.7 & 83.8 & 45.4 & 778.5 & 14.0 & 62.7 \\
\hline December & 18.7 & 748 & 45.4 & 694.5 & 14.0 & 56.0 \\
\hline \multicolumn{7}{|l|}{1999} \\
\hline January & 18.7 & 72.9 & & & 14.0 & 54.6 \\
\hline February & 18.7 & 69.4 & & & 14.0 & $\$ 2.0$ \\
\hline March & 18.7 & 68.1 & 58.7 & 842.0 & 14.0 & 51.0 \\
\hline ApriI & 18.7 & 67.3 & & & 14.0 & 50.4 \\
\hline May & 18.7 & 68.4 & & & 14.0 & 51.2 \\
\hline June & 20.0 & 74.2 & 68.6 & 959.4 & 14.0 & 51.9 \\
\hline July & 20.0 & 75.8 & & & 14.0 & 53.1 \\
\hline August & 20.0 & 75.8 & & & 14.0 & 53.1 \\
\hline September 4 & 200 & 75.1 & 73.0 & 1055.8 & 14.0 & 52.6 \\
\hline October & $\ldots$ & $\ldots$ & & & ... & $\ldots$ \\
\hline November & $\ldots$ & $\ldots$ & & & $\ldots$ & $\ldots$ \\
\hline Decernber & $\ldots$ & $\ldots$ & $\cdots$ & & $\ldots$ & .. \\
\hline
\end{tabular}

Source: Georgian State Department of Statistics

If Includes only wages of budgetary organizations. 2/ CP] deflated.

3/ As of 1999, wages are reported quarterly.

4i Preliminary estimate. 
Table 15. Georgia: Consumer Price Index, 1996-99 1/2/

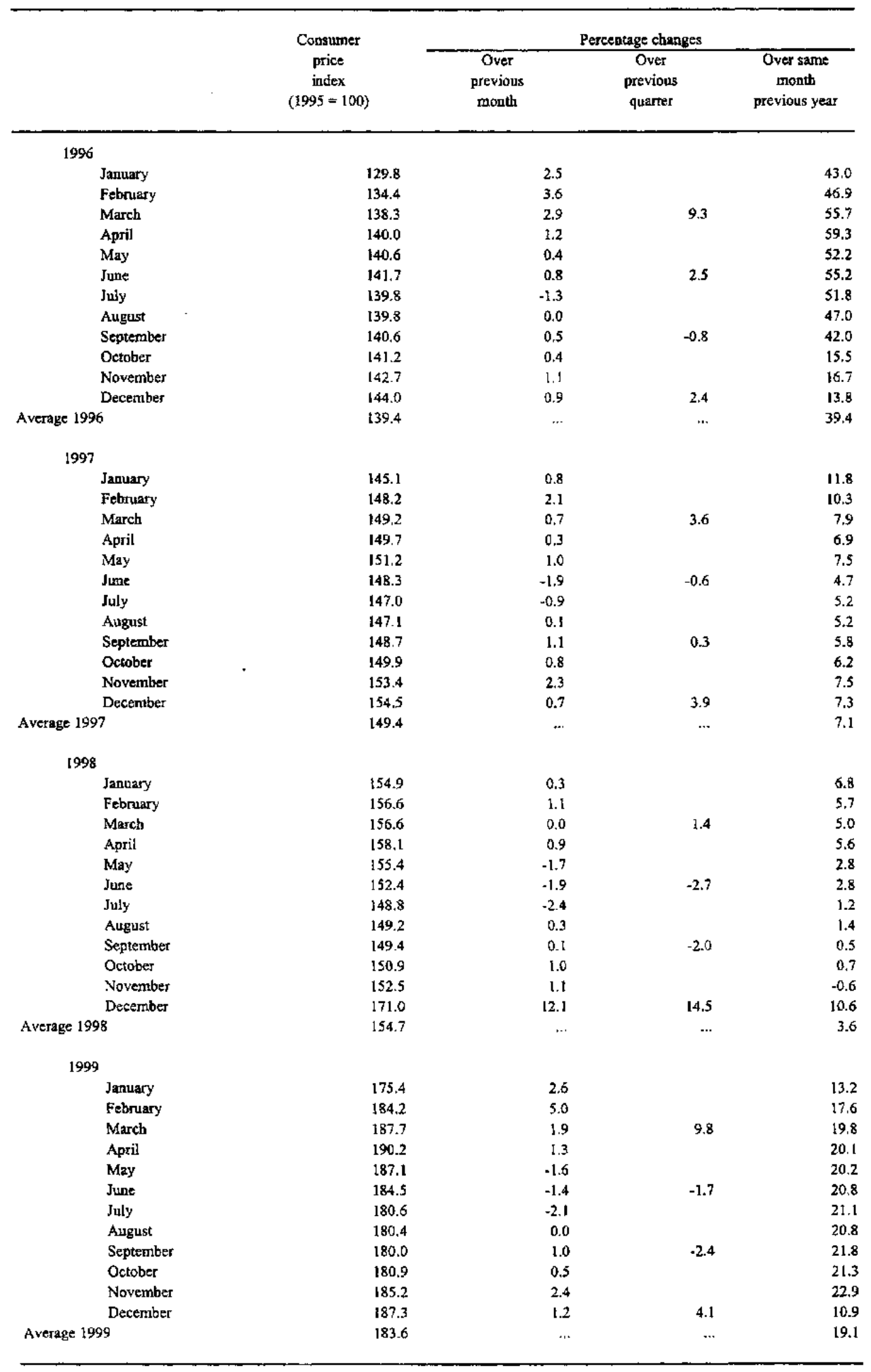

Source: Georgian State Department of Statistics.

$1 /$ According to 296-good Laspeyres index. The last revision of the CPJ weights was made in December 1997.

21 A nationat consumer price index (CPI) was introduced in january 1996. Developments in the national CPI have been very similar to the developments in the Tbilisi CPl. 
Table 16. Georgia: Sunmary of General Government Operations, 1996-99

\begin{tabular}{|c|c|c|c|c|c|}
\hline & 1995 & 1996 & 1997 & 1998 & $\begin{array}{c}1999 \\
\text { Estimated } \\
\text { outum }\end{array}$ \\
\hline & \multicolumn{5}{|c|}{ (In millions of lati) } \\
\hline Total revenue and grants (excluding privatization) & 259.0 & 530.7 & 668.8 & 786.4 & 872.7 \\
\hline Total revenue & 188.0 & 459.6 & 653.5 & 740.8 & 824.4 \\
\hline Tax revenue (exciuding extrabudgetary) & 132.8 & 317.9 & 484.6 & 526.1 & 649.2 \\
\hline Taxes on income & 20.9 & 44.5 & 76.9 & 87.8 & 104.8 \\
\hline Taxes on profits & 28.6 & 37.9 & 38.8 & 50.5 & 55.6 \\
\hline VAT & 58.5 & 133.8 & 205.5 & 219.7 & 248.3 \\
\hline Custom duties & 4.5 & 19.9 & 61.2 & 67.0 & 33.8 \\
\hline Excises & 2.8 & 25.9 & 52.7 & 38.7 & 118.2 \\
\hline Other taxes & 17.5 & 55.9 & 49.5 & 62.3 & 88.6 \\
\hline Nontax revenue & 16.9 & 50.0 & 66.3 & 97.1 & 43.0 \\
\hline Extrabudgetary revenue 1/ & 38.3 & 91.7 & 102.5 & 117.5 & 132.2 \\
\hline Grants & 71.0 & 71.1 & 15.4 & 45.7 & 48.2 \\
\hline Total expenditure and net lending & 455.5 & 809.8 & 982.4 & $1,096.4$ & $1,249.6$ \\
\hline Currest expenditure 2 & 389.4 & 736.7 & 890.5 & 997.3 & $1,151.1$ \\
\hline Wages and salaries & 59.5 & 103.7 & 155.5 & 176.7 & 191.6 \\
\hline Goods and services 31 & 116.2 & 303.9 & 274.0 & 202.4 & 188.5 \\
\hline Transfers and subsidies & 39.1 & 59.0 & 103.4 & 119.3 & 162.7 \\
\hline Interest pryments & 54.6 & 57.6 & 85.1 & 114.8 & 158,4 \\
\hline Domestic & 1.0 & 11.7 & 38.0 & 62.8 & 80.5 \\
\hline External & 53.6 & 45.9 & 47.1 & 51.9 & 77.9 \\
\hline Extrabudgetary expenditures 4 & 49.9 & 103.8 & 168.4 & 212.5 & 211.7 \\
\hline Local govemment expenditures & 70.1 & 108.7 & 104,2 & 171.7 & 238.2 \\
\hline Capital expenditure & 38.8 & 68.9 & 73.4 & 65.5 & 49.3 \\
\hline Of whitch: Foreign financed & & $\ldots$ & 17.6 & 33.5 & 43.7 \\
\hline Net lending & 27.3 & 4.2 & 18.5 & 33.6 & 49.2 \\
\hline Of which: Foreign financed & & $\ldots$ & 13.4 & 33.5 & 39.7 \\
\hline Budget contingensy & 0.0 & 0.0 & 0.0 & 0.0 & 0.0 \\
\hline Ovetall balance (commitments) & -196.5 & -279.1 & -313.6 & -309.9 & -376.9 \\
\hline Adjustment to cash basis & 26.0 & 7.9 & 28.4 & 64.0 & 101.2 \\
\hline Net change in expenditure arrears (-, reduction) & 26.8 & 7.9 & 28.4 & 64.0 & 101.2 \\
\hline External interest & 12.0 & -5.1 & -9.6 & .5 .5 & 0.0 \\
\hline Domestic expenditure & 14.8 & 13.0 & 38.0 & 69.5 & 101.2 \\
\hline Net other cash balancing & -0.8 & 0.0 & 0.0 & 0.0 & 0.0 \\
\hline Overall balance (cash) & -170.5 & -271.2 & -285.2 & -246.0 & -275.7 \\
\hline Total financing & 1705 & 271.2 & 285.2 & 246.0 & 275.7 \\
\hline Privatization & 2.9 & 19.5 & 25.7 & 73.4 & 52.7 \\
\hline Domestic & 59.4 & 156.8 & 161.6 & 97.9 & 124.2 \\
\hline NBG & $\ldots$ & $\ldots$ & $\ldots$ & 109.8 & 187.1 \\
\hline Of which: NBG recapitalization & & $\ldots$ & $\ldots$ & 0.0 & 70.3 \\
\hline Commercial banks & $\ldots$ & $\ldots$ & $\ldots$ & -9.7 & -0.6 \\
\hline Nonbank & $\ldots$ & $\ldots$ & $\ldots$ & -2.1 & 8.0 \\
\hline Offset to NBG Recapitalization & & $\ldots$ & $\ldots$ & 0.0 & -70.3 \\
\hline External & 108.2 & 94.9 & 97.9 & 74.7 & 68.8 \\
\hline Disbursements & 108.2 & 94.9 & 111.2 & 100.2 & 138.5 \\
\hline Amortization & .116 .5 & -15.5 & -69.8 & -115.4 & -183.0 \\
\hline Changes in arrears (*, reduction) & $\$ 16.5$ & 15.5 & 56.5 & -73.6 & 113.3 \\
\hline Macroecononic support & 0.0 & 0.0 & 0.0 & 163.5 & 0.0 \\
\hline Net US in-kind loans 5 / & 0.0 & 0.0 & 0.0 & 0.0 & 30.0 \\
\hline \multicolumn{6}{|l|}{ Memorandum items: } \\
\hline Primary overall balance (commitments) & -141.9 & -221.5 & .228 .5 & -195.2 & -218.5 \\
\hline Overall balance before grants & -267.5 & -350.2 & -329.0 & -355.6 & -425.1 \\
\hline Dormestic overall balance & -267.5 & $\ldots$ & -297.9 & -288.6 & -341.8 \\
\hline Non-interest current expenditure & 334.8 & 679.1 & 805.5 & 882.5 & 992.8 \\
\hline Non-interest curtent expenditure (casb basis) & 320.0 & 666.1 & 790.4 & 813.1 & 891.6 \\
\hline Total expenditure and net lending (cash basis) & 428.7 & 801.9 & $9 \$ 4.1$ & $1,032,4$ & $3,148.4$ \\
\hline Tax revenue (prog. def.) / current expenditure & $43.9 \%$ & $55.6 \%$ & $65.9 \%$ & $64.5 \%$ & $67.9 \%$ \\
\hline
\end{tabular}


Table 16. Georgia: Summary of General Government Operations, 1996-99

\begin{tabular}{|c|c|c|c|c|c|}
\hline & 1995 & 1996 & 1997 & 1998 & $\frac{1999}{\begin{array}{c}\text { Estimated } \\
\text { outhurn }\end{array}}$ \\
\hline & \multicolumn{5}{|c|}{ (In percent of GDP) } \\
\hline Total revenue and grants (excluding privatization) & 10.6 & 14.1 & 14.8 & 16.4 & 15.6 \\
\hline Total reverue & 7.7 & 12.2 & 14.5 & 15.4 & 14.7 \\
\hline Tax revenue \{excluding extrabudgetary\} & 5.5 & 8.4 & 10.8 & 11.0 & 11.6 \\
\hline Taxes on income & 0.9 & 1.2 & 1.7 & 1.8 & 1.9 \\
\hline Taxes on profits & 1.2 & 1.0 & 0.9 & 1.1 & 1.0 \\
\hline VAT & 2.4 & 3.6 & 4.6 & 4.6 & 4.4 \\
\hline Custom dutits & 0.2 & 0.5 & 1.4 & 1.4 & 0.6 \\
\hline Excises & 0.1 & 0.7 & 1.2 & 0.8 & 2.1 \\
\hline Other taxes & 0.7 & 1.5 & 1.1 & 1.3 & 1.6 \\
\hline Nontax revenue & 0.7 & 1.3 & 1.5 & 2.0 & 0.8 \\
\hline Extrabudgetary revenue 1/ & 1.6 & 2.4 & 2.3 & 2.5 & 2.4 \\
\hline Grants & 2.9 & 1.9 & 0.3 & 1.0 & 0.9 \\
\hline Total expenditure and net lending & 18.7 & 21.5 & 21.8 & 22.9 & 22.3 \\
\hline Current expenditure $2 t$ & 16.0 & 19.6 & 19.8 & 20.8 & 20.6 \\
\hline Wages and salaries & 2.4 & 2.8 & 3.5 & 3.7 & 3.4 \\
\hline Goods and services $3 /$ & 4.8 & 8.1 & 6.1 & 4,2 & 3.4 \\
\hline Transfers and subsidies & 1.6 & 1.6 & 2.3 & 2.5 & 2.9 \\
\hline Interest payments & 2.2 & 1.5 & 1.9 & 2.4 & 2.8 \\
\hline Domestic & 0.0 & 0.3 & 0.8 & 1.3 & 1.4 \\
\hline External & 2.2 & 1.2 & 1.0 & 1.1 & 1.4 \\
\hline Exurabudgetary expenditures 4 & 2.1 & 2.8 & 3.7 & 4.4 & 3.8 \\
\hline Local government expenditures & 2.9 & 2.9 & 2.3 & 3.6 & 4.3 \\
\hline Capital expenditure & 1.6 & 1.8 & 1.6 & 1.4 & 0.9 \\
\hline Of which: Foreign financed & & $\ldots$ & 0.4 & 0.7 & 0.8 \\
\hline Net lending & 1.1 & 0.1 & 0.4 & 0.7 & 0.9 \\
\hline Of which: Foreign fimanced & & $\ldots$ & 0.3 & 0.7 & 0.7 \\
\hline Budget contingency & 0.0 & 0.0 & 0.0 & 0.0 & 0.0 \\
\hline Overall balance (commitrnents) & -8.1 & .7 .4 & -7.0 & -6.5 & -6.7 \\
\hline Adjustment to cash basis & 1.1 & 0.2 & 0.6 & 1.3 & 1.8 \\
\hline Net change in expenditure arrears (-, reduction) & 1.1 & 0.2 & 0.6 & 13 & 1.8 \\
\hline External interest & 0.5 & -0.1 & -0.2 & -0.1 & 0.0 \\
\hline Domestic expenditure & 0.6 & 0.3 & 0.8 & 1.4 & 1.8 \\
\hline Net other cash balancing & 0.0 & 0.0 & 0.0 & 0.0 & 0.0 \\
\hline Overall balance (casb) & $-7,0$ & -7.2 & -6.3 & -5.1 & -4.9 \\
\hline Total financing & 7.0 & 7.2 & 6.3 & 5.1 & 4.9 \\
\hline Privatization & 0.1 & 0.5 & 0.6 & 1.5 & 0.9 \\
\hline Domestic & 2.4 & 4.2 & 3.6 & 2.0 & 2.2 \\
\hline XBG & $\ldots$ & $\ldots$ & $\ldots$ & 2.3 & 3.3 \\
\hline Of which: NBG recapitalization & & $\cdots$ & $\ldots$ & 0.0 & 1.3 \\
\hline Commercial banks & $\ldots$ & $\ldots$ & $\ldots$ & -0.2 & 0.0 \\
\hline Nonbank & $\ldots$ & $\ldots$ & $\ldots$ & 0.0 & 0.1 \\
\hline Offet to NBG Recapitalization & & $\ldots$ & $\ldots$ & 0.0 & -1.3 \\
\hline External & 4.4 & 2.5 & 2.2 & 1.6 & 1.2 \\
\hline Disbursements & 4.4 & 2.5 & 2.5 & 2.1 & 2.5 \\
\hline Amortization & -4.8 & -0.4 & -1.5 & .2 .4 & -3.3 \\
\hline Changes in arrears $\{-$, reduction $)$ & 4.8 & 0.4 & 1.3 & -1.5 & 2.0 \\
\hline Macroeconomic support & 0.0 & 0.0 & 0.0 & 3.4 & 0.0 \\
\hline Net U.S. in-kind loans S/ & 0.0 & 0.0 & 0.0 & 0.0 & 0.5 \\
\hline \multicolumn{6}{|l|}{ Memorandum items: } \\
\hline Tax revenue (including extrabudgetary) & 7.0 & 10.9 & 13.0 & 13.4 & 14.0 \\
\hline Primary overall balance (commitments) & -5.8 & -5.9 & .5 .1 & -4.1 & -3.9 \\
\hline Overall balance before grants & -11.0 & -9.3 & .7 .3 & -7.4 & -7.6 \\
\hline Domestic overall balance & -11.0 & $\ldots$ & -6.6 & -6.0 & -6.1 \\
\hline Non-interest curreat expenditure & 13.8 & 18.0 & 17.9 & 18.4 & 17.7 \\
\hline Non-interest current expenditure (cash basis) & 13.2 & 17.7 & 17.5 & 17.0 & 15.9 \\
\hline Total expenditure and net lending (cash basis) & 17.6 & 21.3 & 21.2 & 21.5 & 20.5 \\
\hline Nominal GDP (In lari millions) & 2432 & 3,768 & 4,505 & 4,795 & 5,594 \\
\hline
\end{tabular}

Sources: Georgian authorities; and Fund staff estimates.

W Includes revenues of the Pension Fund, Enployment Fund, Health Fund (until July 1997), and Rond Fund. Payroll tax payments made by budgetary organizations are treated as intragovernmental transfers.

$2 /$ Capital expenditures of loxal governments and the Road Fund may be included.

3/ Combines other goods and services, unclassified expenditures, and other current expenditures.

4/ Expenditures of the Pension Fund, Employment Fund, Road Fund and Health Fund (until July 1997).

$5 /$ Used for in-kind loans disbursed is 1998 or later. Given the lag between the creation of the financial liability and the delivery of the in-kind goods, positive net financing is recorded as the in-kind goods are delivered (prior to delivery, the financial liability is offset by the holding of the in-kind asset). 
Table 17. Georgia: Accounts of Extrabudgetary Funds, 1997-99 1/

(In millions of lari)

\begin{tabular}{|c|c|c|c|}
\hline & 1997 & 1998 & $\frac{1999}{\operatorname{Tan}-\operatorname{Sen}}$ \\
\hline \multicolumn{4}{|l|}{ Social Security Fund } \\
\hline Revenue & 131.0 & 149.7 & 174.3 \\
\hline Payroll taxes & 98.2 & 113.4 & 126.3 \\
\hline Transfers from state budget & 32.8 & 30.7 & 42.0 \\
\hline For pensions & 14.6 & $\cdots$ & $\cdots$ \\
\hline For child allowances & $\ldots$ & $\ldots$ & $\ldots$ \\
\hline Allowances households & $\cdots$ & $\cdots$ & $\cdots$ \\
\hline Electricity for pensioners & 18.2 & $\cdots$ & $\ldots$ \\
\hline Other & 0.0 & 5.5 & 0.6 \\
\hline Expenditure & 129.6 & 146.9 & 174.3 \\
\hline Pensions & 119.9 & 133.7 & 161.4 \\
\hline Child allowances & $\ldots$ & 1.9 & 1.0 \\
\hline Sickness allowances $2 /$ & 6.7 & 6.3 & 4.0 \\
\hline Allowances households & $\ldots$ & $\cdots$ & $\cdots$ \\
\hline Other & 2.6 & 4.5 & 4.0 \\
\hline Balance $(-$, deficit $)$ & 3.2 & 2.9 & 0.0 \\
\hline \multicolumn{4}{|l|}{ Employment Fund } \\
\hline Revenue & 1.2 & 3.2 & 3.8 \\
\hline Expenditure & 1.4 & 3.2 & 3.8 \\
\hline Unemployment benefits & 0.8 & 1.5 & 1.0 \\
\hline Job programs & 0.2 & 0.6 & 1.8 \\
\hline Education and qualification & 0.3 & 0.4 & 0.5 \\
\hline Administration & 0.3 & 0.7 & 1.0 \\
\hline Balance (-, deficit) & -0.2 & 0.0 & 0.0 \\
\hline \multicolumn{4}{|l|}{ Road Fund } \\
\hline Revenue & 34.6 & 37.4 & 35.1 \\
\hline Road user fees & 9.9 & 7.4 & 7.0 \\
\hline Oil tax & 1.0 & 12.6 & 15.0 \\
\hline Car tax & 5.3 & 4.2 & 4.5 \\
\hline Cross-border tax & 9.1 & 9.5 & 7.5 \\
\hline Advertisement tax & 0.2 & 0.1 & $\ldots$ \\
\hline Central budget allocations & 8.9 & 3.5 & 0.0 \\
\hline Expenditure & 37.4 & 37.6 & 35.1 \\
\hline Maintenance and repairs & 27.6 & 19.8 & 20.0 \\
\hline Construction & 4.8 & 16.4 & 12.6 \\
\hline Payment of arrears for 1996 & 0.0 & n.a. & n.a. \\
\hline Other & $\ldots$ & 1.4 & 1.5 \\
\hline Balance $(-$, deficit $)$ & -2.8 & -0.2 & 0.0 \\
\hline \multicolumn{4}{|l|}{ Of which: } \\
\hline financed by arrears accumulation & $\ldots$ & $\cdots$ & $\cdots$ \\
\hline
\end{tabular}

Source: Georgian authorities.

1/ The Privatization Fund is not included because detailed data on this fund's activities are not available.

$2 /$ Includes allowances for sickness, pregnancy and maternity. 


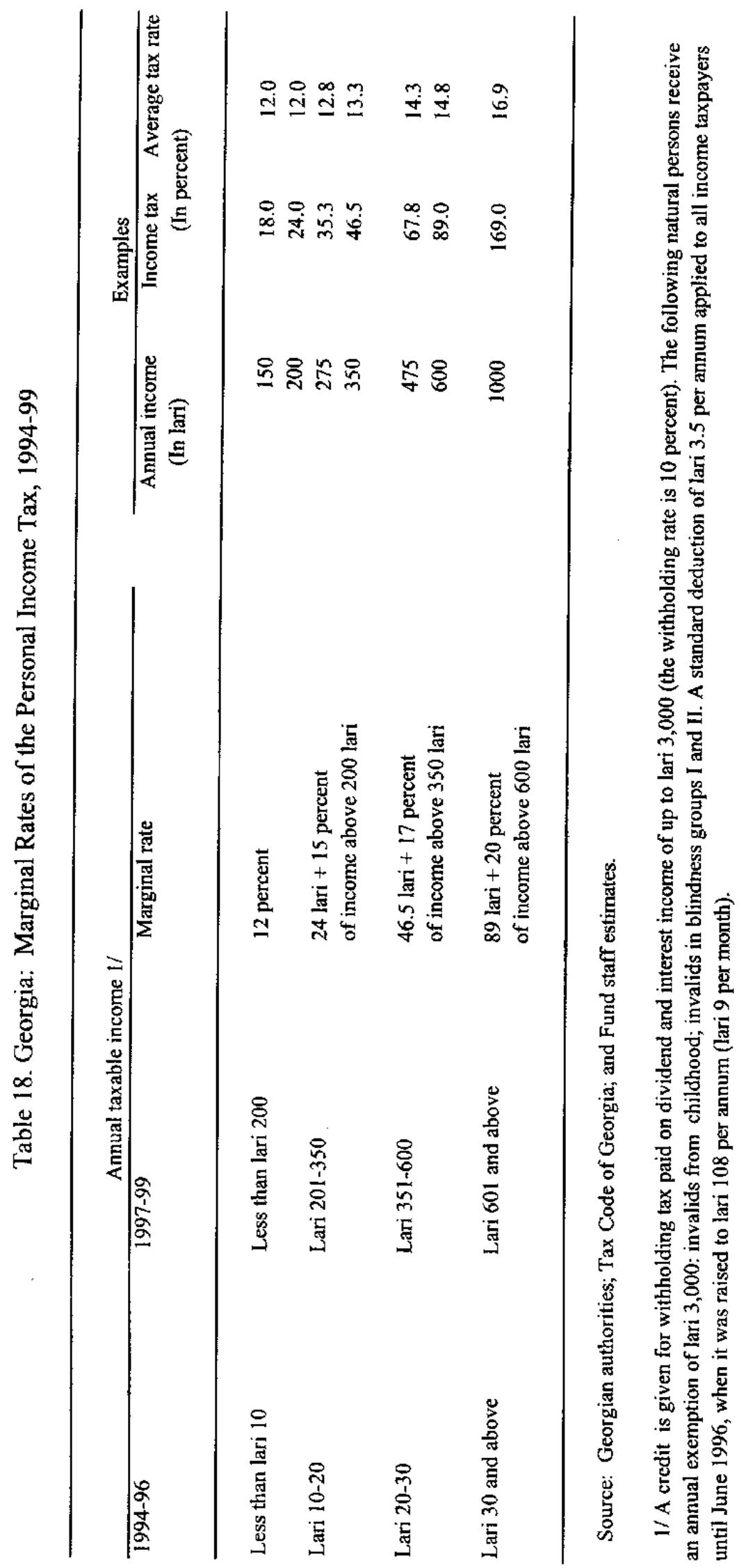




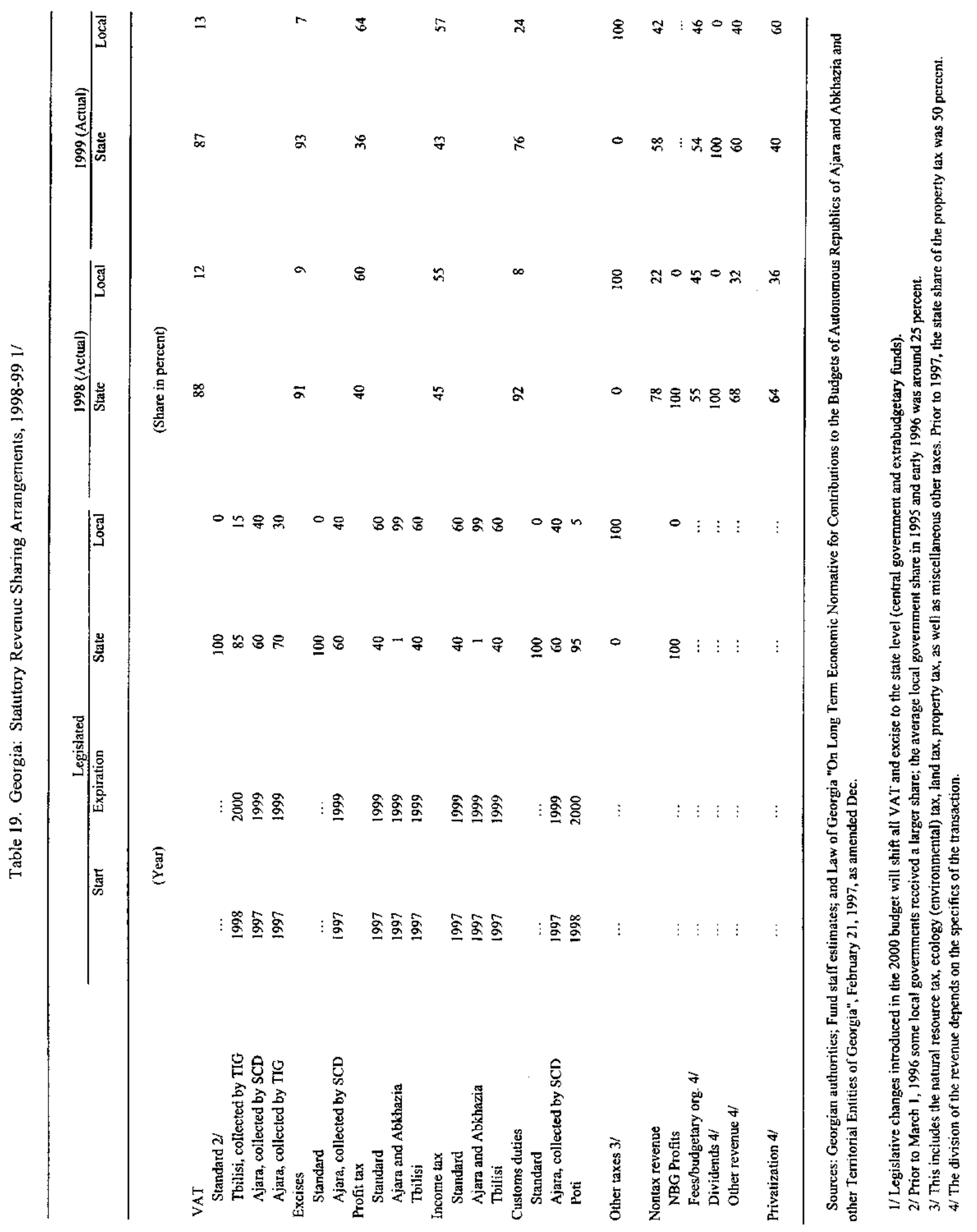




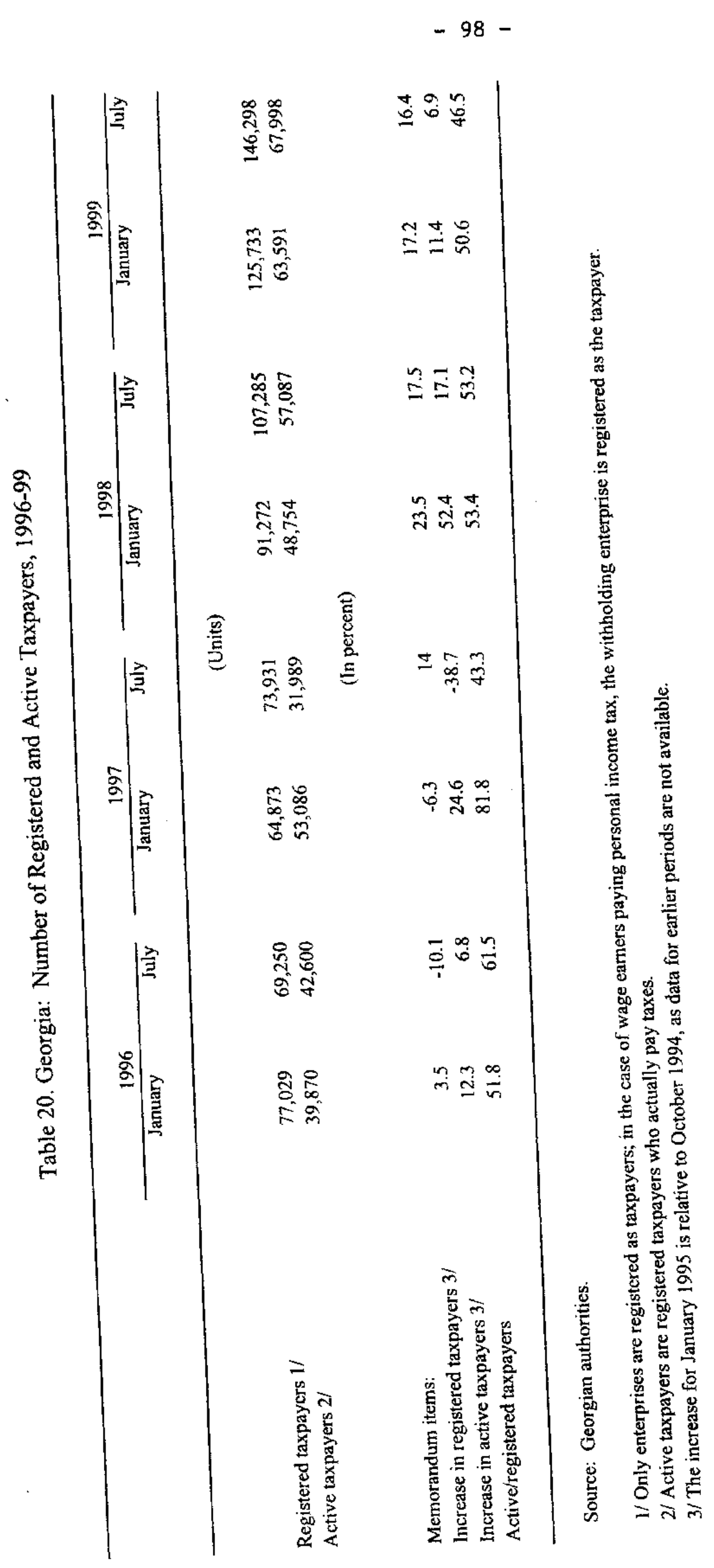

APPENDIX I 
Table 21. Georgia: Excise Tax Rates, 1998-2000 1/

\begin{tabular}{|c|c|c|c|c|c|c|c|c|}
\hline & \multirow[t]{2}{*}{ Quantity } & \multicolumn{2}{|c|}{1998} & \multicolumn{4}{|c|}{1999} & \multirow{2}{*}{$\frac{2000}{\text { Jan. }}$} \\
\hline & & May & Nov. & Jan. & Apr. & Jun. & Sep. & \\
\hline \multicolumn{9}{|l|}{ Alcohol } \\
\hline \multicolumn{9}{|l|}{ Domestic } \\
\hline Charnpagne & Litre & 4.00 & 4.00 & 4.00 & 4,00 & 4.00 & 0.50 & 0.50 \\
\hline Sparkling grape wine & Lite & 0.50 & 0.50 & 0.50 & 0.50 & 0.50 & 0.50 & 0.50 \\
\hline Sparkling fruit wire & Litre & 2.00 & 2.00 & 2.00 & 2.00 & 2.00 & 0.50 & 0.50 \\
\hline Unbottled wine & Litre & 0.10 & 0.10 & 0.10 & 0.10 & 0.10 & 0.10 & 0.10 \\
\hline Bottled wine & Litre & 0.20 & 0.20 & 0.20 & 0.20 & 0.20 & 0.20 & 0.20 \\
\hline Fruit wine & Litre & 1.70 & 1.70 & 1.70 & 1.70 & 1.70 & 2.00 & 2.00 \\
\hline Bottled fortified wine & Litre & 0.50 & 0.50 & 0.50 & 0.50 & 0.50 & 1.00 & 1.00 \\
\hline Unbottled fortified wine & Litre & 1.00 & 1.00 & 1.00 & 1.00 & 1.00 & 0.50 & 0.50 \\
\hline Mixed fortified wine & Litre & 2.00 & 2.00 & 2.00 & 2.00 & 2.00 & $\ldots$ & ... \\
\hline Cognac and cognac materials & Litre & 6.70 & 6.70 & 6.70 & 6.70 & 6.70 & 2.00 & 2.00 \\
\hline Whiskey, gin, and rum & Litre & 4.00 & 4.00 & 4.00 & 4.00 & 4.00 & 2.00 & 2.00 \\
\hline Brandy and brandy materials & Litre & 2.70 & 2.70 & 2.70 & 2.70 & 2.70 & 2.00 & 2.00 \\
\hline Vouka & Litre & 1.00 & 1.00 & 1.00 & 1.00 & 1.00 & $\{, 00$ & 1.00 \\
\hline Liqueur & Litre & 2.70 & 2.70 & 2.70 & 2.70 & 2.70 & 2.00 & 2.00 \\
\hline Othet alcoholic drinks & Litre & 1.00 & 1.00 & 1.00 & 1.00 & 1.00 & 2.00 & 200 \\
\hline Beer & Litre & 0.12 & 0.12 & 0.12 & 0.12 & 0.12 & 0.12 & 0.12 \\
\hline Ethyl spirits & Litre & 0.70 & 0.70 & 0.70 & 0.70 & 0.70 & 0.70 & 0.70 \\
\hline \multicolumn{9}{|l|}{ Imported $2 f$} \\
\hline Charnpagne & Iitse & 4.93 & 4.93 & 4.00 & 4.00 & 4.00 & 0.50 & 0.50 \\
\hline Sparkling grape wine & Litre & 0.59 & 0.59 & 0.50 & 0.50 & 0.50 & 0.50 & 0.50 \\
\hline Sparkling fruit wine & Litre & 2.47 & 2.47 & 2.00 & 2.00 & 2.00 & 0.50 & 0.50 \\
\hline Unbottled wine & Litre & 0.10 & 0.10 & 0.10 & 0.10 & 0.10 & $\ldots$ & $\cdots$ \\
\hline Bottled wine & Litre & 0.24 & 0.24 & 0.20 & 0.20 & 0.20 & $\ldots$ & $\ldots$ \\
\hline Fruit wine & Litre & 2.05 & 2.05 & 1.70 & 1.70 & 1.70 & 2.00 & 2.00 \\
\hline Botuled fortified wine & Litre & 1.23 & 1.23 & 0.50 & 0.50 & 0.50 & 1.00 & 1.00 \\
\hline Unbottled fortified wine & Litre & 0.61 & 0.61 & 1.00 & 1.00 & 1.00 & 1.00 & 1.00 \\
\hline Mixed fortified wine & Litre & 2.47 & 2.47 & 2.00 & 2.00 & 2.00 & 1.00 & 1.00 \\
\hline Cognac and cognac materials & Litre & 8.22 & 8.22 & 6.70 & 6.70 & 6.70 & 2.00 & 2.00 \\
\hline Whiskey, gin, and rum & Litre & 4.93 & 4.93 & 4,00 & 4.00 & 4,00 & 2.00 & 2.00 \\
\hline Brandy and brandy materials & Litre & 3.28 & 3.28 & 2.70 & 2.70 & 2.70 & 2.00 & 2.00 \\
\hline Vodka & Litre & 1.24 & 1.24 & 1.00 & 1.00 & $1 . \infty 0$ & 1.00 & 1.00 \\
\hline Liqueur & Litre & 3.28 & 3.28 & 2.70 & 2.70 & 2.70 & 2.00 & 2.00 \\
\hline Other alcoholic drinks & Litre & 1.24 & 1.24 & 1.00 & 1.00 & 1.00 & 2.00 & 2.00 \\
\hline Beer & Litre & 3.28 & 3.28 & 0.12 & 0.12 & 0.12 & 0.12 & 0.12 \\
\hline Ethyl spirits & Litre & 0.83 & 0.83 & 0.70 & 0.70 & 0.70 & 0.70 & 0.70 \\
\hline \multicolumn{9}{|l|}{ TobaccD products $3 /$} \\
\hline \multicolumn{9}{|l|}{ Domestic } \\
\hline Smaking tobacco & Kilogram & $\ldots$ & 20 & 20 & 20 & 20 & 20 & 20 \\
\hline Cigar & Per unit & $\ldots$ & 0.15 & 0.15 & 0.15 & 0,15 & 0.15 & 0.60 \\
\hline Cigarettes (class I and II) $4 /$ & 20 units & $100 \%$ & 0.15 & 0.15 & 0.15 & 0.15 & 0.15 & 0.40 \\
\hline Cigarettes (other) $5 /$ & 20 units & $55 \%$ & 0.05 & 0.05 & 0.05 & 0.05 & 0.05 & 0.30 \\
\hline \multicolumn{9}{|l|}{ Imported } \\
\hline Smoking tobacco & Kilogram & 20 & 20 & 20 & 20 & 20 & 20 & 20 \\
\hline Cigar & Per unit & 0.25 & 0.25 & 0.25 & 0.25 & 0.25 & 0.25 & 0.60 \\
\hline Cigarettes (class I and II) 4 / & 20 units & 0.25 & 0.25 & 0.25 & 0.25 & 0.25 & 0.25 & 0.40 \\
\hline Cigarettes (other) $5 /$ & 20 units & 0.19 & 0.19 & 0.19 & 0.19 & 0.19 & 0.19 & 0.30 \\
\hline Jewelry & Percent & 35 & 35 & 35 & 35 & 35 & 35 & 35 \\
\hline Passenger automobiles & Percent & 15 & 15 & 15 & 15 & is & 15 & 15 \\
\hline Passenges automobile tires & Percent & 15 & 15 & 15 & 15 & 15 & 15 & 15 \\
\hline Caviar & Fercent & 20 & 20 & 20 & 20 & 20 & 20 & 20 \\
\hline Ethylated automobile gas & Percent & 100 & 100 & 100 & 100 & $\ldots$ & $\ldots$ & $\ldots$ \\
\hline Non-ethylated autnmobile gas & Percent & 60 & 60 & 60 & 60 & 80 & 80 & 80 \\
\hline Other petroleum products (except mazout) & Percent & $\ldots$ & 60 & 60 & 60 & 60 & 60 & 60 \\
\hline
\end{tabular}

Source: Tax Code of Geargia.

1/ Unless denoted as percent, excises are specific and expressed in lari per unit.

$2 /$ The excise component of the combined fixed tax (that was in effect until Jantary 1, 1999) that was comprised of the import duty, excise, and VAT.

3/ Refers to a single specific tax that is paid in lieu of excise and VAT.

4/ Defined as filtered since July 19, 1999.

5/ Defined as unfiltered since July 19, 1999. 
Table 22. Georgia: Tax Arrears, 1997-99 1/

(Beginning of period)

\begin{tabular}{|c|c|c|c|c|c|c|}
\hline & \multicolumn{2}{|c|}{1997} & \multicolumn{2}{|c|}{1998} & \multicolumn{2}{|c|}{1999} \\
\hline & January & July & January & July & January & July \\
\hline & \multicolumn{6}{|c|}{ (In millions of lari) } \\
\hline Total tax arrears $2 /$ & 129.7 & 169.4 & 172.2 & 216.2 & 309.6 & 351.1 \\
\hline VAT & 17.9 & 28.2 & 47.1 & 59.7 & 102.5 & 101.1 \\
\hline Profit tax & 7.9 & 5.4 & 20.9 & 27.0 & 46.5 & 56.7 \\
\hline Personal income tax & $\ldots$ & $\ldots$ & $\ldots$ & $\ldots$ & $\ldots$ & $\ldots$ \\
\hline Excise tax & 6.8 & 5.8 & 8.6 & 16.6 & 20.2 & 22.5 \\
\hline Property tax & $\ldots$ & $\ldots$ & $\ldots$ & ... & $\cdots$ & $\ldots$ \\
\hline Land tax & 8.0 & 10.6 & 16.3 & 16.7 & 31.9 & 38.9 \\
\hline Other taxes collected by STD & 9.5 & 12.6 & 18.5 & 36.1 & 58.2 & 68.2 \\
\hline Taxes collected by Customs (SCD) & 1.7 & 3.2 & $\ldots$ & $\ldots$ & 4.8 & $\ldots$ \\
\hline Payroll taxes & 49.2 & 62,4 & 60.9 & 60.2 & 50.3 & 63.6 \\
\hline Pension Fund & 49.2 & 62.4 & 60.0 & 59.0 & 48.8 & 61.6 \\
\hline \multirow[t]{2}{*}{ Employment Fund } & ... & $\ldots$ & 0.9 & 1.2 & 1.5 & 2.0 \\
\hline & \multicolumn{6}{|c|}{ (In percent of GDP) $3 t$} \\
\hline Total tax arrears $2 /$ & 3.4 & 4.1 & 3.8 & 4.6 & 6.5 & 6.8 \\
\hline VAT & 0.5 & 0.7 & 1.0 & 1.3 & 2.1 & 1.9 \\
\hline Profit tax & 0.2 & 0.1 & 0.4 & 0.6 & 1.0 & 1.1 \\
\hline Personal income tax & $\ldots$ & $\ldots$ & $\ldots$ & $\ldots$ & $\ldots$ & $\ldots$ \\
\hline Excise tax & 0.2 & 0.1 & 0.2 & 0.4 & 0.4 & 0.4 \\
\hline Property tax & $\ldots$ & $\ldots$ & $\ldots$ & $\ldots$ & $\ldots$ & $\ldots$ \\
\hline Land tax & 0.2 & 0.3 & 0.3 & 0.4 & 0.7 & 0.7 \\
\hline Other taxes collected by STD & 0.3 & 0.3 & 0.4 & 0.8 & 1.2 & 1.3 \\
\hline Taxes collected by Customs (SCD) & $\ldots$ & $\ldots$ & $\ldots$ & $\ldots$ & 0.1 & $\ldots$ \\
\hline Payrolł taxes & 1.3 & 1.5 & 1.3 & 1.3 & 1.0 & 1.2 \\
\hline Pension Fund & 1.3 & 1.5 & 1.3 & 1.3 & 1.0 & 1.2 \\
\hline Employment Fund & $\ldots$ & $\cdots$ & 0.0 & 0.0 & 0.0 & 0.0 \\
\hline
\end{tabular}

Sources: Georgian authorities; and Fund staff estimates.

1/ The coverage of tax arrears is more complete for 1996, since arrears in contributions to the Pension Fund are included. Also, as from December 1, 1996 the data include arrears of taxes collected by the State Customs Department and payroll taxes collected by Employment Fund. Arrears to the Health Fund, the Road Fund, and some local governments taxes are excluded.

2/ The data include uspaid penalties for overdue tax payment obligations, hiding income.

3! Presented as a percentage of GDP in the preceding four quarters. 
Table 23. Georgia: Public Expenditure in Education and Health, 1997-99

\begin{tabular}{|c|c|c|c|}
\hline & 1997 & 1998 & $\frac{1999}{\text { Jan-Sep }}$ \\
\hline & \multicolumn{3}{|c|}{ (In millions of lari) } \\
\hline Education expenditure & 112.6 & 113.2 & 147.9 \\
\hline Central government & 38.3 & 30.4 & 46.5 \\
\hline Local governments & 74.2 & 82.8 & 101.4 \\
\hline Health expenditure & 41.3 & 40.4 & 57.6 \\
\hline Central government & 27.4 & 24.7 & 34.7 \\
\hline Research and experiments & 0.6 & 0.0 & 0.0 \\
\hline State health care programs & 19.9 & 13.1 & 16.3 \\
\hline Transfers to State Medical Company of Georgia & 6.8 & 11.5 & 18.5 \\
\hline \multirow[t]{2}{*}{ Local governments } & 13.9 & 15.8 & 22.9 \\
\hline & \multicolumn{3}{|c|}{ (In percent of GDP) } \\
\hline \multicolumn{4}{|l|}{ Memorandum items: } \\
\hline Education expenditure & 2.5 & 2.4 & 3.5 \\
\hline Health expenditure & 0.9 & 0.6 & 1.4 \\
\hline
\end{tabular}

Source: Georgian authorities. 
Table 24. Georgia: State Budget and Actua: Outtum, 1999

\begin{tabular}{|c|c|c|c|c|}
\hline & \multicolumn{2}{|c|}{ State butpet if } & \multicolumn{2}{|c|}{ Actual outtem } \\
\hline & In millians of lari & In percent of GDP & In millions of lari & In percent of GDF \\
\hline Total revenue and grants (excluding privatization) & 846.6 & 15.1 & 623.0 & 13.1 \\
\hline Total revenue & 760.2 & 13.6 & 574.8 & 10.3 \\
\hline Tax reverue (excluding extrabudgetary) & 561.7 & 10.0 & 417.8 & 3.5 \\
\hline Taxes on income & 36.5 & 0.7 & 45.0 & 0.8 \\
\hline Taxes on profits & 19.7 & 0.4 & 20.3 & 0.4 \\
\hline VAT & 275.4 & 4.9 & 216.6 & 3.9 \\
\hline STD & 144.0 & 2.6 & 129.8 & 2.3 \\
\hline SCD & 131.4 & 2.3 & 86.8 & 1.6 \\
\hline Custom duties & 92.3 & 1.7 & 25.7 & 0.5 \\
\hline Excises & 137.8 & 2.5 & 110.3 & 2.0 \\
\hline STD & 16.0 & 0.3 & 14.4 & 0.3 \\
\hline SCD & 121.8 & 22 & 96.0 & 1.7 \\
\hline Other taxes & 0.0 & 0.0 & 0.0 & 0.0 \\
\hline Land tax & 0.0 & 0.0 & 0.0 & 0.0 \\
\hline Mineral resources & 0.0 & 0.0 & 0.0 & 0.0 \\
\hline Environment tax & 0.0 & 0.0 & 0.0 & 0.0 \\
\hline Property tax & 0.0 & 0.0 & 0.0 & 0.0 \\
\hline Tax an transfer of property & 0.0 & 0.0 & 0.0 & 0.0 \\
\hline Local taxes & 0.0 & 0.0 & 0.0 & 0.0 \\
\hline Nontax sevenue & 47.3 & 0.8 & 24.8 & 0.4 \\
\hline Extrabudgetary revenue & 151.2 & 2.7 & 132.2 & 2.4 \\
\hline SSF (excluding budgetary payroll) & 112.3 & 2.0 & 94.6 & 1.7 \\
\hline $\mathrm{EF}$ & 3.8 & 0.1 & 4.0 & 0.1 \\
\hline Road Fund & 35.1 & 0.6 & 33.6 & 0.6 \\
\hline Of which: Gasoline excise & 0.0 & 0.0 & 11.9 & 0.2 \\
\hline Grants & 86.4 & 1.5 & 48.2 & 0.9 \\
\hline Total expenditure and net lending & $1,027.4$ & 18.4 & 958.2 & 17.1 \\
\hline Current expenditure & 885.5 & 15.8 & 859.8 & 15.4 \\
\hline Wages and salaries & 99.2 & 1.8 & 102.5 & 1.8 \\
\hline Goods and services & $2 \llbracket 4.5$ & 3.8 & 188.5 & 3.4 \\
\hline Transfers and subsidies & 188.2 & 3.4 & 198.6 & 3.6 \\
\hline Interest payments & 172.3 & 3.1 & 158.4 & 2.8 \\
\hline Domestic & 87.1 & I.6 & 80.5 & 1.4 \\
\hline Extemal & 85.2 & 1.5 & 77.9 & 1.4 \\
\hline Extrabudgetary expenditures & 211.3 & 3.8 & 211.7 & 3.8 \\
\hline SSF & 172.4 & 3.1 & 174.0 & 3.1 \\
\hline EF & 3.8 & 0.1 & 4.1 & 0.1 \\
\hline Rosd Fund & 35.1 & 0.6 & 33.6 & 0.5 \\
\hline Capital expenditure & 101.2 & 1.8 & 49.3 & 0.9 \\
\hline Of which : Foreign financed & 73.8 & 1.3 & 43.7 & 0.8 \\
\hline Net lending & 40.7 & 0.7 & 49.2 & 0.9 \\
\hline Of which : Foreign financed & 56.6 & 1.0 & 39.7 & 0.7 \\
\hline Budget contingency & 0.0 & 0.0 & 0.0 & 0.0 \\
\hline Overail balance (commitments) & -180.8 & -3.2 & -335.2 & .6 .0 \\
\hline Adjustment to cash basis & -90.0 & -1.6 & 92.6 & 1.7 \\
\hline Extemal interest. & 0.0 & 0.0 & 0.0 & 0.0 \\
\hline Donestic expenditure & -90.0 & .16 & 92.6 & 1.7 \\
\hline Net other cash balancing & 0.0 & 0.0 & 0.0 & 0.0 \\
\hline Overall balance (cash) & -270.8 & -4.8 & -242.6 & -4.3 \\
\hline Total financing & 270.8 & 4.8 & 242.6 & 4.3 \\
\hline Privatization & 60.0 & 1.1 & 21.0 & 0.4 \\
\hline Damestic & 24.5 & 0.4 & 124.2 & 2.2 \\
\hline External & 156.2 & 2.8 & 68.8 & 3.2 \\
\hline Net U.S. in-kind̆ loans & 30.0 & 0.5 & 28.6 & 0.5 \\
\hline Financing gap & 0.0 & 0.0 & 0.0 & 0.0 \\
\hline \multicolumn{5}{|l|}{ Memorandum iterns: } \\
\hline GDP (in millions of lari) & $5,593.8$ & & & \\
\hline Number of employees & $143,000.0$ & & & \\
\hline
\end{tabular}

Sources: Georgian authorities; and Furd staff estimates

1/ As originally approved by the Parlianent in March 1999. 
Table 25. Georgia: Monetary Survey, 1996-99 1/

\begin{tabular}{|c|c|c|c|c|c|c|c|}
\hline & \multirow{2}{*}{$\frac{1996}{\text { Dec. }}$} & \multirow{2}{*}{$\begin{array}{l}1997 \\
\text { Dec. }\end{array}$} & \multirow{2}{*}{$\frac{1998}{\text { Dec. }}$} & \multicolumn{4}{|c|}{1999} \\
\hline & & & & Mas. & Jun. & Sep. & Dec. \\
\hline & \multicolumn{7}{|c|}{ (Stocks, end-of-period; in millions of lari) } \\
\hline Net foreign assets & -19.0 & $-73,0$ & -319.0 & -415.4 & -359.8 & -348.2 & -375.7 \\
\hline Net domestic assets & 275.2 & 446.0 & 687.5 & 818.9 & 772.6 & 790.9 & 820.3 \\
\hline Domestic credit & 364.0 & 568.1 & 732.1 & 900.1 & 919.4 & 967.5 & 1007.6 \\
\hline Net claims on general government 2 & 235.8 & 395.2 & 493.9 & 608.2 & 635.5 & 671.6 & 688.5 \\
\hline Credit to the rest of the economy & 128.2 & 172.9 & 238.2 & 291.9 & 283.8 & 295.9 & 319.2 \\
\hline Other items, net $2 /$ & -88.8 & -122.1 & -44.6 & -81.1 & -146.7 & -176.5 & -187.3 \\
\hline Broad money (M3) & 256.3 & 373.0 & 368.5 & 403.5 & 412.8 & 442.7 & 444.6 \\
\hline Broad money, excluding foreign exchange deposits (M2) & 218.0 & 295.2 & 261.1 & 254.1 & 258.0 & 288.0 & 286.1 \\
\hline Currency held by the public & 176.8 & 239.9 & 212.2 & 206.9 & 211.6 & 240.9 & 244.0 \\
\hline Currency in circulation (M0) & 185.6 & 254.6 & 222.0 & 221.7 & 224.9 & 253.4 & 259.8 \\
\hline Less: Banks' vauit cash & -8.8 & -14.7 & -9.8 & -14.8 & -13.3 & -12.4 & -15.8 \\
\hline Deposit liabilities (domestic currency) & 41.2 & 55.3 & 48.9 & 47.2 & 46.3 & 47.1 & 42.1 \\
\hline Foreign currency deposits & 38.3 & 77.8 & 107.4 & 149.4 & 154.8 & 154.7 & 158.4 \\
\hline \multirow[t]{2}{*}{ Total deposit liabilities } & 79.5 & 133.2 & 156.3 & 196.6 & 201.2 & 201.8 & 200.6 \\
\hline & \multicolumn{7}{|c|}{ (Flows, with respect to end of previous period; in millions of lari) } \\
\hline Net foreign assets & -36.7 & -54.0 & -246.0 & .96 .4 & 55.6 & 11.6 & -27.6 \\
\hline Net domestic assets & 112.3 & 170.8 & 241.5 & 131.4 & -46.3 & 18.3 & 29.4 \\
\hline Domestic credit & 135.9 & 204.1 & 164.0 & 168.0 & 19.3 & 48.1 & 40.2 \\
\hline Net claims on general government & 156.7 & 159.4 & 98.8 & 114.2 & 27.3 & 36.1 & 16.9 \\
\hline Credit to the rest of the economy & -20.8 & 44.7 & 65.2 & 53.7 & -8.1 & 12.1 & 23.3 \\
\hline Other items, net & -23.5 & -33.3 & 77.5 & -36.6 & -65.6 & -29.8 & -10.8 \\
\hline Broad money (M3) & 75.7 & 116.8 & .4 .5 & 35.0 & 9.3 & 30.0 & 1.8 \\
\hline Broad money, excluding foreign exchange deposits (M2) & 60.3 & 79.3 & -34.1 & -7.0 & 3.9 & 30.0 & -1.9 \\
\hline \multirow[t]{2}{*}{ Foreign currency deposits } & 15.4 & 39.5 & 29.6 & 42.0 & 5.4 & -0.1 & 3.7 \\
\hline & \multicolumn{7}{|c|}{ (Change, as a percent of broad money at the end of the previous year) } \\
\hline \multirow[t]{2}{*}{ Net foreign assets } & -20.3 & -21.1 & -66.0 & -26.2 & -11.1 & .7 .9 & -15.4 \\
\hline & \multicolumn{7}{|c|}{ (Percentage change with respect to the end of the previous year) } \\
\hline Net domestic assets & 69.0 & 62.1 & 54.1 & 19.1 & 12.4 & 15.0 & 19.3 \\
\hline Broad money (M3) & 41.9 & 45.6 & $-1,2$ & 9.5 & 12.0 & 20.1 & 20.6 \\
\hline Broad money, excluding foreign exchange deposits (M2) & 38.2 & 35.4 & -11.6 & -2.7 & -1.2 & 10.3 & 9.6 \\
\hline \multicolumn{8}{|l|}{ Memorandum items: } \\
\hline M3 multiplier $3 i$ & 1.23 & 1.35 & 1.42 & 1.54 & 1.55 & 1.48 & 1.44 \\
\hline M3 velocity 4 & 15.1 & 12.4 & 12.6 & 11.7 & 14.4 & 14.4 & 12.0 \\
\hline
\end{tabular}

Source: National Bank of Georgia; and Fund staff estimates.

$1 /$ Valued at end-period actual exchange rates.

2/ Data for end-March 1999 reflect the issuance of a lari 70.3 million government bond to recapitalize the NBG for losses from revaluation of its international reserves. Data for end-June through end-1999 refiect an estimate of direct bortowing by the govemment from the commercial banks. 3/ M3 divided by reserve money.

4/ Annualized quarterly GDP divided by end-quarter M3. 
Table 26. Georgia: Accounts of the National Bank of Georgia, 1996-99 1/

\begin{tabular}{|c|c|c|c|c|c|c|c|}
\hline & \multirow{2}{*}{$\frac{1996}{\text { Dec. }}$} & \multirow{2}{*}{$\frac{1997}{\text { Dec. }}$} & \multirow{2}{*}{$\frac{1998}{\text { Dec. }}$} & \multicolumn{4}{|c|}{1999} \\
\hline & & & & Mar. & Jun. & Sep. & Dec. \\
\hline & \multicolumn{7}{|c|}{ (Stocks, end-of-period; in millions of lari) } \\
\hline Net foreign assets & -41 & -106 & -332.7 & -416.7 & -363.3 & .348 .1 & -369.4 \\
\hline Encumbered reserves & 0 & 0 & 0 & 0 & 0 & 46.321 & 0 \\
\hline Net international reserves & -41.0 & -106.0 & .332 .7 & -416.7 & .363 .3 & -348.1 & -369.4 \\
\hline Gold & 1.5 & 0.7 & 1.0 & 1.1 & 0.9 & 1.0 & 1.0 \\
\hline Foreign exchange reserves & 201.5 & 225.9 & 213.2 & 219.3 & 176.1 & 261.2 & 247.9 \\
\hline Use of Fund Resources & -244.0 & -332.0 & -546.3 & -636.4 & -539.4 & .609 .3 & -617.4 \\
\hline Other foreign assets, net & -0.1 & -0.6 & -0.6 & -0.7 & -1.0 & -1.0 & -1.0 \\
\hline Contingent liabilities & 0.0 & 0.0 & 0.0 & 0.0 & 0.0 & $-46.32 /$ & 0.0 \\
\hline Net domestic assets & 250.0 & 383.0 & 592.5 & 679.4 & 630.4 & 647.2 & 677.9 \\
\hline Net claims on general government $3 /$ & 249.0 & 398.1 & 507.9 & 621.7 & 640.8 & 674.3 & 695.0 \\
\hline Claims on banks & 13.7 & 3.5 & 6.6 & 3.6 & 2.5 & 0.9 & 1.9 \\
\hline Other items, net $3 /$ & -12.7 & -18.5 & 78.0 & 54.1 & -12.9 & -28.0 & -19.0 \\
\hline Reserve money & 209.0 & 277.1 & 259.7 & 262.7 & 267.1 & 299.1 & 308.5 \\
\hline Currency in circulation & 185.6 & 254.6 & 222.0 & 221.7 & 224.9 & 253.4 & 259.8 \\
\hline Required reserves & 13.7 & 15.7 & 18.1 & 28.8 & 31.7 & 30.8 & 29.7 \\
\hline \multirow[t]{2}{*}{ Balances on banks' correspondent a/cs } & 9.7 & 6.9 & 19.7 & 12.2 & 10.4 & 15.0 & 19.0 \\
\hline & \multicolumn{7}{|c|}{ (Flows, with respect to end of previous period; in millions of lari) } \\
\hline Net foreign assets & -98.1 & -65.0 & -226.7 & .84 .0 & 53.4 & 15.2 & -21.3 \\
\hline Net international reserves & .98 .1 & -65.0 & -226.7 & -84.0 & 53.4 & 15.2 & -21.3 \\
\hline Net domestic assets & 153.2 & 133.1 & 209.5 & 86.9 & -49.0 & 16.8 & 30.7 \\
\hline Net claims on general government & 154.4 & 149.1 & 109.8 & I 13.8 & 19.1 & 33.5 & 20.7 \\
\hline Claims on banks & 9.5 & -10.3 & 3.1 & -3.0 & -1.1 & -1.6 & 0.9 \\
\hline Other items, net & -10.7 & -5.8 & 96.5 & .23 .9 & -67.0 & -15.1 & 9.0 \\
\hline Reserve money & 55.2 & 68.1 & -17.4 & 3.0 & 4.4 & 32.0 & 9.4 \\
\hline Currency in circulation & 54.2 & 69.0 & -32.6 & -0.3 & 3.2 & 28.4 & 6.4 \\
\hline Required reserves & 1.8 & 1.9 & 2.4 & 10.7 & 2.9 & -0.9 & -1.1 \\
\hline \multirow[t]{2}{*}{ Balances on banks' correspondent a/cs } & -0.8 & -2.8 & 12.8 & -7.5 & -1.8 & 4.5 & 4.1 \\
\hline & \multicolumn{7}{|c|}{ (Change, as a percent of reserve money at the end of previous year) } \\
\hline \multicolumn{8}{|l|}{ Net foreign assets } \\
\hline \multirow[t]{2}{*}{ Net international reserves } & -63.8 & -31.1 & .81 .8 & -32.3 & -11.8 & -5.9 & -14.1 \\
\hline & \multicolumn{7}{|c|}{ (Percentage change, with respect to the end of the previous year) } \\
\hline Net domestic assets & 158.4 & 53.2 & 54.7 & 14.7 & 6.4 & 9.2 & 14.4 \\
\hline Reserve money & 35.9 & 32.6 & -6.3 & 1.2 & 2.9 & 15.2 & 18.8 \\
\hline Currency in circulation & 41.2 & 37.2 & -12.8 & -0.1 & 1.3 & 14.1 & 17.0 \\
\hline
\end{tabular}

Source: National Bank of Georgia.

1/ Valued at end-of-period actual exchange rates.

2/ US\$25 million earmarked in the 1999 budget as partial payment to Turkmenistan in lieu of principal obligations falling due are escrowed in an NBG account.

3/ Data for end-March 1999 reflect the issuance of a lari 70.3 million government bond to recapitalize the NBG for losses from revaluation of its net international reserves. 
Table 27. Georgia: Summary Accounts of Commercial Banks, 1996-99 1/

(In millions of lari)

\begin{tabular}{|c|c|c|c|c|c|c|c|}
\hline & \multirow{2}{*}{$\frac{1996}{\text { Dec. }}$} & \multirow{2}{*}{$\frac{1997}{\text { Dec. }}$} & \multirow{2}{*}{$\frac{1998}{\text { Dec. }}$} & \multicolumn{4}{|c|}{1999} \\
\hline & & & & Mar. & Jun. & Sep. & $\overline{\text { Dec. }}$ \\
\hline Net foreign assets & 22.1 & 33.0 & 13.8 & 1.3 & 3.5 & -0.1 & -6.3 \\
\hline NFA convertible & 22.0 & 32.7 & 13.7 & 1.1 & 2.8 & .0 .5 & -6.7 \\
\hline Gold & 0.2 & 1.1 & 0.5 & 0.2 & 0.1 & 0.1 & 0.2 \\
\hline Foreign exchange & 27.9 & 47.2 & 82.8 & 87.4 & 89.7 & 91.8 & 93.1 \\
\hline Foreign liabilities & -6.1 & -15.6 & -69.7 & -86.5 & -87.0 & -92.4 & -100.0 \\
\hline NFA nonconvertible & 0.1 & 0.3 & 0.1 & 0.1 & 0.7 & 0.4 & 0.4 \\
\hline Net domestic assets & 57.5 & 100.2 & 142.6 & 195.3 & 197.7 & 201.9 & 206.9 \\
\hline Domestic credit & 115.0 & 170.0 & 224.2 & 278.3 & 278.6 & 293.2 & 312.6 \\
\hline Net claims on general government & -13.2 & -2.9 & -14 & -13.6 & -5.3 & .2 .8 & -6.6 \\
\hline Net claims on republican government $2 /$ & -6.7 & 0.4 & -5.9 & -8.4 & 0.1 & 3.8 & -0.9 \\
\hline Claims on private sector & 128.2 & 172.9 & 238.2 & 291.9 & 283.8 & 295.9 & 319.2 \\
\hline Of which: foreign exchange loans & 45.0 & 77.0 & 154.4 & 204.2 & 206.3 & 218.0 & 234.9 \\
\hline Other assets (net) & -57.5 & -69.9 & -81.6 & -83.0 & -80.9 & -91.2 & -105.7 \\
\hline Deposit liabilities & 79.5 & 133.2 & 156.4 & 196.6 & 201.2 & 201.8 & 200.6 \\
\hline Domestic currency deposits & 41.2 & 55.3 & 48.9 & 47.2 & 46.3 & 47.1 & 42.1 \\
\hline Foreign currency deposits & 38.3 & 77.8 & 107.4 & 149.4 & 154.8 & 154.7 & 158.4 \\
\hline \multicolumn{8}{|l|}{ Memorandum items: } \\
\hline Share of foreign exchange deposits & 48.2 & 58.4 & 68.7 & 76.0 & 77.0 & 76.7 & 79.0 \\
\hline Exchange rate (in lari, end-of-period) & 1.3 & 1.3 & 1.8 & 2.2 & 1.9 & 1.9 & 1.9 \\
\hline
\end{tabular}

Source: National Bank of Georgia.

1/ Valued at end-period actual exchange rates.

2/ Data for end-June through end-December 1999 reflect an estimate of direct borrowing by the government from commercial banks. 


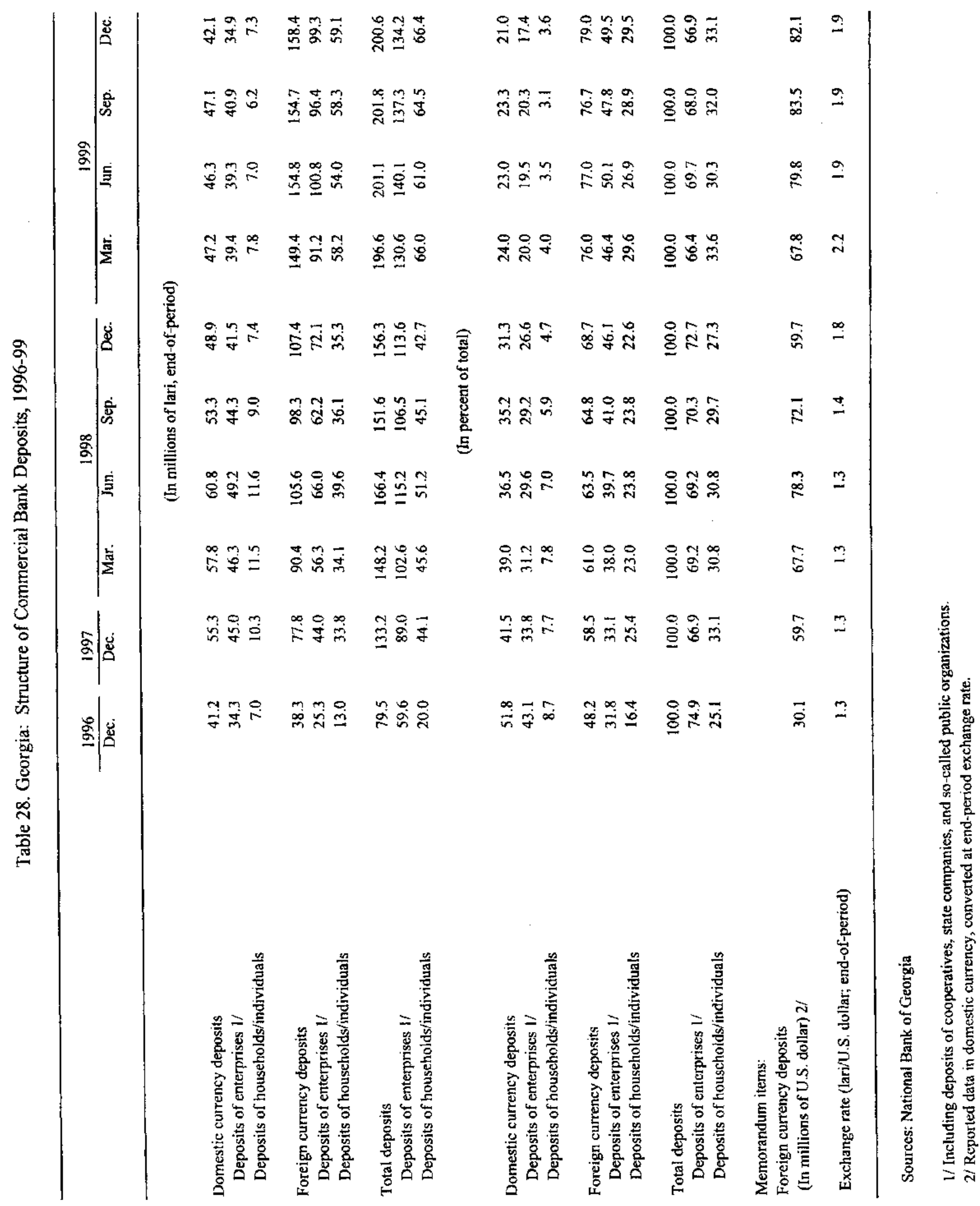


Table 29. Georgia: Currency Composition of Commercial Bank Credit, 1996-99 1/

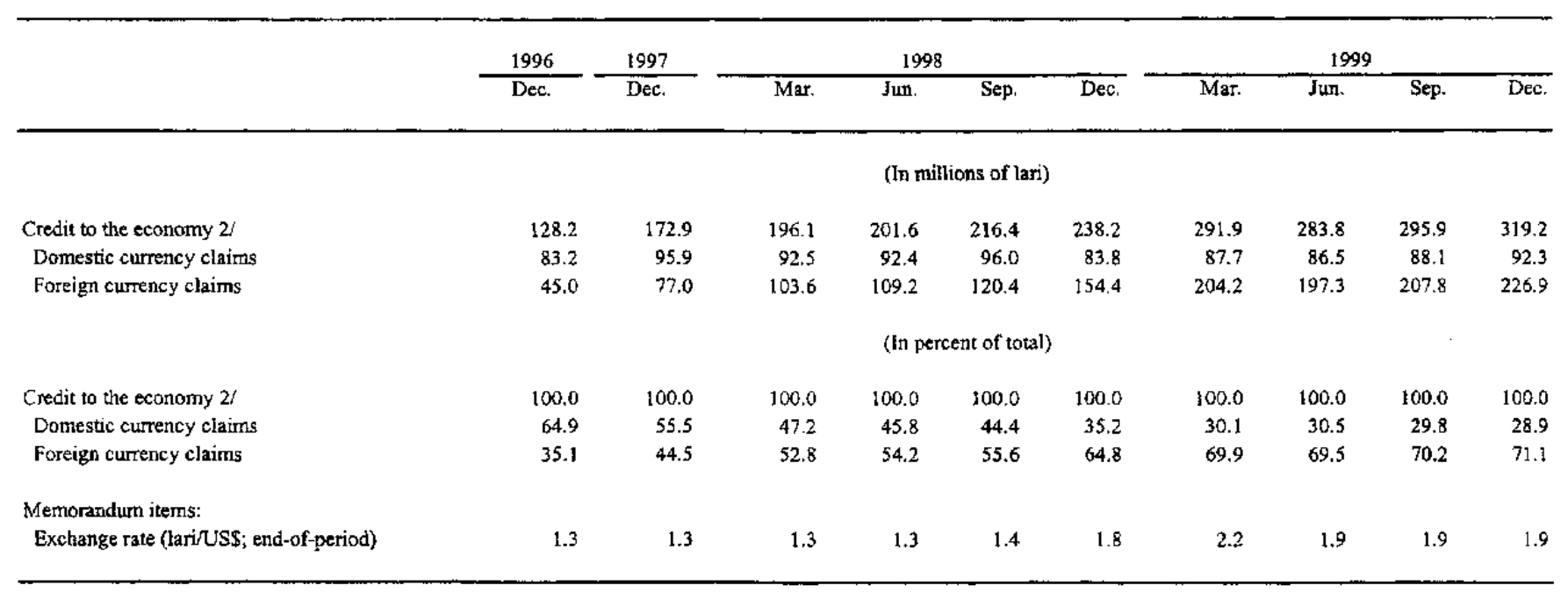

Source: National Bank of Georgia

1/ Excluding claims of the Savings Bank before July 1995.

2/ Credit to the nongovernment sectors. 
Table 30. Georgia: Regulatory Framework for Commercial Banks

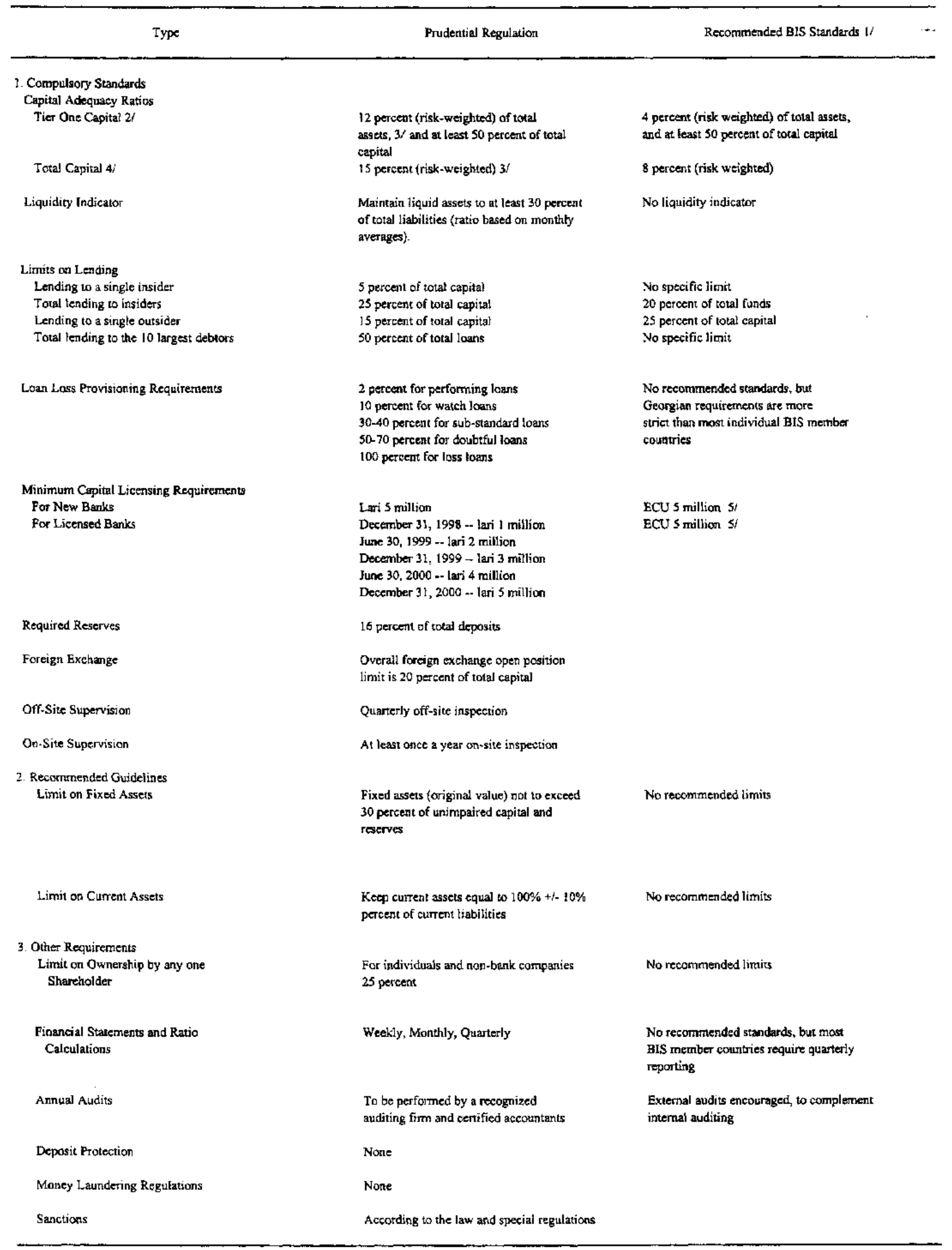

Sources: National Bank of Georgia; and Fund staff estimates.

1/ BIS (Bank for International Settiements) recormunended standards, which were adopted in September 1997, are the minimum requirements.

$2 /$ "Tier One Capital" includes: (I) common share capital; (II) Recained eanings; (III) capital surplus; (IV) less revaluation of fixed assets recorded in share capital; (V) less any treasury stocks; (VI) less intangible assets, goodwill.

3/ Regulations on classification of assets by the underlying tisk is effective from January ], 1999

4/ "Total Capital" inciudes: (1) tier one capital plus (II) ties two capital; (IIT) less investments in Georgian resident Banks capital; (IV) less non-consolidated inyestments in subsidiaries capital

5/ Represents the minimum capiral standird adopted by EU member countries; no BIS recomnended limits availabie on minimutn capital. 


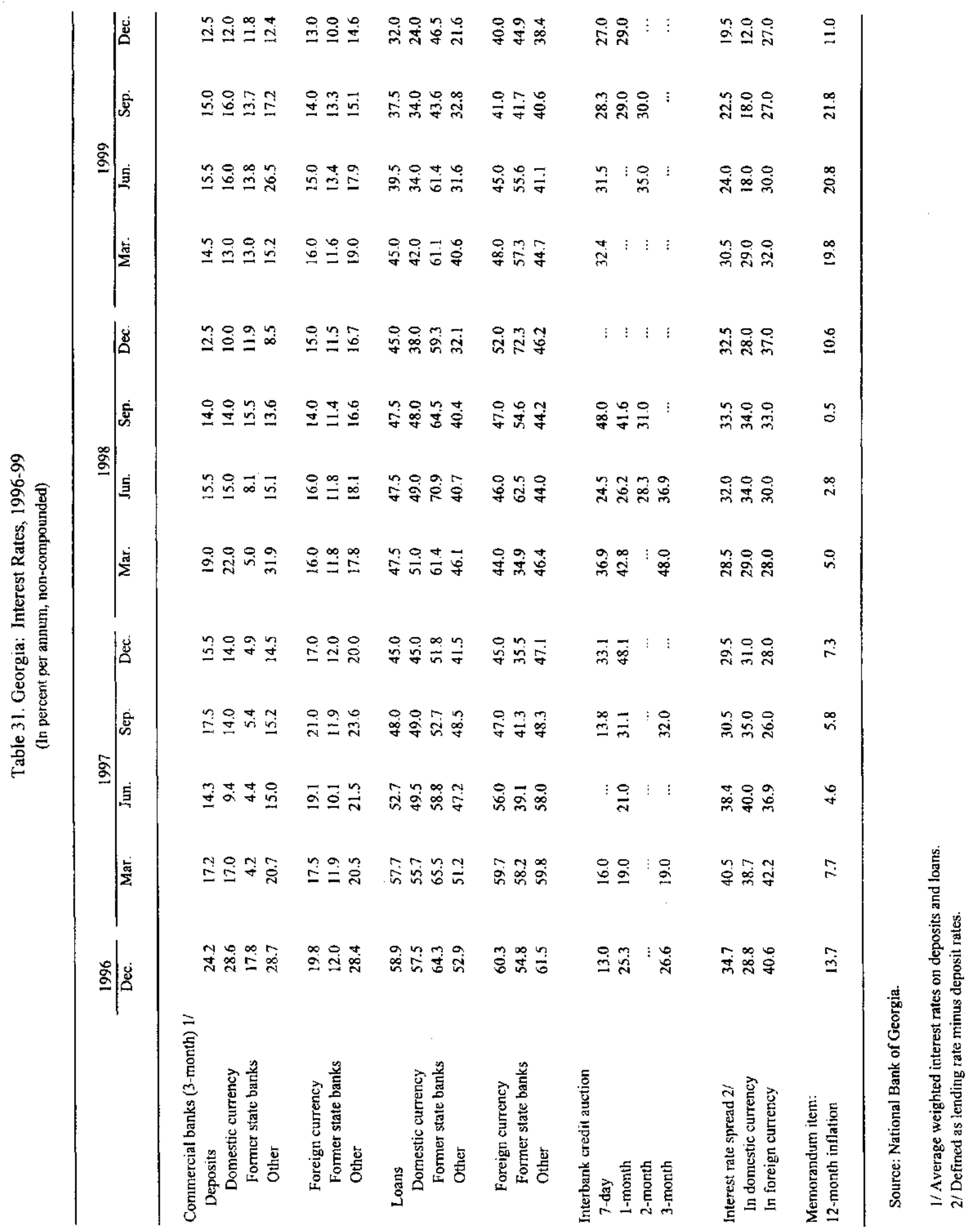


Table 32. Georgia: Balance of Payments, 1995-99

(In millions of U.S. dollars; unless otherwise indicated)

\begin{tabular}{|c|c|c|c|c|c|}
\hline & \multirow[t]{2}{*}{1995} & \multirow[t]{2}{*}{1996} & \multirow{2}{*}{$\frac{1997}{\text { Est. }}$} & 1998 & 1999 \\
\hline & & & & \multicolumn{2}{|c|}{ Prel. } \\
\hline Current account (excluding transfers) & -404.8 & -415.4 & -571.3 & -599.3 & -395.0 \\
\hline Trade balance $1 /$ & -337.4 & -350.9 & -558.9 & -685.4 & -528.2 \\
\hline Exports & 362.6 & 417.0 & 493.5 & 478.3 & 484.8 \\
\hline Imports & -700.1 & -767.9 & $-1,052.4$ & $-1,163.7$ & $-1,013.0$ \\
\hline Non-factor services & 17.0 & -5.1 & -148.0 & -31.1 & 16.3 \\
\hline Credits & 121.8 & 93.9 & 167.9 & 242.1 & 263.5 \\
\hline Debits & -104.8 & -99.1 & -315.9 & -273.2 & -247.3 \\
\hline Factor services & -84.4 & -59.3 & 135.6 & 117.2 & 116.9 \\
\hline Credits & 1.0 & 4.9 & 186.6 & 193.3 & 204.1 \\
\hline Debits & -85.4 & -64.3 & -51.0 & .76 .1 & -87.3 \\
\hline Transfers & 189.2 & 140.5 & 1964 & 210.7 & 174.6 \\
\hline Capital account & -94.2 & 90.7 & 267.8 & 251.2 & 129.9 \\
\hline Medium- and long-term borrowing & -178.9 & 28.8 & 53.1 & 33.3 & 52.4 \\
\hline Disbursements & 89.5 & 112.4 & 106.6 & 112.4 & 144.5 \\
\hline Amortization due & -268.4 & -83.6 & -53.5 & -79.0 & -92.1 \\
\hline Other capital & 84.7 & 61.8 & 214.7 & 217.9 & 77.5 \\
\hline Errors and omissions & 6.2 & 15.5 & 5.1 & 10.2 & 22.2 \\
\hline Overall balance & -303.6 & -168.7 & -102.0 & -127.1 & -68.3 \\
\hline Overall financing & 303.6 & 168.7 & 102.0 & 127.1 & 68.3 \\
\hline Increase in net international reserves (-) 2 / & -40.7 & 79.2 & 61.0 & 91.1 & 14.5 \\
\hline Exceptional financing 3 i & 344.3 & 89.6 & 41.1 & 36.0 & 53.8 \\
\hline \multicolumn{6}{|l|}{ Memorandum items: } \\
\hline Current account excluding transfers (in percent of GDP) & 21.3 & 13.8 & 16.5 & 17.5 & 14.1 \\
\hline Gross usable reserves & 156.7 & 158.0 & 173.3 & 118.4 & 128.5 \\
\hline In months of imports & 2.7 & 2.5 & 2.0 & 1.2 & 1.5 \\
\hline Debt service due & 34.9 & 47.2 & 39.7 & 122.3 & 164.0 \\
\hline In percent of exports of goods and non-factor services & 7.2 & 9.2 & 6.0 & 17.0 & 21.9 \\
\hline Stock of external debt & $1,211.5$ & $1,352.4$ & $1,515.7$ & $1,636.4$ & $1,753.6$ \\
\hline In percent of GDP & 63.7 & 44.9 & 43.6 & 47.9 & 62.7 \\
\hline
\end{tabular}

Sources: Georgian State Department and Statistics; and Fund staff estimates.

1/ There have been significant changes in the coverage of trade data and, as a result, caution is needed in comparing annual totals.

2/ Includes a valuation adjustment.

$3 i$ Includes arrears, debt relief, and macroeconomic support. 
Table 33. Georgia: Geographic Distribution of Trade, by Country, 1998-99 1/ (In percent of total)

\begin{tabular}{|c|c|c|}
\hline & 1998 & 1999 \\
\hline \multicolumn{3}{|l|}{ Exports } \\
\hline Total & 100.0 & 100.0 \\
\hline Russia & 28.7 & 18.7 \\
\hline Turkey & 10.5 & 15.8 \\
\hline Azerbaijan & 9.6 & 8.1 \\
\hline Armenia & 9.3 & 6.3 \\
\hline Germany & 6.9 & 10.3 \\
\hline United States & 5.8 & 4.2 \\
\hline Italy & 4.7 & 4.5 \\
\hline Ukraine & 4.4 & 4.6 \\
\hline France & 3.2 & 0.3 \\
\hline Switzerland & 2.8 & 2.4 \\
\hline Netherlands & 1.7 & 0.9 \\
\hline Bulgaria & 1.6 & 0.2 \\
\hline Others & 10.8 & 23.7 \\
\hline \multicolumn{3}{|l|}{ Imports } \\
\hline Total & 100.0 & 100.0 \\
\hline Russia & 14.8 & 19.2 \\
\hline Turkey & 11.1 & 12.2 \\
\hline Azerbaijan & 8.3 & 6.9 \\
\hline Germany & 9.3 & 7.3 \\
\hline United Kingdom & 7.7 & 3.5 \\
\hline United States & 8.6 & 11.9 \\
\hline Switzerland & 3.7 & 0.2 \\
\hline Ukraine & 3.5 & 4.5 \\
\hline Bulgaria & 3.1 & 1.9 \\
\hline Italy & 3.3 & 2.0 \\
\hline Netherlands & 2.9 & 2.0 \\
\hline France & 2.5 & 5.0 \\
\hline Romania & 2.1 & 2.1 \\
\hline Others & 19.1 & 21.3 \\
\hline
\end{tabular}

Source: Georgian State Department of Statistics.

1/ Refers to trade as recorded by the Customs Department in 1998. 
Table 34. Georgia: Composition of Major Exports, 1995-98 1/

(In millions of U.S. dollars)

\begin{tabular}{|c|c|c|c|c|}
\hline & 1995 & 1996 & 1997 & 1998 \\
\hline Ferro alloys & 23.6 & 7.7 & 15.5 & 22.3 \\
\hline Non-ferrous metal pipes & 14.2 & 15.7 & 17.5 & 6.4 \\
\hline Crude oil and related oil products & $\ldots$ & 6.7 & 14.4 & $\ldots$ \\
\hline Oil and oil products & 8.4 & 17.4 & 13.4 & 9.2 \\
\hline Tea & 8.4 & 16.8 & 18.5 & 8.9 \\
\hline Fertilizers & 8.1 & 11.9 & 13.8 & 10.6 \\
\hline Citnus fruits (including dry fruits) & 6.9 & 8.2 & 9.1 & 9.5 \\
\hline Copper ore & 5.9 & 13.4 & 14.1 & 15.1 \\
\hline Alcoholic beverage (excluding wine) & 4.1 & 6.3 & 5.2 & 5.5 \\
\hline Wine and related products & 3.5 & 12.5 & 12.5 & 15.4 \\
\hline Non alloyed steel and cast iron & 3.3 & 10.2 & 9.3 & 6.2 \\
\hline Mineral water & $\ldots$ & 17.5 & 18.5 & 7.2 \\
\hline Electricity & $\ldots$ & 13.1 & 11.9 & $\ldots$ \\
\hline Total & 86.4 & 157.4 & 173.7 & 116.3 \\
\hline As a percent of total exports & 57.0 & 79.1 & 72.4 & 60.5 \\
\hline \multicolumn{5}{|l|}{ Memorandum item: } \\
\hline Total exports & 151.7 & 198.9 & 239.8 & 192.3 \\
\hline
\end{tabular}

Source: Georgian State Department of Statistics.

1/ The analysis is based on raw data provided by the State Department of Statistics, Tbilisi, Georgia. Data on total exports differs significantly from staff estimates in the balance of payments table. This is because the official balance of payments statistics are extremely weak, with significant under reporting and under valuation of exports. 
Table 35. Georgia: Composition of Major Imports, 1995-98 1/ (In millions of U.S. dollars)

\begin{tabular}{|c|c|c|c|c|}
\hline & 1995 & 1996 & 1997 & 1998 \\
\hline Oil and oil products (excluding crude oil) & 113.4 & 160.0 & 152.2 & 130.3 \\
\hline Oil, gas, and related products & 75.1 & 87.9 & 75.8 & 58.5 \\
\hline Sugar & 28.9 & 33.2 & 39.1 & 16.2 \\
\hline Cigars and cigarettes & 24.4 & 30.8 & 107.8 & 120.0 \\
\hline Electricity & 17.2 & 14.4 & 26.8 & 25.7 \\
\hline Wheat and flour & 12.9 & 49.6 & 37.1 & 26.5 \\
\hline Beer & 7.1 & $\ldots$ & $\ldots$ & $\ldots$ \\
\hline Wheat and rye byproducts & 7.1 & 63.7 & 57.2 & 31.8 \\
\hline Sunflower and cotton oil & 6.8 & $\ldots$ & $\ldots$ & $\ldots$ \\
\hline Poultry products & 5.3 & $\ldots$ & $\ldots$ & $\ldots$ \\
\hline Medicine & $\ldots$ & 14.6 & 35.9 & 36.3 \\
\hline Coffee and coffee substitute & $\ldots$ & 11.6 & $\ldots$ & $\ldots$ \\
\hline Radio receiver & $\ldots$ & 6.8 & $\ldots$ & $\ldots$ \\
\hline Automobiles & $\ldots$ & $\ldots$ & 45.3 & 65.2 \\
\hline Electronic devices & $\ldots$ & $\ldots$ & 17.6 & 20.2 \\
\hline Pipes and other related products & $\ldots$ & $\cdots$ & $\cdots$ & 16.2 \\
\hline Total & 298.2 & 472.6 & 594.8 & 546.9 \\
\hline As a percent of total imports & 75.3 & 68.8 & 63.0 & 61.8 \\
\hline \multicolumn{5}{|l|}{ Memorandum item: } \\
\hline Total imports & 396.2 & 686.8 & 943.5 & 884.3 \\
\hline
\end{tabular}

Source: Georgian State Department of Statistics.

1/ The analysis is based on raw data provided by the State Department of Statistics, Tbilisi, Georgia. Data on imports differs significantly from staff estimates in the balance of payments table. This is because the official balance of payments statistics are weak, with significant under reporting and under valuation of imports. 
Table 36. Georgia: Extemal Debt Outstanding, 1995-99

(In millions of U.S. dollars)

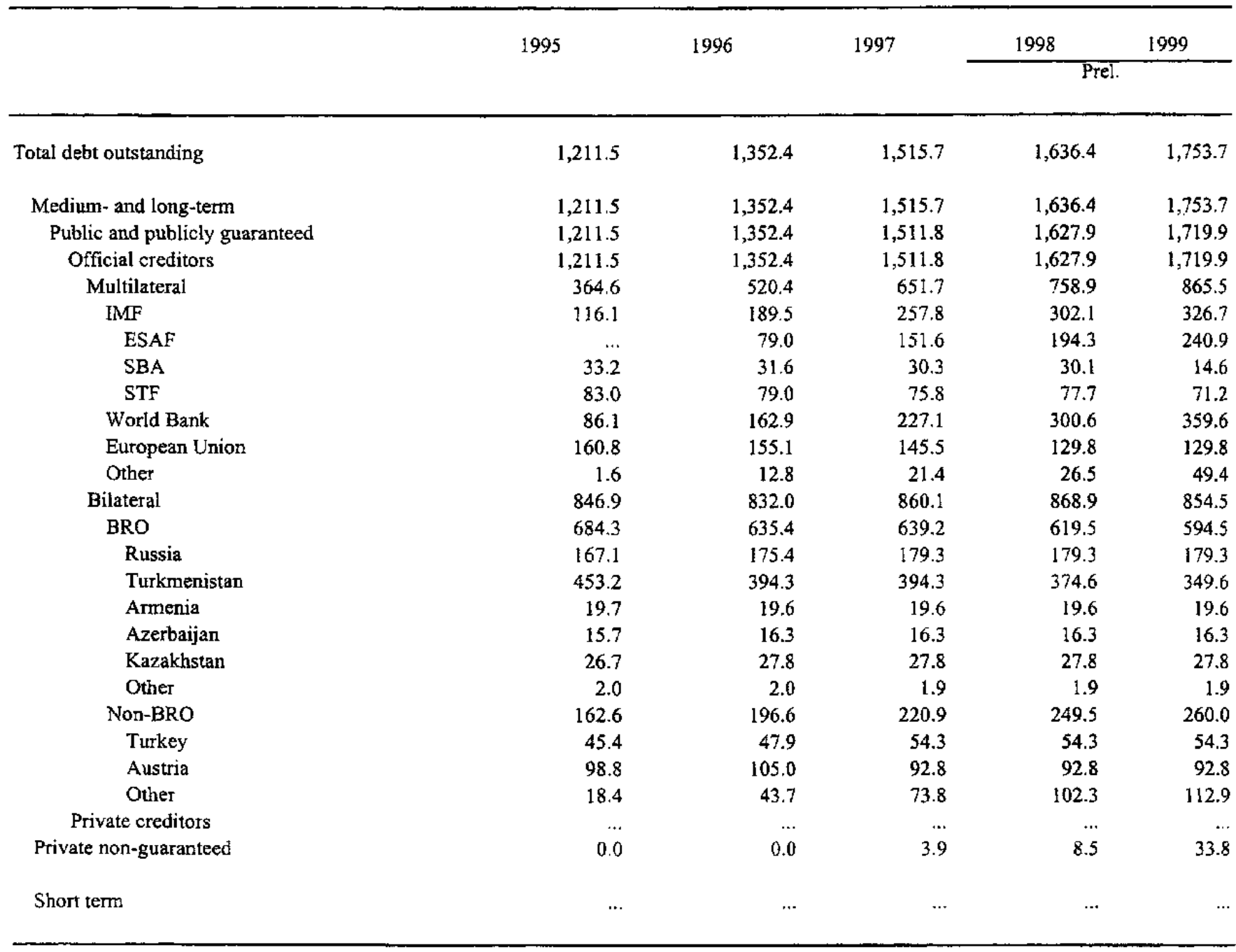

Sources: Georgian authorities; and Fund staff estimates. 


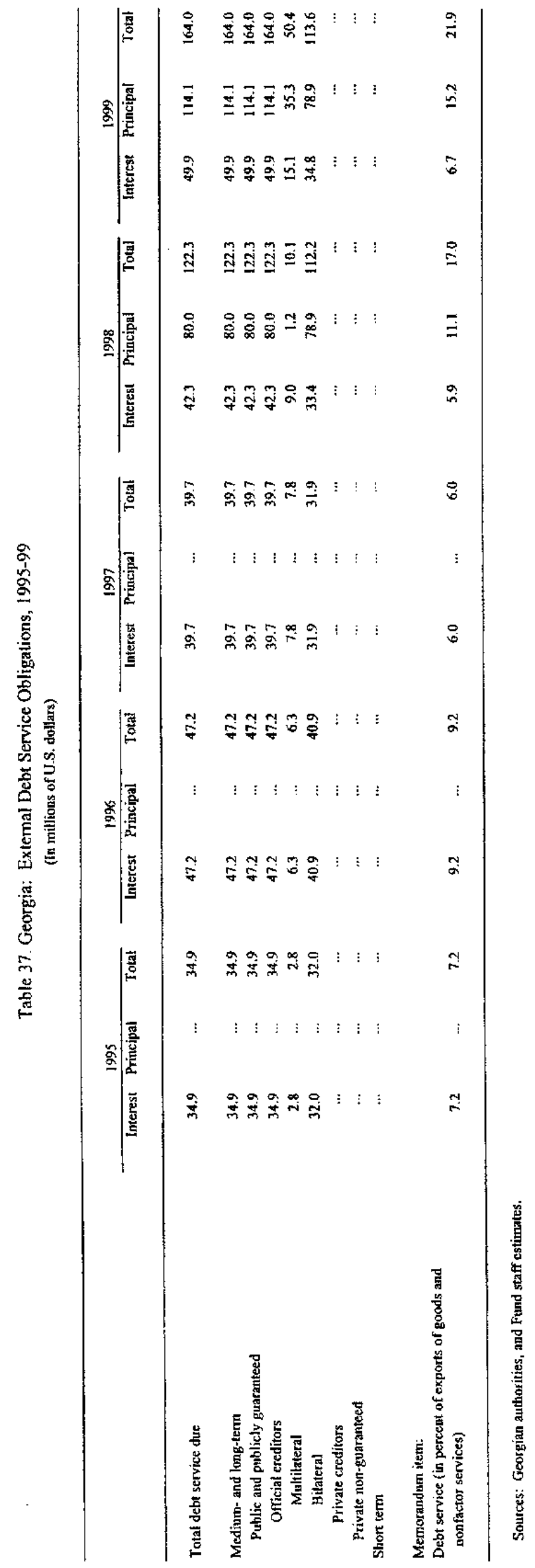


Table 38. Georgia: Exchange Rates, 1995-99 1/

\begin{tabular}{|c|c|c|c|c|c|c|}
\hline \multirow[t]{2}{*}{ - } & \multicolumn{2}{|c|}{ Lari per U.S. dollar } & \multicolumn{2}{|c|}{ Lari per thousands of ruble } & \multirow{2}{*}{$\frac{\text { NEER } 2 i}{\text { End-of-period }}$} & \multirow{2}{*}{$\frac{\text { REER 2/ }}{\text { End-of-period }}$} \\
\hline & Period average & End-of-period & Period average & End-of-period & & \\
\hline $1995 \mathrm{Q1}$ & 1.294 & 1.300 & 0.280 & 0.250 & 98.2 & 97.0 \\
\hline Q2 & 1.300 & 1.300 & 0.250 & 0.240 & 98.8 & 90.5 \\
\hline Q3 & 1.300 & 1.300 & 0.250 & 0.250 & 100.0 & 92.5 \\
\hline Q4 & 1.258 & 1.230 & 0.250 & 0.250 & 108.6 & 118.4 \\
\hline Year & 1.288 & 1.230 & 0.258 & 0.250 & 108.6 & 118.4 \\
\hline 1996 Q1 & 1.252 & 1.262 & 0.240 & 0.250 & 112.5 & 125.6 \\
\hline Q2 & 1.259 & 1.255 & 0.220 & 0.220 & 117.2 & 129.1 \\
\hline Q3 & 1.265 & 1.270 & 0.230 & 0.230 & 119.5 & 126.2 \\
\hline Q4 & 1.275 & 1.274 & 0.220 & 0.220 & 123.2 & 127.2 \\
\hline Year & 1.263 & 1.274 & 0.228 & 0.220 & 123.2 & 127.2 \\
\hline 1997 Q1 & 1.298 & 1.294 & 0.220 & 0.220 & 130.7 & 131.7 \\
\hline Q2 & 1.299 & 1.300 & 0.220 & 0.230 & 134.4 & 129.2 \\
\hline Q3 & 1.295 & 1.298 & 0.220 & 0.220 & 140.2 & 130.1 \\
\hline Q4 & 1.308 & 1.304 & 0.220 & 0.220 & 141.7 & 130.6 \\
\hline Year & 1.300 & 1.304 & 0.220 & 0.220 & 141.7 & 130.6 \\
\hline 1998 Q1 & 1.327 & 1.335 & 0.220 & 0.219 & 145.6 & 130.0 \\
\hline $\mathrm{Q} 2$ & 1.342 & 1.348 & 0.218 & 0.217 & 146.9 & 125.1 \\
\hline Q3 & 1.350 & 1.364 & 0.169 & 0.085 & 179.3 & 134.0 \\
\hline Q4 & 1.544 & 1.790 & 0.086 & 0.086 & 148.1 & 119.1 \\
\hline Year & 1.391 & 1.790 & 0.173 & 0.086 & 148.1 & 119.1 \\
\hline 1999 Q1 & 2.199 & 2.215 & 0.094 & 0.090 & 330.1 & 108.3 \\
\hline Q2 & 2.059 & 1.940 & 0.083 & 0.080 & 155.9 & 121.9 \\
\hline Q3 & 1.875 & 1.850 & 0.075 & 0.073 & 172.0 & 127.8 \\
\hline $\mathrm{Q} 4$ & 1.951 & 1.960 & 0.074 & 0.071 & 172.1 & 127.7 \\
\hline Year & 2.021 & 1.960 & 0.082 & 0.071 & 172.1 & 127.7 \\
\hline
\end{tabular}

Sources: National Bank of Georgia; IMF, Information Notice System; and Fund staff estimates.

1/ Lari exchange rates are those prevailing on the Tbilisi Interbank Curtency Exchange (TICEX).

$2 /$ Nominal effective exchange rate and real effective exchange rate. Index, 1995=100. Increase incicates appreciation. 